\title{
MAJOR OIL PLAYS IN UTAH \\ AND VICINITY
}

\author{
QUARTERLY \\ TECHNICAL PROGRESS REPORT
}

\author{
Reporting Period \\ Start Date: October 1, 2003 \\ End Date: December 31, 2003
}

\begin{abstract}
by
Thomas C. Chidsey, Jr., Principal Investigator/Program Manager, Craig D. Morgan, Kevin McClure, Douglas A. Sprinkel, Roger L. Bon, and Hellmut H. Doelling

Utah Geological Survey

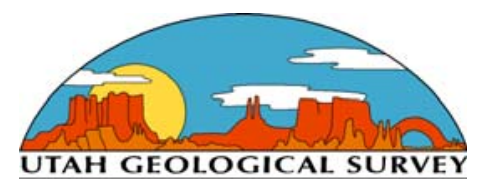

March 2004

Contract No. DE-FC26-02NT15133
\end{abstract}

Submitting Organization: Utah Geological Survey

1594 West North Temple, Suite 3110

P.O. Box 146100

Salt Lake City, Utah 84114-6100

Ph.: (801) 537-3300/Fax: (801) 537-3400

Rhonda Jacobs, Contract Manager

U.S. Department of Energy

National Petroleum Technology Office

1 West $3^{\text {rd }}$ Street

Tulsa, OK 74103-3532 


\section{DISCLAIMER}

This report was prepared as an account of work sponsored by an agency of the United States Government. Neither the United States Government nor any agency thereof, nor any of their employees, makes any warranty, express or implied, or assumes any legal liability or responsibility for the accuracy, completeness, or usefulness of any information, apparatus, product, or process disclosed, or represents that its use would not infringe privately owned rights. Reference herein to any specific commercial product, process, or service by trade name, trademark, manufacturer, or otherwise does not necessarily constitute or imply its endorsement, recommendation, or favoring by the United States Government or any agency thereof. The views and opinions of authors expressed herein do not necessarily state or reflect those of the United States Government or any agency thereof.

Although this product represents the work of professional scientists, the Utah Department of Natural Resources, Utah Geological Survey, makes no warranty, expressed or implied, regarding its suitability for a particular use. The Utah Department of Natural Resources, Utah Geological Survey, shall not be liable under any circumstances for any direct, indirect, special, incidental, or consequential damages with respect to claims by users of this product. 


\title{
MAJOR OIL PLAYS IN UTAH \\ AND VICINITY
}

\author{
QUARTERLY \\ TECHNICAL PROGRESS REPORT
}

Reporting Period

Start Date: October 1, 2003

End Date: December 31, 2003

by

Thomas C. Chidsey, Jr., Principal Investigator/Program Manager, Craig D. Morgan, Kevin McClure, Douglas A. Sprinkel, Roger L. Bon, and Hellmut H. Doelling

Utah Geological Survey

\section{March 2004}

\section{Contract No. DE-FC26-02NT15133}

Submitting Organization: Utah Geological Survey

1594 West North Temple, Suite 3110

P.O. Box 146100

Salt Lake City, Utah 84114-6100

Ph.: (801) 537-3300/Fax: (801) 537-3400

\author{
Rhonda Jacobs, Contract Manager \\ U.S. Department of Energy \\ National Petroleum Technology Office \\ 1 West $3^{\text {rd }}$ Street \\ Tulsa, OK 74103-3532
}

US/DOE Patent Clearance is not required prior to the publication of this document. 


\section{ABSTRACT}

Utah oil fields have produced over 1.2 billion barrels $\left(191\right.$ million $\left.\mathrm{m}^{3}\right)$. However, the 13.7 million barrels $\left(2.2\right.$ million $\mathrm{m}^{3}$ ) of production in 2002 was the lowest level in over 40 years and continued the steady decline that began in the mid-1980s. The Utah Geological Survey believes this trend can be reversed by providing play portfolios for the major oil-producing provinces (Paradox Basin, Uinta Basin, and thrust belt) in Utah and adjacent areas in Colorado and Wyoming. Oil plays are geographic areas with petroleum potential caused by favorable combinations of source rock, migration paths, reservoir rock characteristics, and other factors. The play portfolios will include: descriptions and maps of the major oil plays by reservoir; production and reservoir data; case-study field evaluations; locations of major oil pipelines; identification and discussion of land-use constraints; descriptions of reservoir outcrop analogs; and summaries of the state-of-the-art drilling, completion, and secondary/tertiary techniques for each play.

This report covers research activities for the sixth quarter of the project (October 1 through December 31, 2003). This work included describing outcrop analogs for the Jurassic Twin Creek Limestone and Mississippian Leadville Limestone, major oil producers in the thrust belt and Paradox Basin, respectively, and analyzing best practices used in the southern Green River Formation play of the Uinta Basin.

Production-scale outcrop analogs provide an excellent view of reservoir petrophysics, facies characteristics, and boundaries contributing to the overall heterogeneity of reservoir rocks. They can be used as a "template" for evaluation of data from conventional core, geophysical and petrophysical logs, and seismic surveys. In the Utah/Wyoming thrust belt province, the Jurassic Twin Creek Limestone produces from subsidiary closures along major ramp anticlines where the low-porosity limestone beds are extensively fractured and sealed by overlying argillaceous and non-fractured units. The best outcrop analogs for Twin Creek reservoirs are found at Devils Slide and near the town of Peoa, Utah, where fractures in dense, homogeneous non-porous limestone beds are in contact with the basal siltstone units (containing sealed fractures) of the overlying units. The shallow marine, Mississippian Leadville Limestone is a major oil and gas reservoir in the Paradox Basin of Utah and Colorado. Hydrocarbons are produced from basement-involved, northwest-trending structural traps with closure on both anticlines and faults. Excellent outcrops of Leadville-equivalent rocks are found along the south flank of the Uinta Mountains, Utah. For example, like the Leadville, the Mississippian Madison Limestone contains zones of solution breccia, fractures, and facies variations. When combined with subsurface geological and production data, these outcrop analogs can improve (1) development drilling and production strategies such as horizontal drilling, (2) reservoir-simulation models, (3) reserve calculations, and (4) design and implementation of secondary/tertiary oil recovery programs and other best practices used in the oil fields of Utah and vicinity.

In the southern Green River Formation play of the Uinta Basin, optimal drilling, development, and production practices consist of: (1) owning drilling rigs and frac holding tanks; (2) perforating sandstone beds with more than 8 percent neutron porosity and stimulate with separate fracture treatments; (3) placing completed wells on primary production using artificial lift; (4) converting wells relatively soon to secondary waterflooding maintaining reservoir pressure above the bubble point to maximize oil recovery; (5) developing waterflood units using an alternating injector - producer pattern on 40-acre (16-ha) spacing; and (6) 
recompleting producing wells by perforating all beds that are productive in the waterflood unit.

As part of technology transfer activities during this quarter, an abstract describing outcrop reservoir analogs was accepted by the American Association of Petroleum Geologists, for presentation at the 2004 annual meeting in Dallas, Texas. Another abstract was submitted for consideration on basin-wide correlation of Green River Formation plays and subplays in the Uinta Basin in Utah. The project home page was updated on the Utah Geological Survey Internet web site. 


\section{CONTENTS}

ABSTRACT

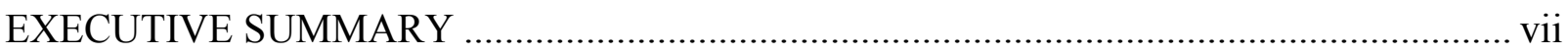

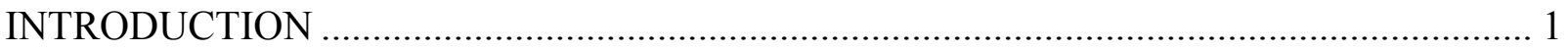

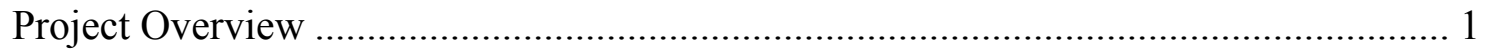

Project Benefits ………………………………................................................. 1

OUTCROP RESERVOIR ANALOGS - DISCUSSION AND RESULTS ……………........... 3

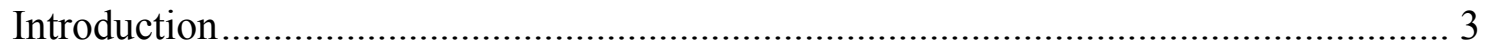

Thrust Belt Province ………………......................................................................... 4

Twin Creek Limestone Reservoir ..................................................................... 5

Twin Creek Limestone Outcrop Analogs, Devils Slide and Peoa, Utah .............. 6

Gypsum Spring Member....................................................................... 8

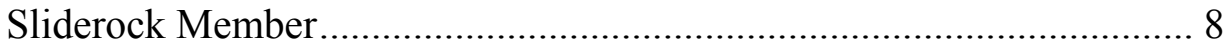

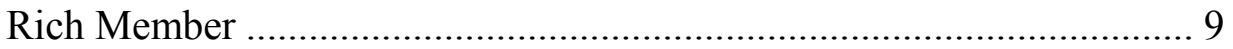

Boundary Ridge Member..................................................................... 9

Watton Canyon Member...................................................................... 9

Leeds Creek Member........................................................................... 11

Giraffe Creek Member....................................................................... 11

Paradox Basin Province ....................................................................................... 11

Leadville Limestone Reservoir ........................................................................ 14

Leadville Limestone Outcrop Analogs, South Flank of the Uinta Mountains,

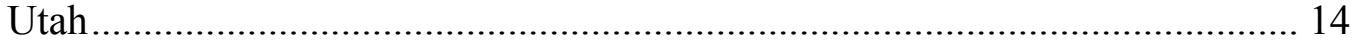

BEST PRACTICES, SOUTHERN GREEN RIVER FORMATION PLAY, UINTA BASIN -

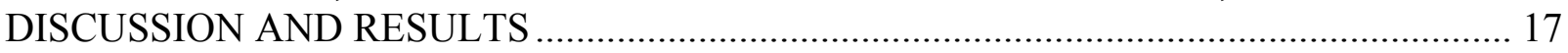

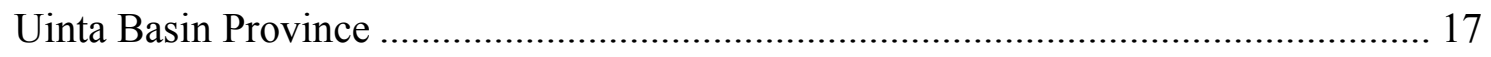

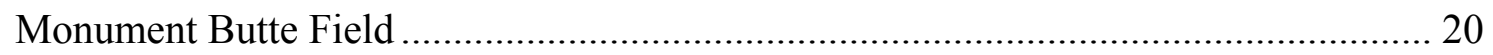

Optimal Drilling, Development, and Production Practices .......................................... 20

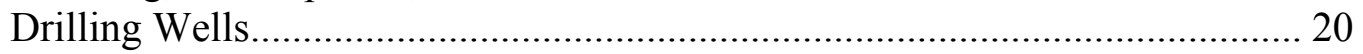

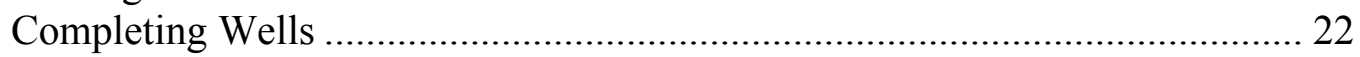

Producing Wells and Waterflood Programs ....................................................... 22

Travis waterflood unit......................................................................... 23

Monument Butte Northeast waterflood unit .......................................... 24

Beluga waterflood unit........................................................................ 26

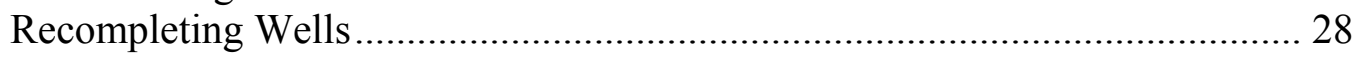

Environmental Issues ………………………………….............................. 29

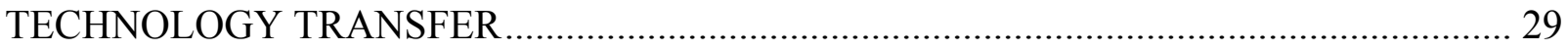

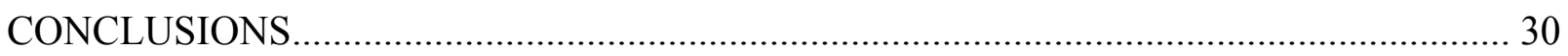

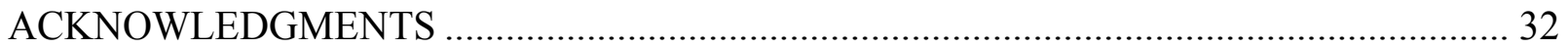


APPENDIX A - Twin Creek Limestone, Devils Slide Measured Section ................................ A-1 APPENDIX B - Twin Creek Limestone, Peoa Measured Section............................................ B-1 


\section{FIGURES}

Figure 1. Major oil-producing provinces of Utah and vicinity - (A) Paradox Basin, (B) Uinta Basin, (C) Utah-Wyoming thrust belt ........................................................... 2

Figure 2. Location of Jurassic Twin Creek Limestone play and fields, Utah and Wyoming ..... 4

Figure 3. A - Stratigraphic column of a portion of the Mesozoic section, including members of the Jurassic Twin Creek Limestone, exposed in Weber Canyon near Devils Slide, Morgan and Summit Counties, Utah, and B - typical gamma ray-resistivity log of the Twin Creek Limestone, Anschutz Ranch field discovery well, Summit County, Utah .. 5

Figure 4. Geologic map of the Devils Slide area, Morgan and Summit Counties, Utah, showing the location of the stratigraphic measured section through the Twin Creek Limestone.. 7

Figure 5. Geologic map of the Peoa area, Summit County, Utah, showing the location of the stratigraphic measured section through the Twin Creek Limestone............................. 7

Figure 6. Fracture planes generated by four orientations of the three principal stresses during folding of sedimentary rocks

Figure 7. Devils Slide, composed of the Rich Member of the Twin Creek Limestone, Weber Canyon......

Figure 8. Characteristics of the Rich Member of the Twin Creek Limestone; A - current ripples; $\mathrm{B}$ and $\mathrm{C}$ - rhombic fracture patterns; D - closely spaced rectilinear fracturing; $\mathrm{E}$ pencil weathering; and F - contact between fractured Rich Member limestone and basal siltstone of the overlying Boundary Ridge Member.....

Figure 9. Characteristics of the Watton Canyon Member of the Twin Creek Limestone; A closely spaced rectilinear fracturing in micritic limestone; B - large-scale rectilinear fracturing in steeply dipping limestone; $\mathrm{C}$ - large-scale, open fractures on bedding plane surface; D - rectilinear fracturing on top of the Watton Canyon; E - contact between fractured Watton Canyon Member limestone and basal argillaceous unit of the overlying Leeds Creek Member; and F - heterogeneity within the Watton Canyon caused be thinbedded siltsone

Figure 10. Field locations and thickness for Mississippian Leadville Limestone, Utah and Colorado.

Figure 11. A - Stratigraphic column of a portion of the Paleozoic section from subsurface well data, Grand and San Juan Counties, and B - typical gamma ray-sonic log of the Leadville Limestone, Lisbon field discovery well, San Juan County, Utah 15

Figure 12. A - Location of Mississippian rock outcrops in Utah equivalent to the Leadville Limestone, and B - stratigraphic column of a portion of the Paleozoic section along the south flank of the Uinta Mountains

Figure 13. Mississippian Deseret Limestone, North Fork Canyon of the Duchesne River, Duchesne County, Utah 17

Figure 14. Characteristics of the Mississippian Madison Limestone along the south flank of the Uinta Mountains, Utah; A - typical limestone and dolomite units containing fractures, stylolites, and crinoid hash; B - vugs and fractures in limestone and dolomitic units; C close-up of open and calcite-filled vugs; D - close-up of small-scale fractures; E heterogeneity in stratigraphic section; and F - carbonate buildup or mud mound ............ 18

Figure 15. Diagrams showing the generalized depositional setting for Lake Uinta during high lake levels (A) and low lake levels (B) 
Figure 16. Structure map on top of the lower member of the Green River Formation, Greater Monument Butte field area, Duchesne and Uintah Counties, Utah

Figure 17. Combined structure and isopach map for the Travis reservoir, Travis waterflood

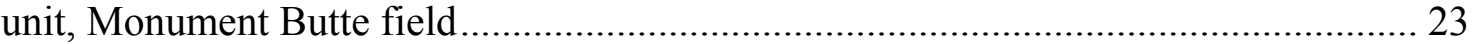

Figure 18. West-to-east cross section of the Travis interval in the Travis waterflood unit...... 24

Figure 19. Monthly oil and gas produced in the Travis waterflood unit ............................... 25

Figure 20. Combined top of the MGR 7 marker structure and MGR 7b sandstone isopach map, Monument Butte Northeast waterflood unit, Monument Butte field........................... 25

Figure 21. West-to-east cross section of the Monument Butte interval in the Monument Butte

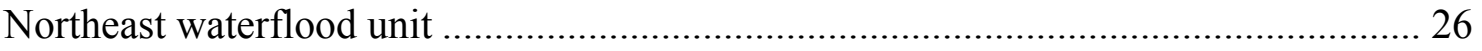

Figure 22. Monthly oil and gas produced in the Monument Butte Northeast waterflood unit. 27

Figure 23. Combined top of the MGR 12 marker structure and MGR 13 log cycle isopach map, Beluga waterflood unit, Monument Butte field

Figure 24. West-to-east cross section of the MGR 13 log-cycle in the Beluga interval, Beluga waterflood unit ........................................................................................... 28

Figure 25. Monthly oil and gas produced in the Beluga waterflood unit ............................ 29 


\section{EXECUTIVE SUMMARY}

Utah oil fields have produced over 1.2 billion barrels $\left(191\right.$ million $\left.\mathrm{m}^{3}\right)$. However, the 13.7 million barrels $\left(2.2\right.$ million $\mathrm{m}^{3}$ ) of production in 2002 was the lowest level in over 40 years and continued the steady decline that began in the mid-1980s. The overall objectives of this study are to: (1) increase recoverable oil from existing field reservoirs, (2) add new discoveries, (3) prevent premature abandonment of numerous small fields, (4) increase deliverability through identifying the latest drilling, completion, and secondary/tertiary techniques, and (5) reduce development costs and risk.

To achieve these objectives, the Utah Geological Survey is producing play portfolios for the major oil-producing provinces (Paradox Basin, Uinta Basin, and thrust belt) in Utah and adjacent areas in Colorado and Wyoming. This research is funded by the Preferred Upstream Management Program (PUMPII) of the U.S. Department of Energy, National Petroleum Technology Office (NPTO) in Tulsa, Oklahoma. This report covers research activities for the sixth quarter of the project (October 1 through December 31, 2003). This work included: (1) describing outcrop analogs to the Jurassic Twin Creek Limestone (thrust belt) and Mississippian Leadville Limestone (Paradox Basin), (2) analyzing best practices used in the southern Green River Formation play of the Uinta Basin, and (3) technology transfer activities.

Utah is fortunate in that it has representative outcrop analogs for each major oil play. Production-scale outcrop analogs provide an excellent view, often in three dimensions, of reservoir petrophysics, facies characteristics, and boundaries contributing to the overall heterogeneity of reservoir rocks. Outcrop analogs can be used as a "template" for evaluation of data from conventional core, geophysical and petrophysical logs, and seismic surveys. When combined with subsurface geological and production data, outcrop analogs can improve development drilling and production strategies, reservoir-simulation models, reserve calculations, and design and implementation of secondary/tertiary oil recovery programs and other best practices used in the oil fields of Utah and vicinity.

One of the most prolific oil reservoirs in the Utah/Wyoming thrust belt province is the Jurassic Twin Creek Limestone that was deposited in a shallow-water embayment south of the main body of a Middle Jurassic sea. Traps form on discrete subsidiary closures along major ramp anticlines where the low-porosity Twin Creek is extensively fractured. The seals for the producing horizons are the overlying argillaceous and clastic beds, and non-fractured units within the Twin Creek Limestone. Most oil and gas production is from perforated intervals in the Watton Canyon, upper Rich, and Sliderock Members. The best outcrop analogs for Twin Creek reservoirs are found at Devils Slide and near the town of Peoa, Utah. Closely spaced rhombic and rectilinear fracture patterns developed on bedding planes and within dense, homogeneous non-porous (in terms of primary porosity) limestone beds of the Rich and Watton Canyon Members. The reservoir's upper contact with the basal siltstone units (where fractures are sealed) of the overlying members set up the Rich and Watton Canyon for hydrocarbon trapping and production. Thin-bedded siltstone within the Rich and Watton Canyon Members, also observed in outcrop, creates additional reservoir heterogeneity. Identification and correlation of these barriers and baffles to fluid flow, and recognition of fracture set orientations in individual Twin Creek reservoirs is critical to understanding the effects of these parameters on production rates, petroleum movement pathways, and horizontal well plans.

The Mississippian Leadville Limestone is a major oil and gas reservoir in the Paradox Basin of Utah and Colorado. The Leadville was deposited on a shallow, open-marine, 
carbonate shelf. Hydrocarbons are produced from basement-involved, northwest-trending structural traps with closure on both anticlines and faults. Three factors create reservoir heterogeneity within productive zones: (1) variations in carbonate fabrics and facies; (2) diagenesis (including karstification); and (3) fracturing. Excellent outcrops of Leadvilleequivalent rocks are found along the south flank of the Uinta Mountains, Utah. They provide production-scale analogs displaying the facies characteristics, geometry, distribution, and the nature of boundaries which contribute to the overall heterogeneity of Leadville reservoir rocks. For example, the Madison Limestone is a fine to coarse crystalline, cherty limestone with some dolomite. Limestone units commonly contain numerous caverns, sinkholes, and local zones of solution breccia and vugs. Some sections can have high heterogeneity due to development of stylolites, jointing, and fractures. Elsewhere, possible carbonate buildups or mud mounds are also found in the Madison.

Over 125 fields have been discovered in Utah's major oil provinces with production from 4,300-plus wells. Best practices used in these fields include waterflood, carbon-dioxide flood, gas injection, and horizontal drilling. In the southern Green River Formation play of the Uinta Basin, production and ultimate recovery from the waterflood units in the greater Monument Butte field area are enhanced by the following drilling, development, and production practices: (1) use operator-owned drilling rigs to ensure availability and lower costs compared with contracting; (2) use operator-owned frac holding tanks to reduce the cost of the fracture treatments; (3) select sandstone beds with more than 8 percent neutron porosity for perforation and stimulate each bed with separate fracture treatments beginning with the lowermost perforated bed; (4) use artificial lift for wells on primary production; (5) convert wells relatively soon to secondary waterflooding to maintain reservoir pressure above the bubble point to maximize oil recovery; (6) develop waterflood units using an alternating injector - producer pattern on 40-acre (16-ha) spacing; (7) recomplete producing wells by perforating all beds that are productive in the waterflood unit; (8) hire people who can work closely with the regulatory agencies involved; and (9) maintain several drilling options so if environmental issues delay some parts, there are other drilling activities that can be pursued.

As part of technology transfer activities during this quarter, an abstract describing reservoir outcrop analogs was accepted by the American Association of Petroleum Geologists, for presentation at the 2004 annual meeting in Dallas, Texas. Another abstract was submitted for consideration on basin-wide correlation of Green River Formation plays and subplays in the Uinta Basin in Utah. The project home page was also updated on the Utah Geological Survey Internet web site. 


\section{INTRODUCTION}

\section{Project Overview}

Utah oil fields have produced over 1.2 billion barrels (bbls) (191 million $\mathrm{m}^{3}$ ) (Utah Division of Oil, Gas and Mining, 2003). However, the 13.7 million bbls $\left(2.2\right.$ million $\left.\mathrm{m}^{3}\right)$ of production in 2002 was the lowest level in over 40 years and continued the steady decline that began in the mid-1980s (Utah Division of Oil, Gas and Mining, 2002a). Proven reserves are relatively high, at 283 million bbls (45 million $\mathrm{m}^{3}$ ) (Energy Information Administration, 2001). With higher oil prices now prevailing, secondary and tertiary recovery techniques should boost future production rates and ultimate recovery from known fields.

Utah's drilling history has fluctuated greatly due to discoveries, oil price trends, and changing exploration targets. During the boom period of the early 1980s, activity peaked at over 500 wells per year. Sustained high petroleum prices are likely to provide the economic climate needed to entice less high-risk exploration investments (more wildcats), resulting in new discoveries.

Utah still contains large areas that are virtually unexplored. There is also significant potential for increased recovery from existing fields by employing improved reservoir characterization and the latest drilling, completion, and secondary/tertiary technologies. New exploratory targets may be identified from three-dimensional (3D) seismic surveys. Development of potential prospects is within the economic and technical capabilities of both major and independent operators.

The primary goal of this study is to increase recoverable oil reserves from existing field reservoirs and new discoveries by providing play portfolios for the major oil-producing provinces (Paradox Basin, Uinta Basin, and thrust belt) in Utah and adjacent areas in Colorado and Wyoming (figure 1). These play portfolios will include: descriptions (such as stratigraphy, diagenetic analysis, tectonic setting, reservoir characteristics, trap type, seal, and hydrocarbon source) and maps of the major oil plays by reservoir; production and reservoir data; case-study field evaluations; summaries of the state-of-the-art drilling, completion, and secondary/tertiary techniques for each play; locations of major oil pipelines; and descriptions of reservoir outcrop analogs for each play. Also included will be an analysis of land-use constraints to development, such as wilderness or roadless areas, and national parks within oil plays.

\section{Project Benefits}

The overall goal of this multi-year project is enhanced petroleum production in the Rocky Mountain region. Specifically, the project goal will benefit from the following projects:

(1) improved reservoir characterization to prevent premature abandonment of numerous small fields in the Paradox and Uinta Basins,

(2) identification of the type of untapped compartments created by reservoir heterogeneity (for example, diagenesis and rapid facies changes) to increase recoverable reserves, 


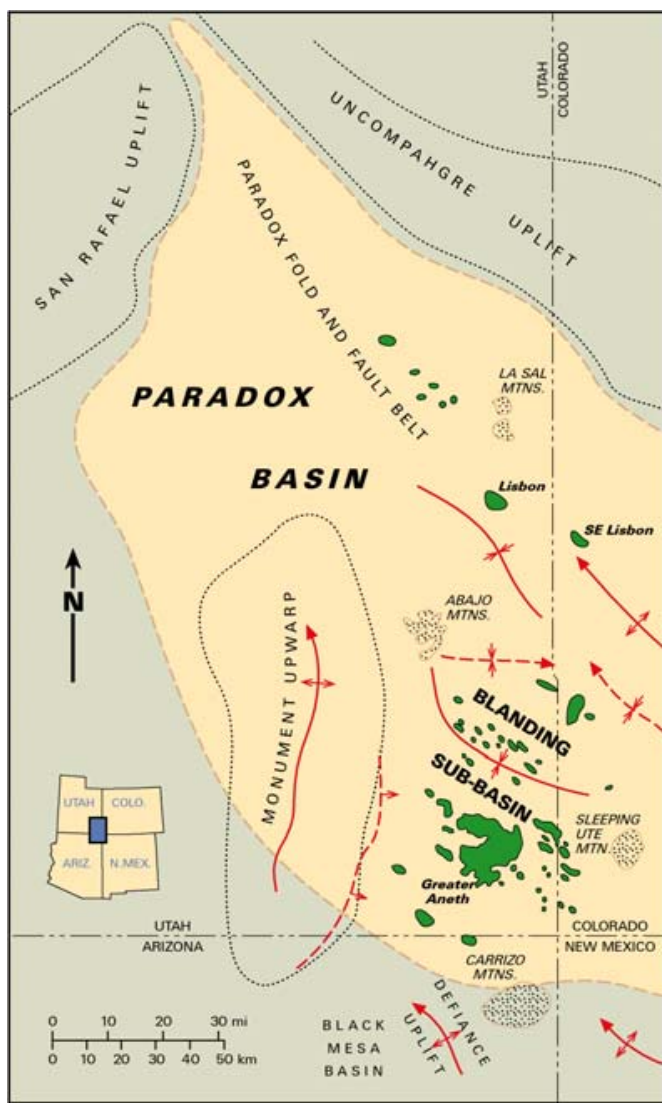

A

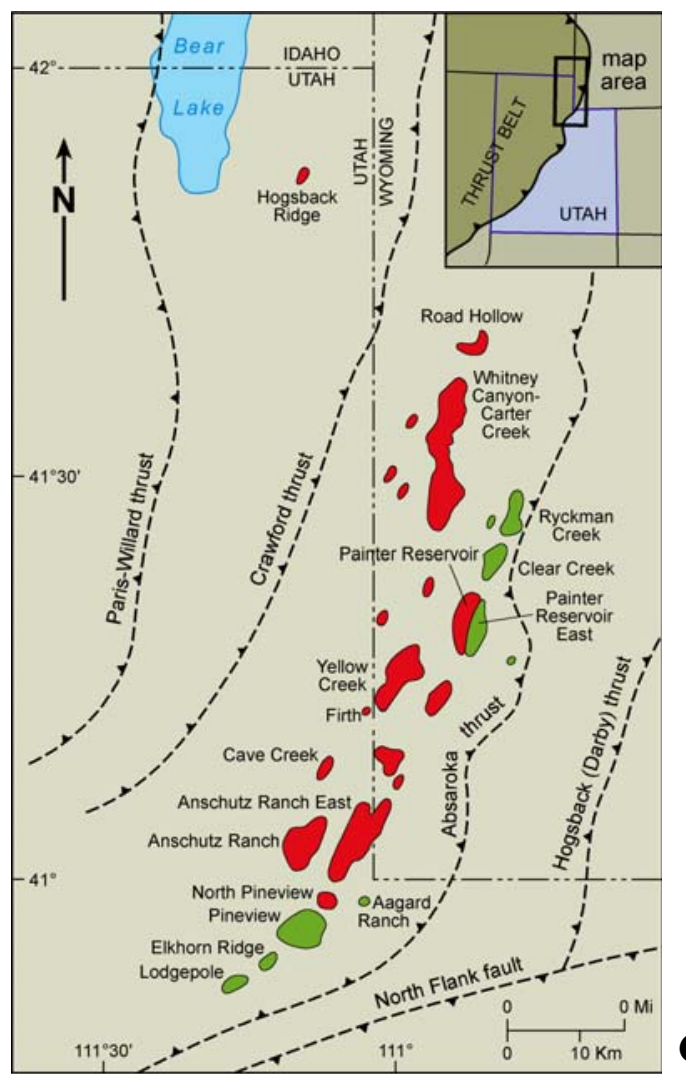

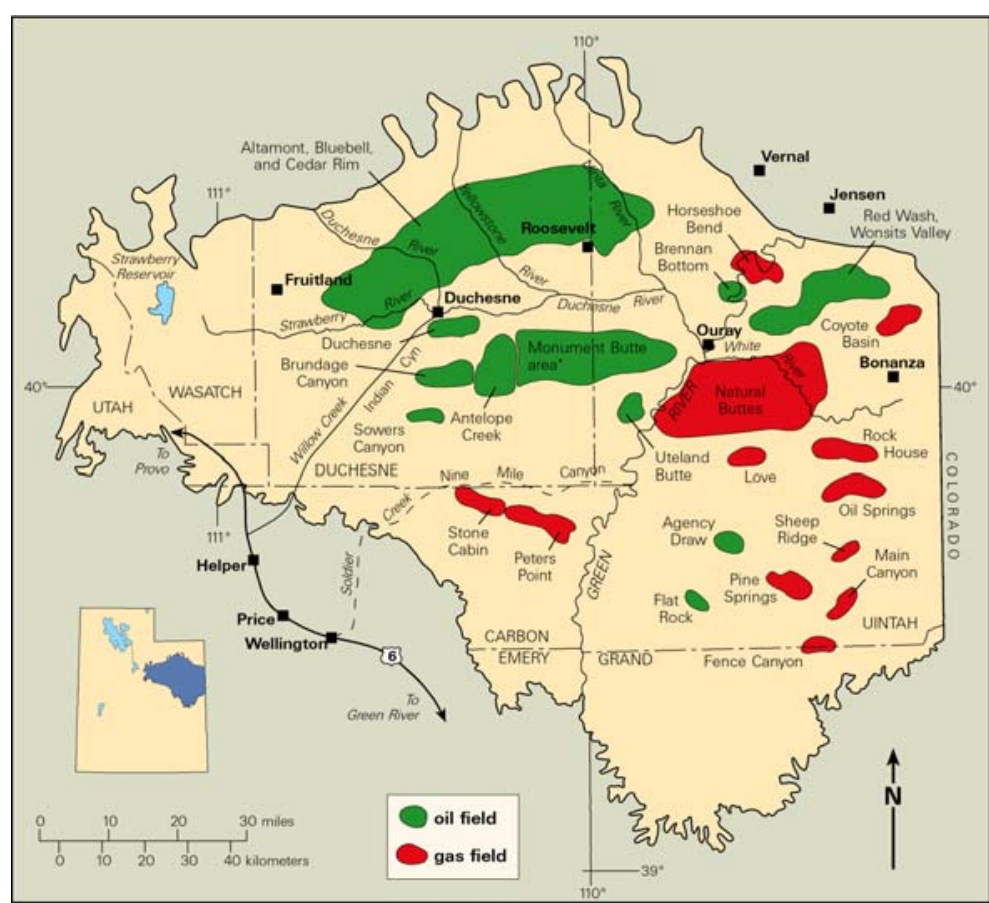

B

Figure 1. Major oil-producing provinces of Utah and vicinity. A - Oil and gas fields in the Paradox Basin of Utah and Colorado. B - Oil and gas fields in the Uinta Basin of Utah. C - Oil and gas fields, uplifts, and major thrust faults in the Utah-Wyoming thrust belt. 
(3) identification of the latest drilling, completion, and secondary/tertiary techniques to increase deliverability,

(4) identification of reservoir trends for field extension drilling and stimulating exploration in undeveloped parts of producing fairways,

(5) identification of technology used in other identified basins or trends with similar types of reservoirs that might improve production in Utah,

(6) identification of optimal well spacing/location to reduce the number of wells needed to successfully drain a reservoir to reduce development costs and risk, and allow limited energy investment dollars to be used more productively, and

(7) technology transfer to encourage new development and exploration efforts and increase royalty income to the federal, state, local, Native American, and fee owners.

The Utah play portfolios produced by this project will provide an easy-to-use geologic, engineering, and geographic reference to help petroleum companies plan exploration and landacquisition strategies. These portfolios may also help pipeline companies plan future facilities and pipelines. Other users of the portfolios will include petroleum engineers, petroleum land specialists, landowners, bankers and investors, economists, utility companies, manufacturers, county planners, and numerous government agencies.

The results of this project will be transferred to industry and other interested parties through establishment of Technical Advisory and Stake Holder Boards, an industry outreach program, and technical presentations at national and regional professional meetings. All of this information will be made public through: (1) the Utah Geological Survey (UGS) Internet web site; (2) an interactive, menu-driven digital product on compact disc; and (3) hard copy publications in various technical or trade journals.

\section{OUTCROP RESERVOIR ANALOGS - DISCUSSION AND RESULTS}

\section{Introduction}

Utah is fortunate in that representative outcrop analogs (depositional or structural) for each major oil play are present in or near the thrust belt, Uinta Basin, and Paradox Basin. Production-scale analogs provide an excellent view, often in 3D, of reservoir petrophysics, facies characteristics, geometry, distribution, and the nature of boundaries contributing to the overall heterogeneity of reservoir rocks. The specific objectives of this work are to: (1) increase understanding of vertical and lateral petrophysical and facies variations within major reservoirs; (2) describe the lithologic characteristics; (3) determine the morphology, internal geometries, and possible permeability and porosity distributions; and (4) identify potential impediments and barriers to fluid flow.

An outcrop-analog model, combined with the details of internal lithofacies characteristics, can be used as a "template" for evaluation of data from conventional core, geophysical and petrophysical logs, and seismic surveys. When combined with subsurface 
geological and production data, the analog model will improve development drilling and production strategies, reservoir-simulation models, reserve calculations, and design and implementation of secondary/tertiary oil recovery programs and other best practices used in the oil fields of Utah and vicinity. Outcrop analogs for the major oil reservoirs in the thrust belt and Paradox Basin are presented in the following sections.

\section{Thrust Belt Province}

The Utah-Wyoming-Idaho salient of the Cordilleran thrust belt is defined as the region north of the Uinta Mountains of northeastern Utah and south of the Snake River Plain of Idaho, with the Green River basin of Wyoming forming the eastern boundary. Thrusting extends westward into the Great Basin for more than 100 miles $(160 \mathrm{~km})$. There are four major thrust faults in the region (from west to east): the Paris-Willard, Crawford, Absaroka, and Hogsback (Darby). These thrust faults represent detached (not involving basement rock), compressional styles of deformation. The thrusts generally trend in a northnortheast direction. The leading edges of these faults are listric in form and structurally complex, with numerous folds and thrust splays. The Absaroka thrust moved in Late Cretaceous time (pre-mid-Santonian to pre-CampanianMaestrichtian according to Royse and others, 1975). Most thrust belt oil fields are on the Absaroka thrust plate (figure 1C).

Petroleum-trapping mechanisms in Mesozoic-cored structures of the Absaroka thrust consist of long, narrow, doubly plunging anticlines. These anticlines are asymmetric, overturned to the east, and often have en echelon structures along the leading edge of the Absaroka thrust. Traps form on discrete subsidiary closures along major ramp anticlines. A prolific oil and gas reservoir in these thrust-belt traps is the Jurassic Twin Creek Limestone (figure 2).

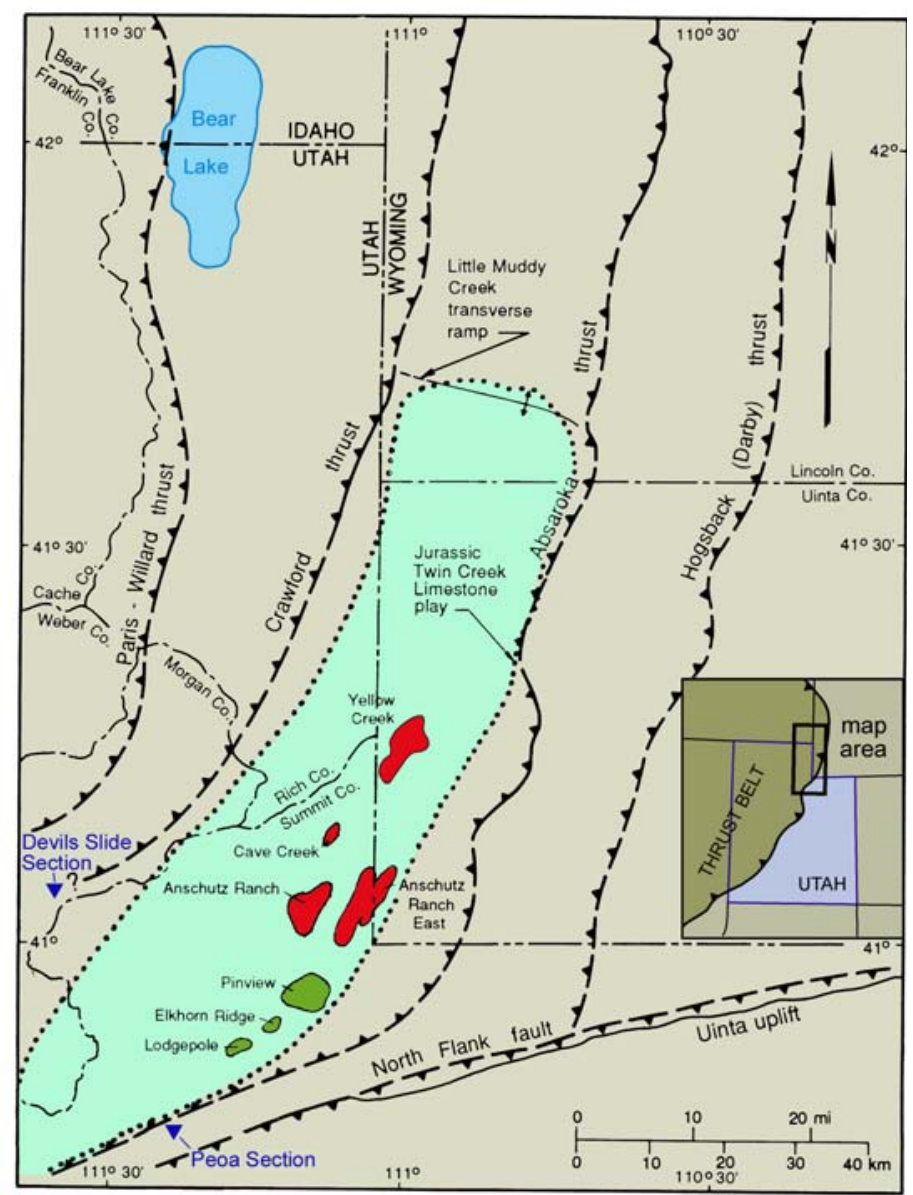

Figure 2. Location of reservoirs that produce oil (green) and gas and condensate (red) from the Jurassic Twin Creek Limestone, Utah and Wyoming; major thrust faults are dashed where approximate (teeth indicate hanging wall). The Twin Creek Limestone play area is dotted (modified from Sprinkel and Chidsey, 1993). 


\section{Twin Creek Limestone Reservoir}

The Twin Creek Limestone and equivalent rocks were deposited in a shallow-water embayment south of the main body of a Middle Jurassic sea that extended from Canada to southern Utah (Imlay, 1980; Hintze, 1993). Eustatic fluctuations caused numerous transgressions and regressions resulting in deposition of shallow-water carbonate, fine-grained clastic, and evaporite beds (Imlay, 1967, 1980; Kocurek and Dott, 1983). Seven formal members are recognized in both nearby outcrops and the subsurface within the Twin Creek Limestone play area (Imlay, 1967) (figure 3). Thickness of the Twin Creek ranges from approximately 1400 feet to nearly 1900 feet (470-630 m) (Imlay, 1967; Sprinkel and Chidsey, 1993 ) in the thrust belt, where it is overlain by the Preuss Formation and underlain by the Nugget Sandstone, both Jurassic in age.

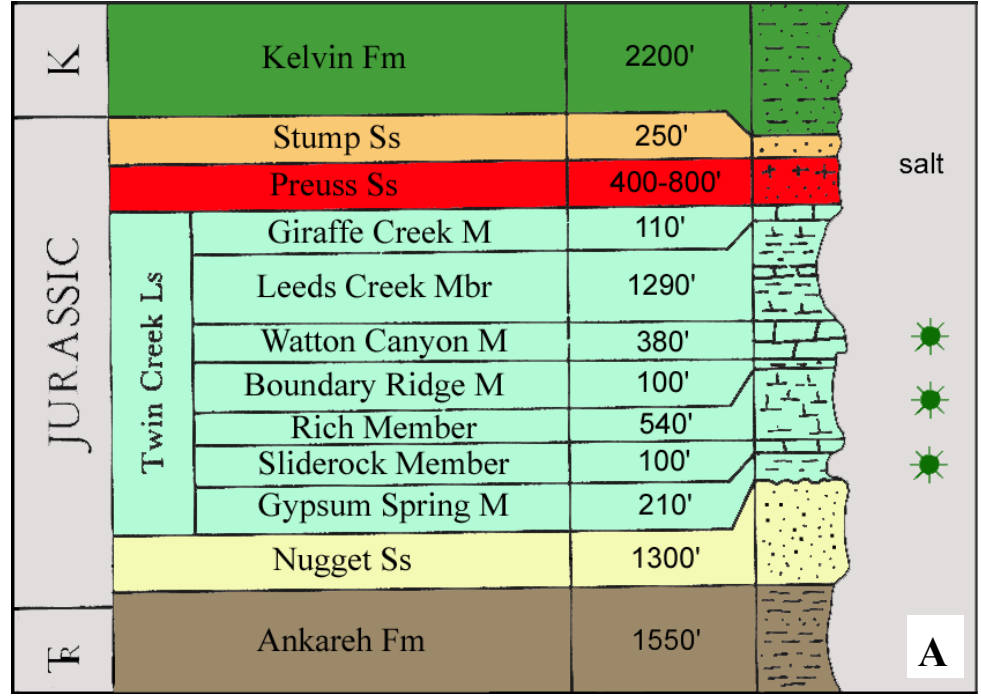

Figure 3. A - Stratigraphic column of a portion of the Mesozoic section, including members of the Jurassic Twin Creek Limestone, exposed in Weber Canyon near Devils Slide, Morgan and Summit Counties, Utah (modified from Hintze, 1993). B Typical gamma ray-resistivity log of the members of the Twin Creek Limestone, Anschutz Ranch field discovery well, Summit County, Utah.

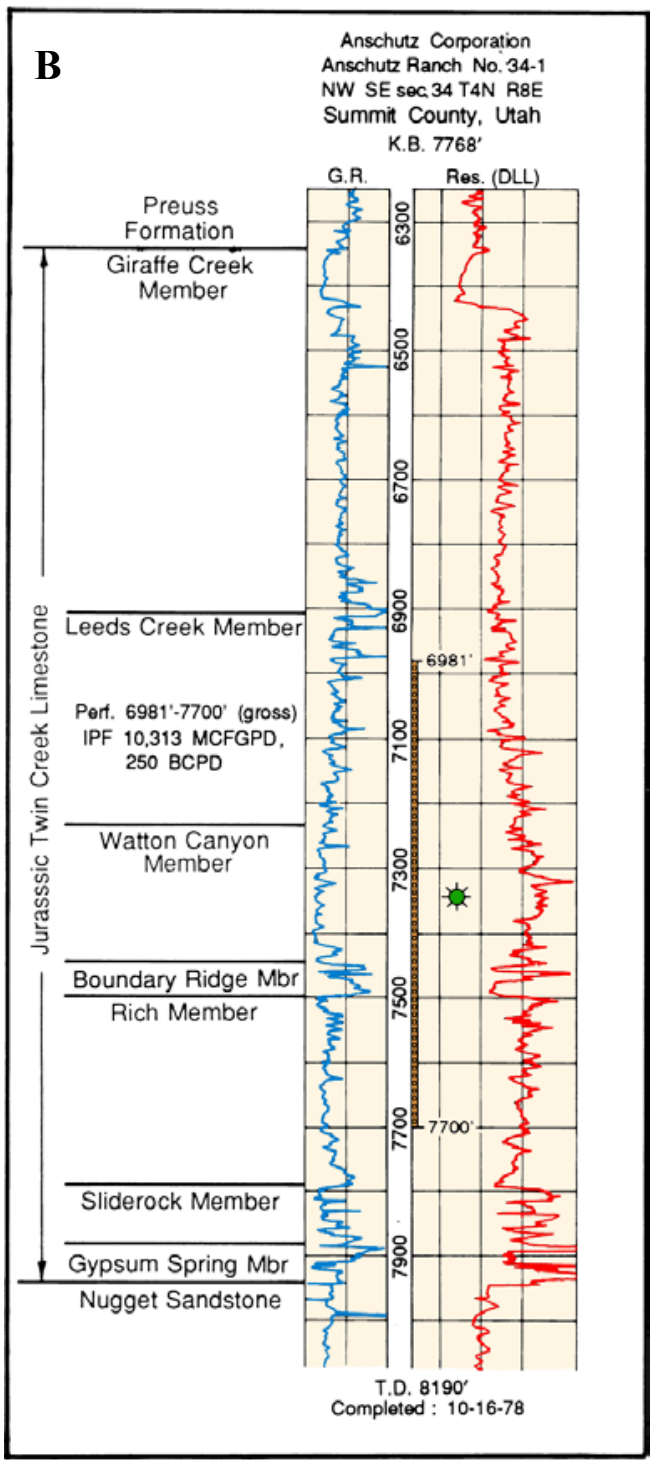


The Twin Creek Limestone is composed of a variety of lithologies including micritic to argillaceous limestone, sabkha evaporites, and redbed siltstone and claystone. Tightly cemented oolitic grainstone, dolomitized zones, and thin shaly intervals are also present (Bruce, 1988; Parra and Collier, 2000). Post-burial diagenesis includes cementation, compaction, and fracturing. Oil and gas production comes from zones in the denser, naturally fractured carbonate beds in the middle to lower part of the formation. Fracturing is related to faultpropagation folding during the Sevier orogeny (Royce and others, 1975; Conner and Covlin, 1977; Dixon, 1982; Lamerson, 1982; Bruce, 1988). In Lodgepole field (figure 2) and elsewhere, the fracturing intensity is controlled by lithology (Parra and Collier, 2000). Dolomitized mudstones deposited in backbank, low-energy brackish water environments have significant fracturing; for example the base of the Watton Canyon Member. Fracturing decreases to rare as silt content increases and dolomitization decreases; for example the Giraffe Creek and upper Leeds Creek Members (Parra and Collier, 2000). The seals for the producing horizons are overlying argillaceous and clastic beds, and non-fractured units within the Twin Creek Limestone.

Most oil and gas production is from perforated intervals in the Watton Canyon, upper Rich, and Sliderock Members (figure 3). These members have little to no primary porosity in the producing horizons (Bruce, 1988), ranging from 2 to 4 percent when present, but exhibit secondary porosity in the form of fracturing. Permeabilities in these members range from 4 to greater than 30 millidarcies (md). The permeability was also formed by natural fractures, and controls hydrocarbon production and injection fluids (Parra and Collier, 2000). The reservoir drive mechanisms are pressure depletion and solution gas.

Intensely fractured zones in the Watton Canyon and Rich Members have been the targets of horizontal wells in Lodgepole, Elkhorn Ridge, and Pineview fields, Summit County, Utah (figure 2).

\section{Twin Creek Limestone Outcrop Analogs, Devils Slide and Peoa, Utah}

The best outcrop analogs of the Twin Creek Limestone reservoir are found about 20 miles $(32 \mathrm{~km}$ ) west of Anschutz Ranch field at Devils Slide on the Crawford thrust plate (figures 2 and 4), and 9 miles $(15 \mathrm{~km})$ southwest of Lodgepole field near the town of Peoa, Utah, on the Absaroka thrust plate (?) (figures 2 and 5). Both sites are located along highways; however, the Devils Slide outcrop is within a large cement quarry operated by Holcim (U.S.) Inc. and permission must be obtained to gain access.

Although the sections are faulted and display some bed repetition, portions, or the entire thickness, of all seven Twin Creek members are exposed at the Devils Slide and Peoa sites. Sections at both sites were measured and described (appendices A and B). The Twin Creek at Devils Slide strikes generally parallel to the leading edge of the Crawford thrust (northnortheast) with beds dipping greater than $65^{\circ}$ east to overturned to the west; several small back thrusts are present (figure 4). The Twin Creek at Peoa strikes generally parallel to the leading edge of the Absaroka thrust (east-northeast) and the North Flank fault of the Uinta uplift, with beds dipping more than $70^{\circ}$ north-northwest (figure 5).

These sections display the same reservoir heterogeneity characteristics that affect production or provide horizontal drilling targets in the Twin Creek Limestone productive fields. This heterogeneity, created by fracturing (or the lack thereof), and lithologic variation provide both the reservoir storage capacity and/or seals (barriers) within the traps. Fractures in the 

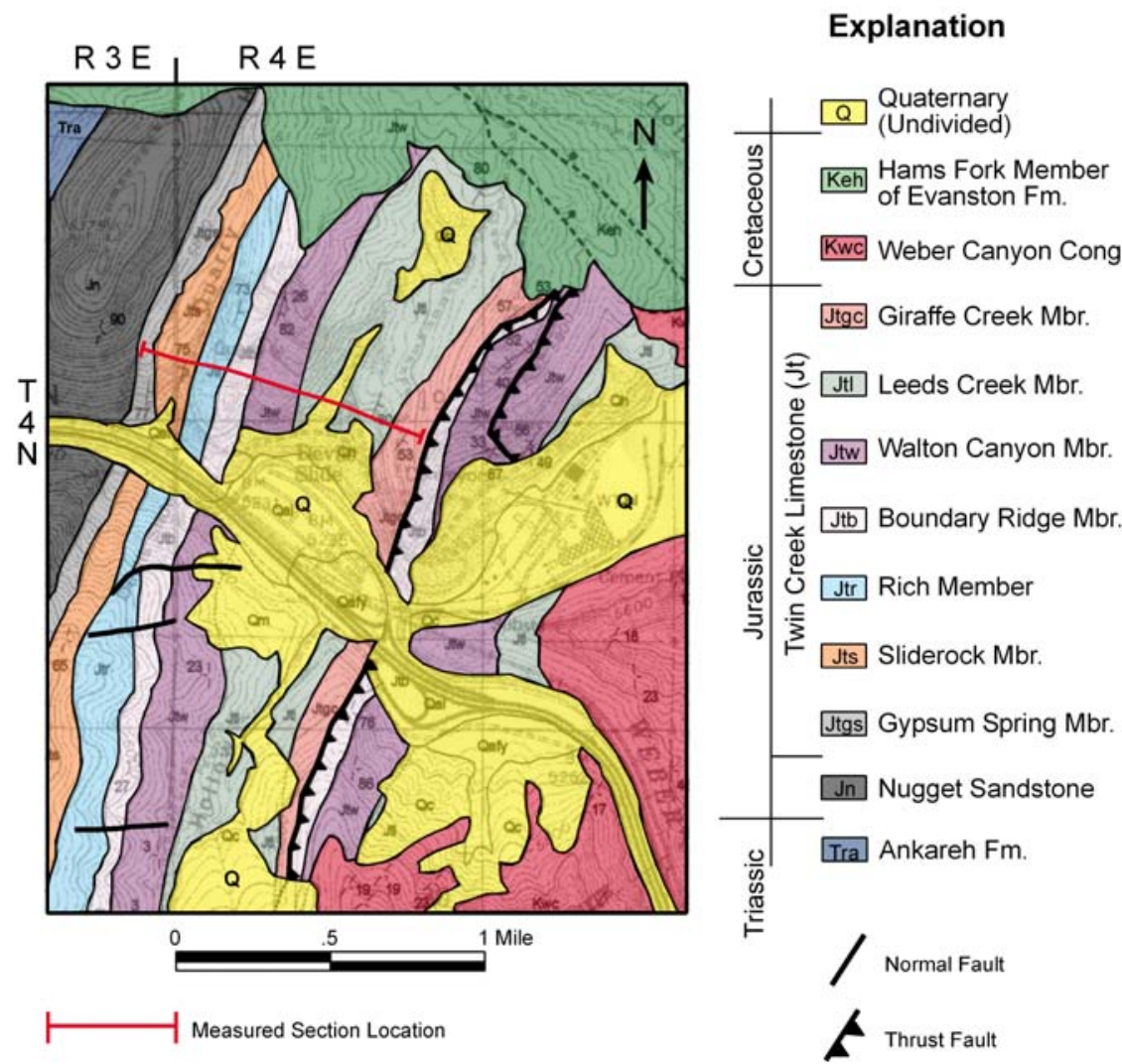

Figure 4. Geologic map of the Devils Slide area, Morgan and Summit Counties, Utah, showing the location of the stratigraphic measured section through the Twin Creek Limestone (appendix A) (modified from Coogan, 1999). See figure 2 for location of Devils Slide area.

Figure 5. Geologic map of the Peoa area, Summit County, Utah, showing the location of the stratigraphic measured section through the Twin Creek Limestone $\left(\begin{array}{ll}\text { appendix } & B\end{array}\right)$ (modified from Bryant, 1990). See figure 2 for location of Peoa area.

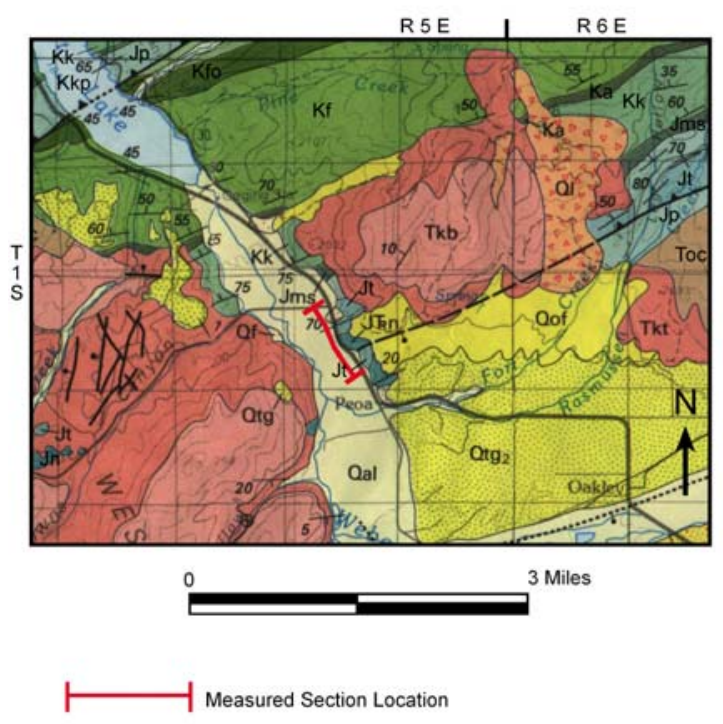

\section{Explanation}

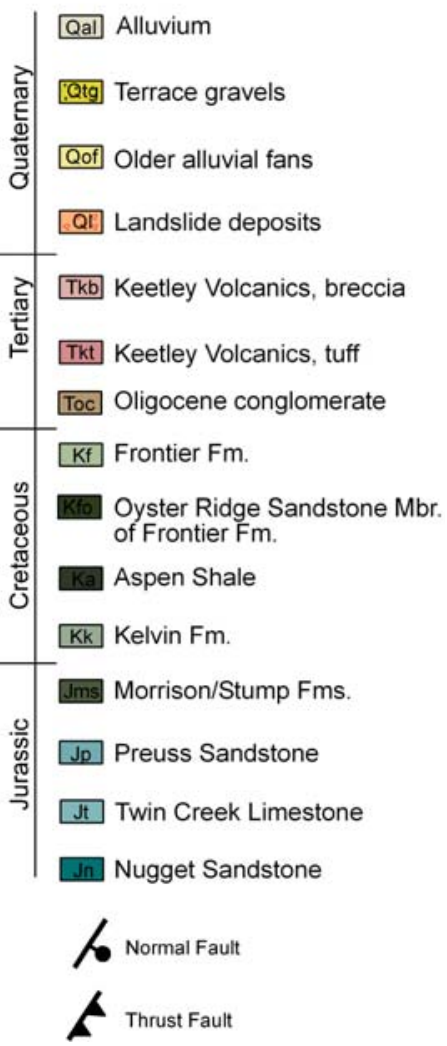


Twin Creek, as is the case with other sedimentary rocks, generally have a consistent geometry with respect to the three principal stresses $\left(\sigma_{1}=\right.$ greatest, $\sigma_{2}=$ intermediate, $\sigma_{3}=$ least principal compressive effective stress) at the time of the fracture (Stearns, 1984). Fractures near faults depict the stress field responsible for the fault. Fractures in folds are genetically related to the folding process itself, not a consequence of the regional stress field that produced the folding. Parallel fracture sets are commonly present, and their geometry results from compression and extension (when $\sigma_{2}$ is either parallel or normal to bedding) associated with the fold development as well as the type of sedimentary rock involved (Stearns, 1984). Four different orientations of the three principal stresses are recognized in folds (figure 6): (1) $\sigma_{1}$ and $\sigma_{3}$ in the bedding plane, $\sigma_{1}$ parallel to the dip direction, $(2) \sigma_{1}$ and $\sigma_{3}$ in the bedding plane, $\sigma_{1}$ parallel to the strike direction, (3) $\sigma_{2}$ parallel to bedding strike, $\sigma_{1}$ normal to bedding, and (4) $\sigma_{2}$ parallel to bedding strike, $\sigma_{3}$ normal to bedding. These four orientations produce 12 possible fracture planes - two shear and one extension for each orientation (Stearns, 1984).
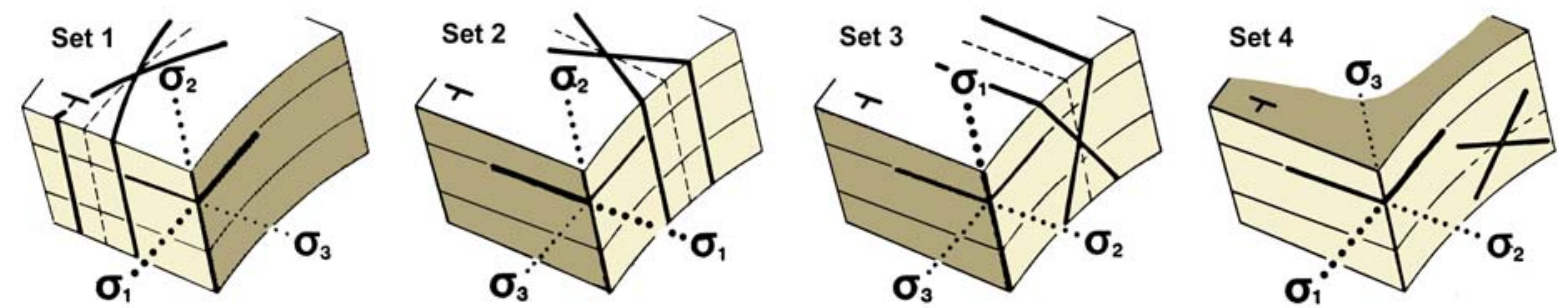

Figure 6. Fracture planes generated by four orientations of the three principal stresses during folding of sedimentary rocks (after Stearns, 1984).

Both faulting and folding account for outcrop orientations at the Devils Slide and Peoa sites. Thus, fractures as described above have likely been generated by these structural events. The general fracture pattern observed in the rocks at these locations can be applied to planning directions of horizontal wells proposed in the Twin Creek Limestone play.

The following sections are general outcrop descriptions of each member of the Twin Creek Limestone, in ascending order, compiled from the Devils Slide and Peoa field observations and the measured stratigraphic sections (appendices A and B). Detailed descriptions, regional correlation, fossils, and depositional environments of these members are included in Imlay (1967).

Gypsum Spring Member: The Gypsum Spring Member consists of shale (covered) and a basal pebble-rich to coarse-grained sandstone. Bedding is thick to medium, and tabular. The sandstone is composed of rounded to subrounded frosted grains derived from the underlying Nugget Sandstone.

Sliderock Member: The Sliderock Member is composed of dark gray, micritic limestone. It is medium to thick bedded, often forming a resistant ledge with some thin laminations and silt partings. Fractures are abundant and commonly closely spaced. Some less resistant (highly fractured) units weather into slopes littered with plates, chips, and pencils. 
Rich Member: Devils Slide is composed of resistant and non-resistant units of the Rich Member (figure 7). The Rich consists of dense, finely crystalline to micritic limestone with some sandy to calcarenite units forming the lower and upper resistant ledges of Devils Slide, respectively (figure 7). Redbrown, calcareous siltstone forms the nonresistant center of Devils Slide. Laminated siltstone partings and sandy limestone are also found in several units of the Rich. Bedding is thick to thin with occasional planar cross-beds and current ripples (figure $8 \mathrm{~A})$.

Rhombic fracture patterns are developed on bedding planes (figures $8 \mathrm{~B}$ and $8 C$ ), likely the result of $\sigma_{1}$ and $\sigma_{3}$ in the bedding plane, with $\sigma_{1}$ parallel to the dip direction (set 1 on figure 6). Weathering along closely spaced rectilinear fractures within dense homogeneous limestone beds yields abundant pencils and plates (figures $8 \mathrm{D}$ and $8 \mathrm{E}$ ). Two sets of rhombic fractures, low angle and high angle in relationship to bedding, and another set parallel to bedding are apparent in the outcrop shown on figure 8D. As shown on figure 6 , these fractures correspond to both set 3 , where $\sigma_{2}$ is parallel to bedding strike and $\sigma_{1}$ is normal to

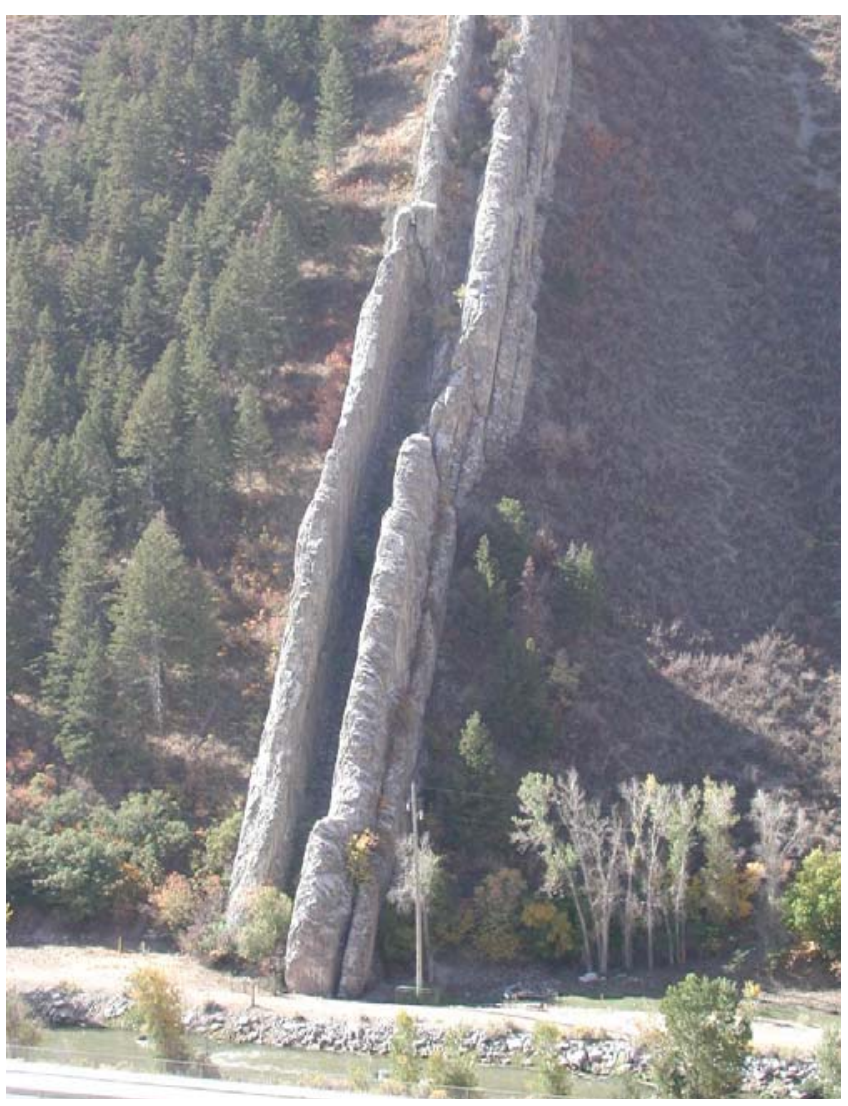

Figure 7. Devils Slide, a famous landmark along Interstate 84 in Weber Canyon, composed of resistant and non-resistant units of the Rich Member of the Twin Creek Limestone. bedding, and set 4 , where $\sigma_{2}$ is parallel to bedding strike and $\sigma_{3}$ is normal to bedding.

There is little to no primary porosity within the crystalline to micritic limestone units of the Rich. However, the contact with the basal siltstone unit (where fractures are sealed) of the overlying Boundary Ridge Member sets up the Rich for hydrocarbon trapping and production (figure 8F).

Boundary Ridge Member: The Boundary Ridge Member is composed of dark, red-brown siltstone to claystone, gray-green, micritic limestone, and very fine to fine-grained, well-sorted, gray sandstone and calcarenite. Bedding is thin to thick, with some contorted bedding (within lensoidal-shaped bodies), cross-bedding, parallel lamina, and occasional ripples. Some units contain peloids and possible fossil hash.

Watton Canyon Member: The Watton Canyon Member is composed of dark to medium gray, dense, resistant, finely crystalline to micritic limestone. Bedding is thin to thick, with largescale current ripples and silty lamina that exhibit cross-bedding in some units. Limestones occasionally contain stylolites, oolites, peloids, and fossils (primarily pelecypods). 

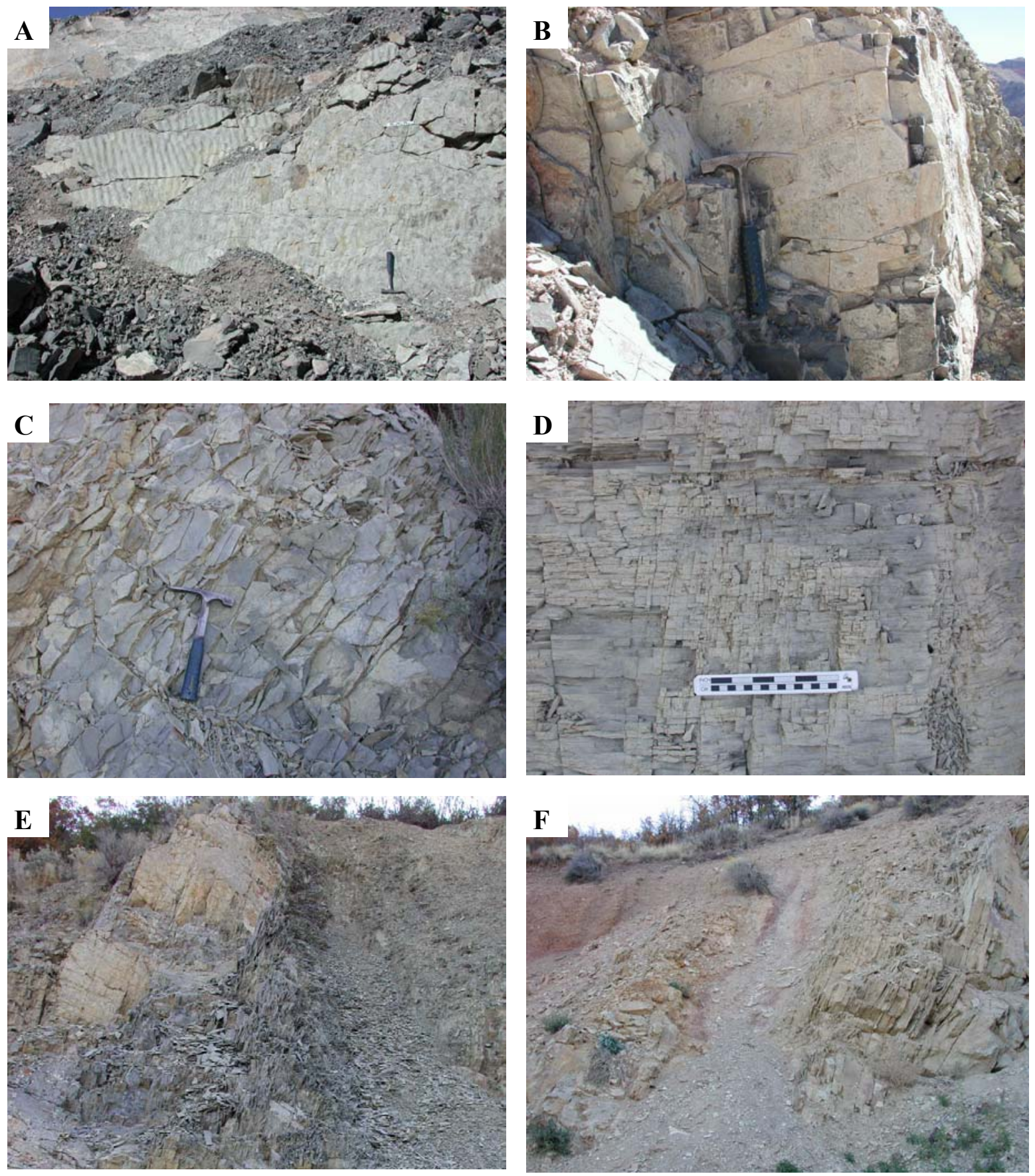

Figure 8. Characteristics of the Rich Member of the Twin Creek Limestone. A - Welldeveloped current ripples on bedding surface with silt-filled fractures, Devils Slide section. $B$ and $C$ - Rhombic fracture patterns on bedding planes, Devils Slide and Peoa sections, respectively. $D$-Closely spaced rectilinear fracturing, Peoa section, $E$-Pencil weathering, Peoa section. F-Contact between fractured Rich Member limestone and basal siltstone with sealed fractures of the overlying Boundary Ridge Member, Peoa section. 
Rectilinear fracturing is pervasive and includes both open and calcite-filled fractures (figure 9A through 9D); calcite-filled vugs are also present in some beds. Rhombic fracture patterns on bedding planes (figures 9A through 9D) formed from stresses with $\sigma_{1}$ and $\sigma_{3}$ in the bedding plane and with $\sigma_{1}$ parallel to the dip direction (set 1 on figure 6), and/or from $\sigma_{1}$ and $\sigma_{3}$ in the bedding plane, and $\sigma_{1}$ parallel to the strike direction (set 2 on figure 6). Fractures also occur parallel to strike on the bedding planes as shown in figures 9A and 9D, and correspond to set 3 on figure 6 , where $\sigma_{2}$ is parallel to bedding strike and $\sigma_{1}$ is normal to bedding. The differing fracture patterns formed as the stress fields changed with folding and faulting of the stratigraphic sections over time.

Like the Rich Member, the uppermost fractured limestone unit of the Watton Canyon Member is sealed, in this case by the argillaceous basal unit of the overlying Leeds Creek Member (figure 9E). Reservoir heterogeneity within the Watton Canyon itself is observed in outcrop, where thin-bedded siltstones create additional barriers or baffles to fluid flow (figure 9F).

Leeds Creek Member: The Leeds Creek Member is composed of interbedded gray, laminated, fissle to dense, microcrystalline limestone, red-brown siltstone to gray-green calcareous mudstone, and very fine grained, well-sorted sandstone and calcarenite. Bedding is thin to thick, weathering into small chips, thick pencils, and plates. Some limestone units contain peloids or coated grains. Argillaceous or clay-rich units may contain sandy interference ripples and cross-beds. Fractures and vugs tend to be calcite filled; calcite veinlets may also be present.

Giraffe Creek Member: The Giraffe Creek Member is composed of interbedded moderately resistant, gray, medium crystalline limestone, calcareous siltstone, and fine- to medium-grained calcarenite. Some units contain oolites, and coated and lithic grains. Cross-bedding and current and interference ripples are also common; a few silty beds are lensoid. At the Devils Slide section, a rectilinear fracture pattern at the top of the Giraffe Creek is marked by a beddingparallel back thrust (figure 4).

\section{Paradox Basin Province}

The Paradox Basin is located mainly in southeastern Utah and southwestern Colorado, with a small portion in northeastern Arizona and northwestern New Mexico (figure 1A). The Paradox Basin is an elongate, northwest-southeast-trending evaporitic basin that predominately developed during the Pennsylvanian. The basin can generally be divided into three areas: the Paradox fold and fault belt in the north, the Blanding sub-basin in the south-southwest, and the Aneth platform in southeastern most Utah (figure 1A). The Mississippian Leadville Limestone is one of two major oil and gas reservoirs in the Paradox Basin, the other being the Pennsylvanian Paradox Formation. Most Leadville production is found in the Paradox fold and fault belt (figure 10).

The most obvious structural features in the basin are the spectacular anticlines that extend for miles in the northwesterly-trending fold and fault belt. The events that caused these and many other structural features to form began in the Proterozoic when movement initiated on high-angle basement faults and fractures 1700 to $1600 \mathrm{Ma}$ (Stevenson and Baars, 1987). During Cambrian through Mississippian time, this region, as well as most of eastern Utah, was 

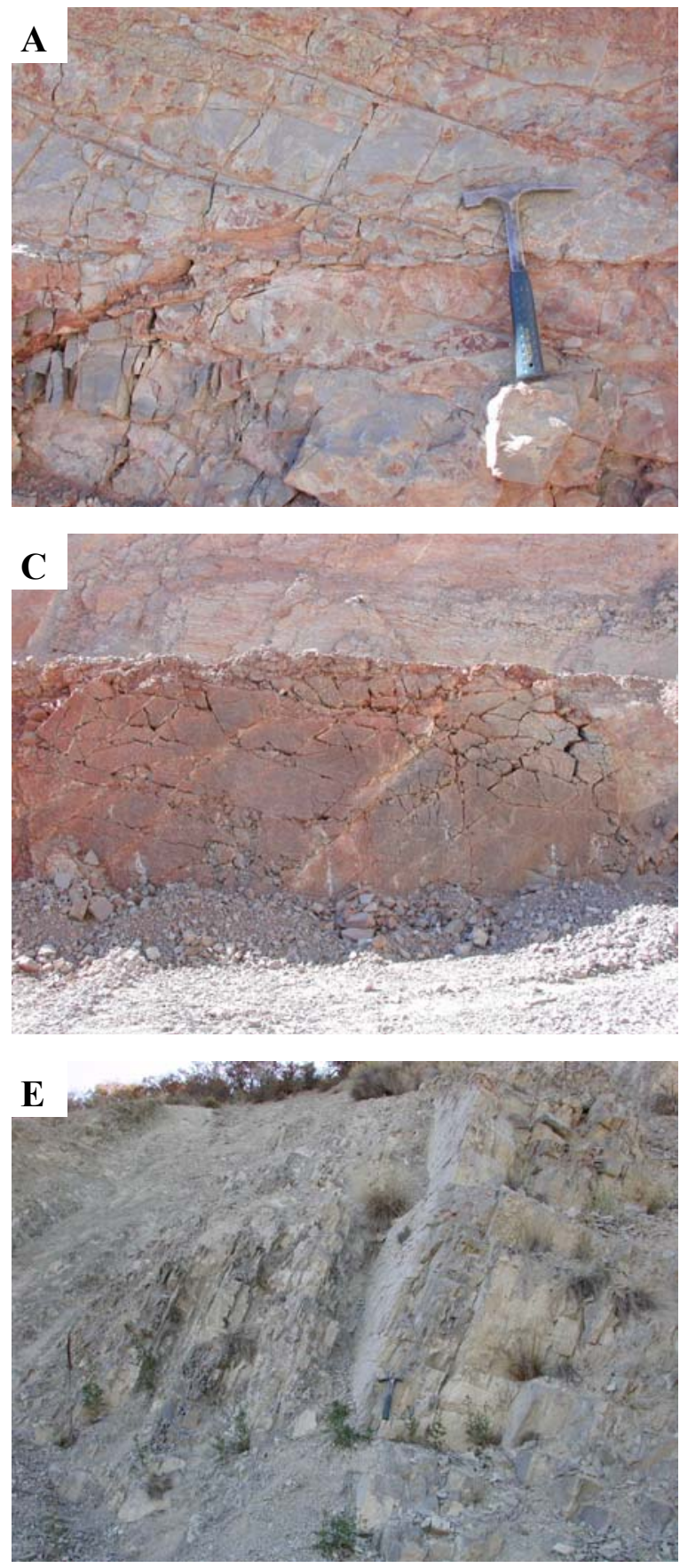
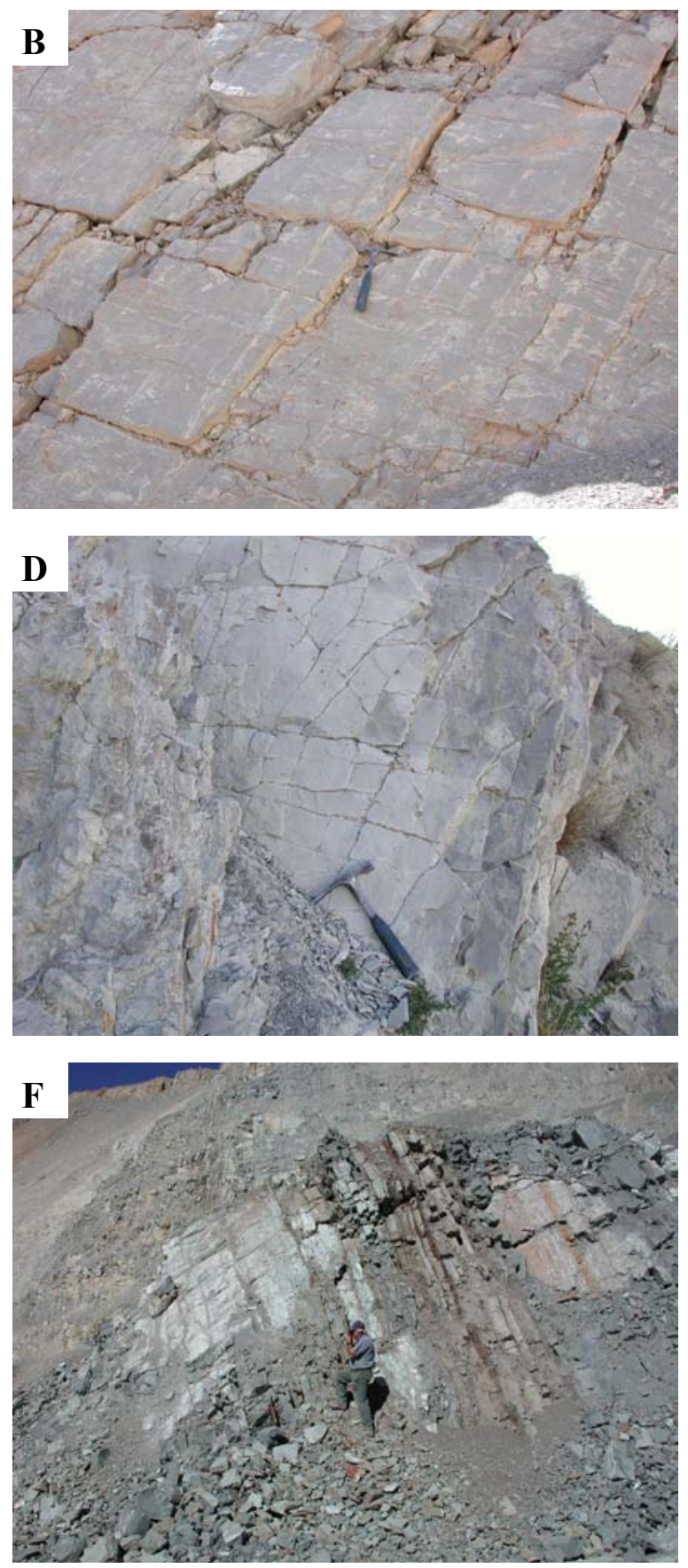

Figure 9. Characteristics of the Watton Canyon Member of the Twin Creek Limestone. A Closely spaced rectilinear fracturing in dense, micritic limestone, Devils Slide section. B Large-scale, well-displayed rectilinear fracturing in steeply dipping limestone, Devils Slide section. C - Large-scale, open fractures on bedding plane surface, Devils Slide section. D Well-displayed rectilinear fracturing on top of the Watton Canyon, Peoa section. E Contact between fractured Watton Canyon Member limestone and basal argillaceous unit of the overlying Leeds Creek Member, Peoa section. F-Heterogeneity within the Watton Canyon Member caused by thin-bedded siltsone, Devils Slide section. 
the site of typical, thin, marine deposition on a craton while thick deposits accumulated in the miogeocline to the west (Hintze, 1993). However, major changes occurred beginning in the Pennsylvanian. A series of basins and fault-bounded uplifts developed from Utah to Oklahoma as a result of the collision of South America, Africa, and southeastern North America (Kluth and Coney, 1981; Kluth, 1986), or from a smaller scale collision of a microcontinent with south-central North America (Harry and Mickus, 1998). One result of this tectonic event was the uplift of the Ancestral Rockies in the western United States. The Uncompahgre Highlands in eastern Utah and western Colorado initially formed as the westernmost range of the Ancestral Rockies during this ancient mountainbuilding period. The southwestern flank of the Uncompahgre Highlands (uplift) is bounded by a large basement-involved, high-angle reverse fault identified from seismic surveys and exploration drilling. As the highlands rose, an accompanying depression, or foreland basin, formed to the southwest - the Paradox Basin. Rapid subsidence, particularly during the

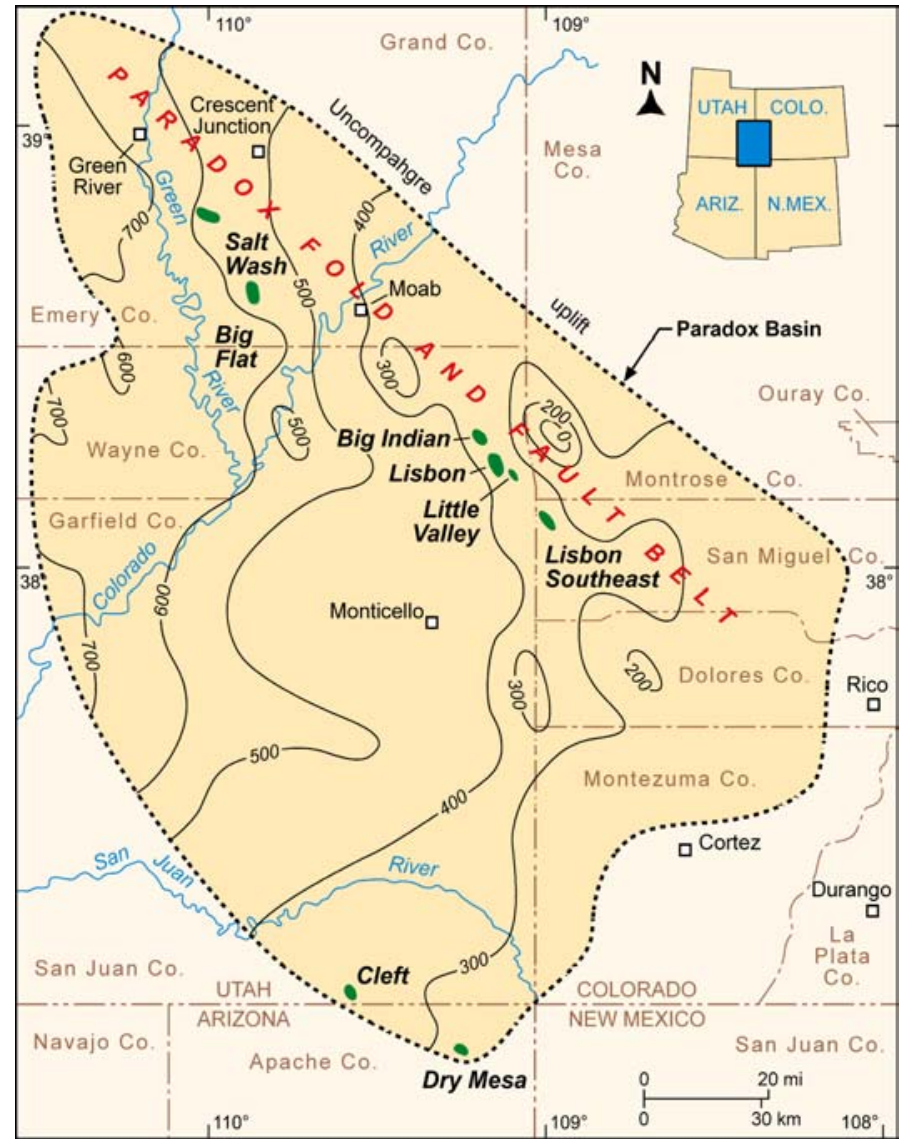

Figure 10. Location of reservoirs that produce oil (green) and gas and condensate (red) from the Mississippian Leadville Limestone, Utah and Colorado. Thickness of the Leadville is shown; contour interval is 100 feet (modified from Parker and Roberts, 1963).

Pennsylvanian and continuing into the Permian, accommodated large volumes of evaporitic and marine sediments that intertongue with non-marine arkosic material shed from the highland area to the northeast (Hintze, 1993).

The Paradox Basin is surrounded by other uplifts and basins, which formed during the Late Cretaceous-early Tertiary Laramide orogeny (figure 1). The Paradox fold and fault belt was created during the Tertiary and Quaternary by a combination of: (1) reactivation of basement normal faults; (2) salt flowage, dissolution and collapse; and (3) regional uplift (Doelling, 2000).

Oil and gas are produced from the Leadville Limestone from basement-involved, northwest-trending structural traps with closure on both anticlines and faults. The Leadville Limestone has produced over 53 million barrels $\left(8.4\right.$ million $\left.\mathrm{m}^{3}\right)$ of oil and 826 billion cubic feet (23.4 billion $\left.\mathrm{m}^{3}\right)$ of gas from six fields in the northern Paradox Basin of Utah and Colorado. This $7500-\mathrm{mi}^{2}\left(19,400 \mathrm{~km}^{2}\right)$ area is relatively unexplored; only about 100 wells penetrate the Leadville (less than one well per township), thus the potential for new discoveries remains great. 


\section{Leadville Limestone Reservoir}

The Mississippian (late Kinderhookian through Osagean to early Meramecian time) Leadville Limestone is a shallow, open-marine, carbonate-shelf deposit. The western part of the Paradox fold and fault belt includes a regional, reflux-dolomitized interior bank facies containing Waulsortian mounds (Welsh and Bissell, 1979). During Late Mississippian time, the entire carbonate platform in southeastern Utah and southwestern Colorado was subjected to subaerial erosion resulting in formation of a lateritic regolith (Welsh and Bissell, 1979). This regolith and associated carbonate dissolution is an important factor in Leadville reservoir potential. The Leadville Limestone thins from more than 700 feet $(230 \mathrm{~m})$ in the northwest corner of the Paradox Basin to less than 200 feet $(70 \mathrm{~m})$ in the southeast corner (Morgan, 1993) (figure 11). It is overlain by the Pennsylvanian Molas Formation and underlain by the Devonian Ouray Limestone.

Periodic movement along northwest-trending faults affected deposition of the Leadville Limestone. Crinoid banks or mounds (primary reservoir facies) accumulated in shallow-water environments on upthrown fault blocks or other paleotopographic highs. In areas of greatest paleorelief, the Leadville is completely missing as a result of non-deposition or subsequent erosion (Baars, 1966).

The Leadville Limestone is divided into two members separated by an intraformational discomformity (figure 11B). The dolomitic lower member is composed of mudstone, wackestone, packstone, and grainstone deposited in shallow-marine, subtidal, supratidal, and intertidal environments (Fouret, 1996). Fossils include crinoids, fenestrate bryozoans, and brachiopods. Locally, mud-supported boundstone creates buildups or mud mounds similar to Waulsortian facies (Wilson, 1975; Ahr, 1989; Fouret, 1996). The upper member is composed of mudstone, packstone, grainstone (limestone and dolomite), and terrigenous clastics also deposited in subtidal, supratidal, and intertidal environments (Fouret, 1996). Fossils include crinoids and rugose coral. Reservoir rocks are crinoid-bearing packstone (Baars, 1966).

Intercrystalline porosity developed between dolomite rhombs, while vugs and moldic porosity formed by the dissolution of fossils. Porosity averages 6 to 8 percent. At Lisbon field, San Juan County, Utah (figure 10), the permeability ranges from less than $1 \mathrm{md}$ to $1100 \mathrm{md}$, averaging 22 md (Smouse, 1993). Solution breccia and karstified surfaces are common, including possible local development of cavernous zones (Fouret, 1996). Reservoir quality is greatly improved by natural fracture systems associated with the Paradox fold and fault belt. The reservoir drive mechanisms are gas expansion and, to a lesser degree, gravity drainage. Many Leadville reservoirs have a gas cap with an oil ring containing associated gas.

In summary, three factors create reservoir heterogeneity within productive zones: (1) variations in carbonate fabrics and facies, (2) diagenesis (including karstification), and (3) fracturing. The extent of these factors and how they are combined affect the degree to which they create barriers to fluid flow.

\section{Leadville Limestone Outcrop Analogs, South Flank of the Uinta Mountains, Utah}

Although not exposed in southeastern Utah, Mississippian rocks equivalent to the Leadville Limestone outcrop in the northern and western parts of the state (figure 12). These formations include the Madison, Gardison, and Deseret Limestones (figure 13), and have generally the same characteristics as the Leadville (if the Delle Phosphatic Member is present, 


\begin{tabular}{|c|c|c|c|c|c|}
\hline Z & \multirow{2}{*}{$\begin{array}{c}\text { Hermosa } \\
\text { Group }\end{array}$} & Paradox Fm & $2000-5000^{\prime}$ & $\begin{array}{l}\overline{x x} \\
\pm \pm E\end{array}$ & \multirow[t]{3}{*}{$\begin{array}{c}\text { potash \& } \\
\text { salt }\end{array}$} \\
\hline LI & & Pinkerton Trail Fm & $0-150^{\prime}$ & & \\
\hline A & \multicolumn{2}{|c|}{ Molas Formation } & $0-100^{\prime}$ & & \\
\hline$\sum$ & \multicolumn{2}{|c|}{ Leadville Limestone } & $300-600^{\prime}$ & & 米 \\
\hline & \multicolumn{2}{|c|}{ Ouray Limestone } & $0-150^{\prime}$ & & \multirow[b]{3}{*}{ 恭 } \\
\hline 红 & \multicolumn{2}{|c|}{ Elbert Formation } & $100-200^{\prime}$ & 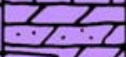 & \\
\hline Q & & McCracken Ss M & $25-100^{\prime}$ & & \\
\hline$\Psi$ & \multicolumn{2}{|c|}{ "Lynch"Dolomite } & $800-1000^{\prime}$ & & $\mathbf{A}$ \\
\hline
\end{tabular}

Figure 11. A - Stratigraphic column of a portion of the Paleozoic section determined from subsurface well data in the Arches-Moab-La Sal area, Grand and San Juan Counties, Utah (modified from Hintze, 1993). B - Typical gamma ray-sonic log of the Leadville Limestone, Lisbon field discovery well, San Juan County, Utah. See figure 10 for location of Lisbon field.

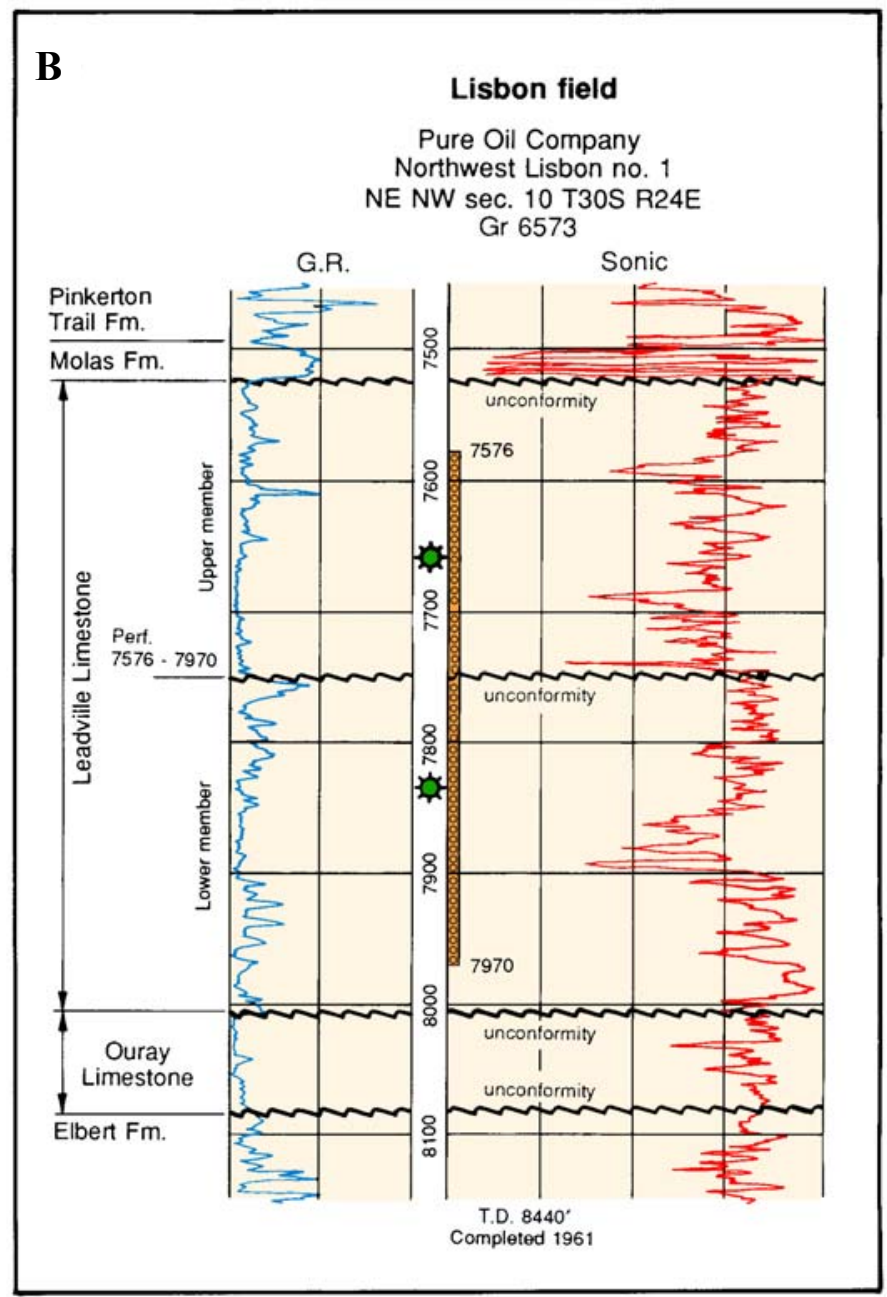

the formation is the equivalent Deseret Limestone [Hintze, 1993]). They provide productionscale analogs of the facies characteristics, geometry, distribution, and the nature of boundaries contributing to the overall heterogeneity of Leadville reservoir rocks. Excellent examples of Leadville-equivalent rocks (Madison Limestone) are found along the south flank of the Uinta Mountains where they are up to 600 feet $(200 \mathrm{~m})$ thick (figure 12). 


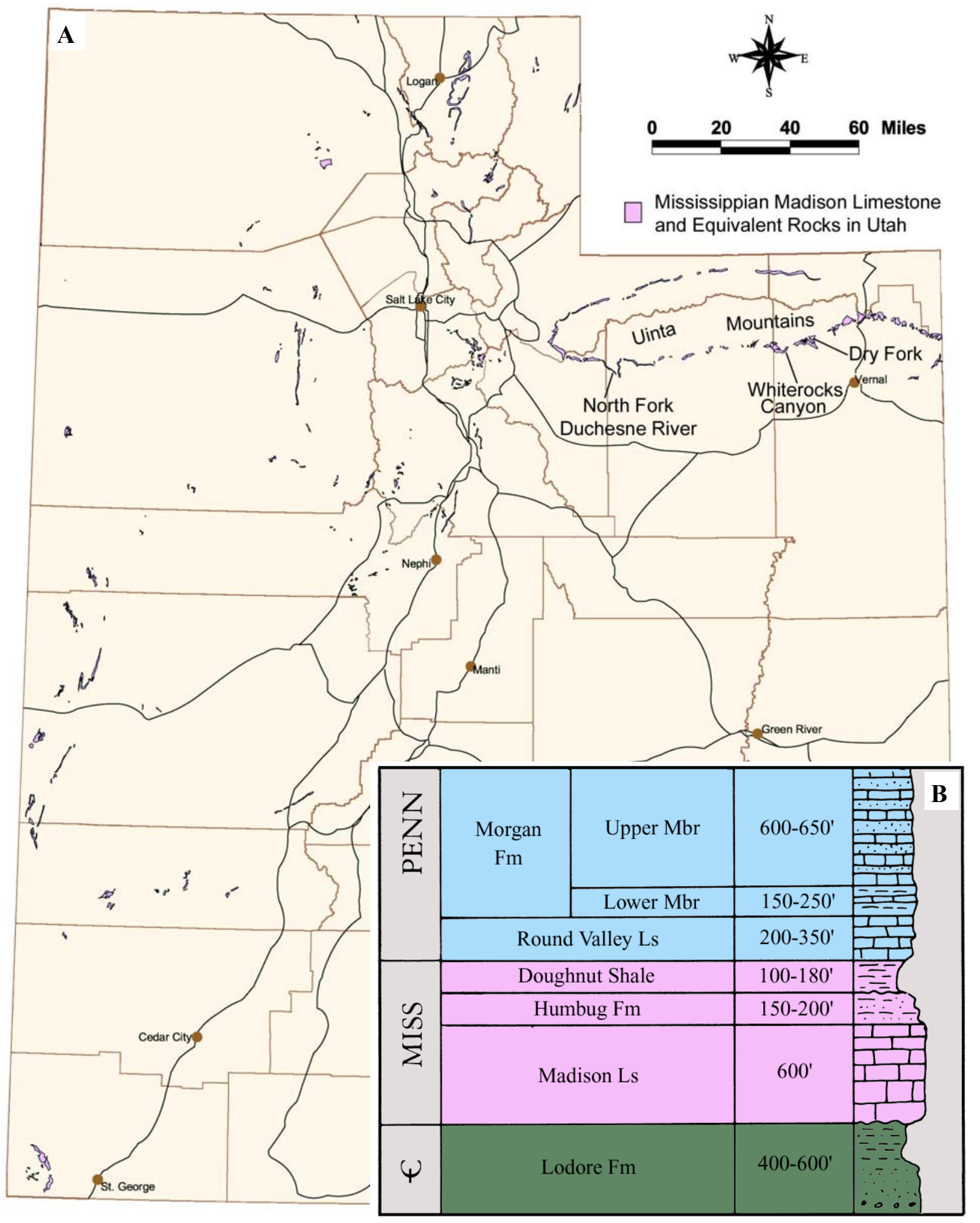

Figure 12. A - Location of Mississippian rock outcrops in Utah equivalent to the Leadville Limestone. B - Stratigraphic column of a portion of the Paleozoic section along the south flank of the Uinta Mountains (modified from Hintze, 1993). 


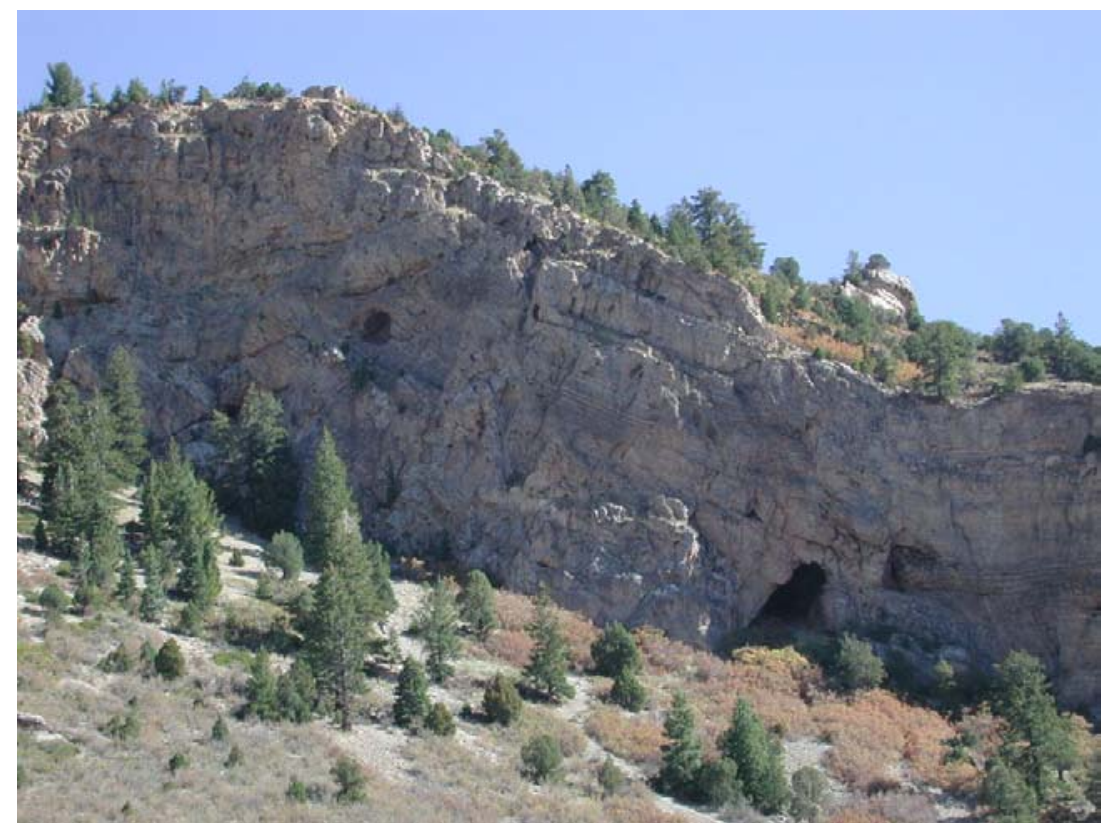

Figure 13. Mississippian Deseret Limestone forming a jagged, vertical cliff, North Fork of the Duchesne River, Duchesne County, Utah. Note the cavernous nature of the outcrop. See figure $12 \mathrm{~A}$ for location of North Fork of the Duchesne River area.

The Madison Limestone is mostly light- to dark-gray, fine- to coarse-crystalline, cherty limestone (figure 14A). Dolomitic units are gray to tan, sucrosic to crystalline, and medium bedded with occasional silty partings. The Madison is generally thick to massive and unevenly bedded, forming vertical cliffs and dip slopes. Fossils include corals, brachiopods, crinoids, pelecypods, and gastropods (Rowley and Hansen, 1979); however, fossils are relatively rare in some areas. Chert is typically light gray, forming lenses and nodules. In the Whiterocks Canyon area (figure 12), the Madison contains some thin-bedded, tan, calcareous, fine- to medium-grained sandstone (Kinney, 1955).

The Madison, Gardison, and Deseret Limestones commonly contain numerous caverns, sinkholes, and local zones of solution breccia and vugs (figures 13, 14B, and 14C). Stylolites, jointing, and fractures are also present creating rock sections with high heterogeneity (figures 14A, 14B, 14D, and 14E). Possible buildups or mud mounds comparable to Waulsortian facies are found in the Madison Limestone in Dry Fork Canyon (figures 12 and 14F).

\section{BEST PRACTICES, SOUTHERN GREEN RIVER FORMATION PLAY, UINTA BASIN - DISCUSSION AND RESULTS}

\section{Uinta Basin Province}

The Uinta Basin is a major depositional and structural basin that subsided and contained large lakes during the early Cenozoic (figure 1B). The Green River and Wasatch Formations, consisting of over 11,000 feet $(3600 \mathrm{~m})$ of Paleocene through Eocene sedimentary rocks, accumulated in and around Lakes Uinta and Flagstaff in an intertonguing relationship (figure 15). Major depositional facies are alluvial, marginal lacustrine, and open lacustrine. Hydrocarbons are typically trapped in fluvial-deltaic, distributary-channel, bar, and beach sandstone, which pinch out regionally updip or across subtle anticlinal noses. Fractures often play an important role in increasing reservoir permeability. 

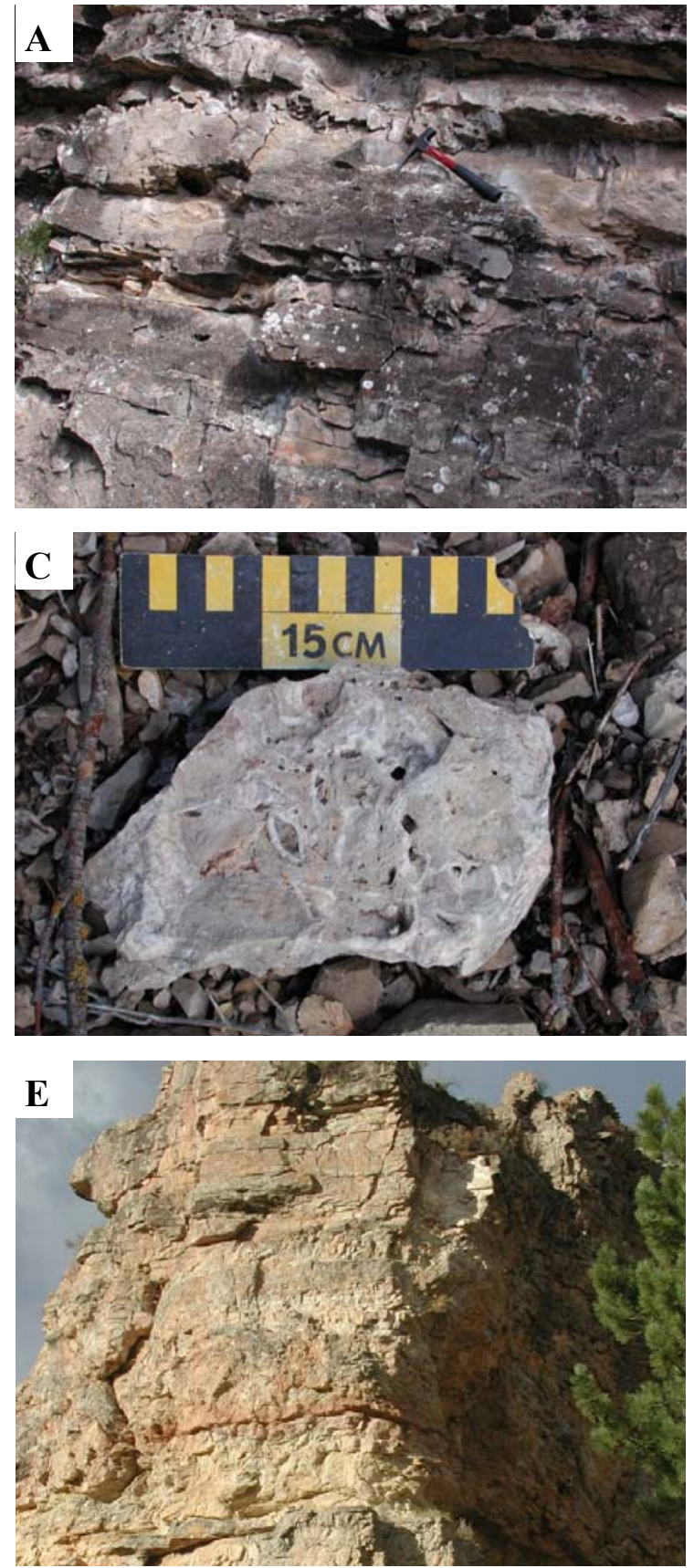
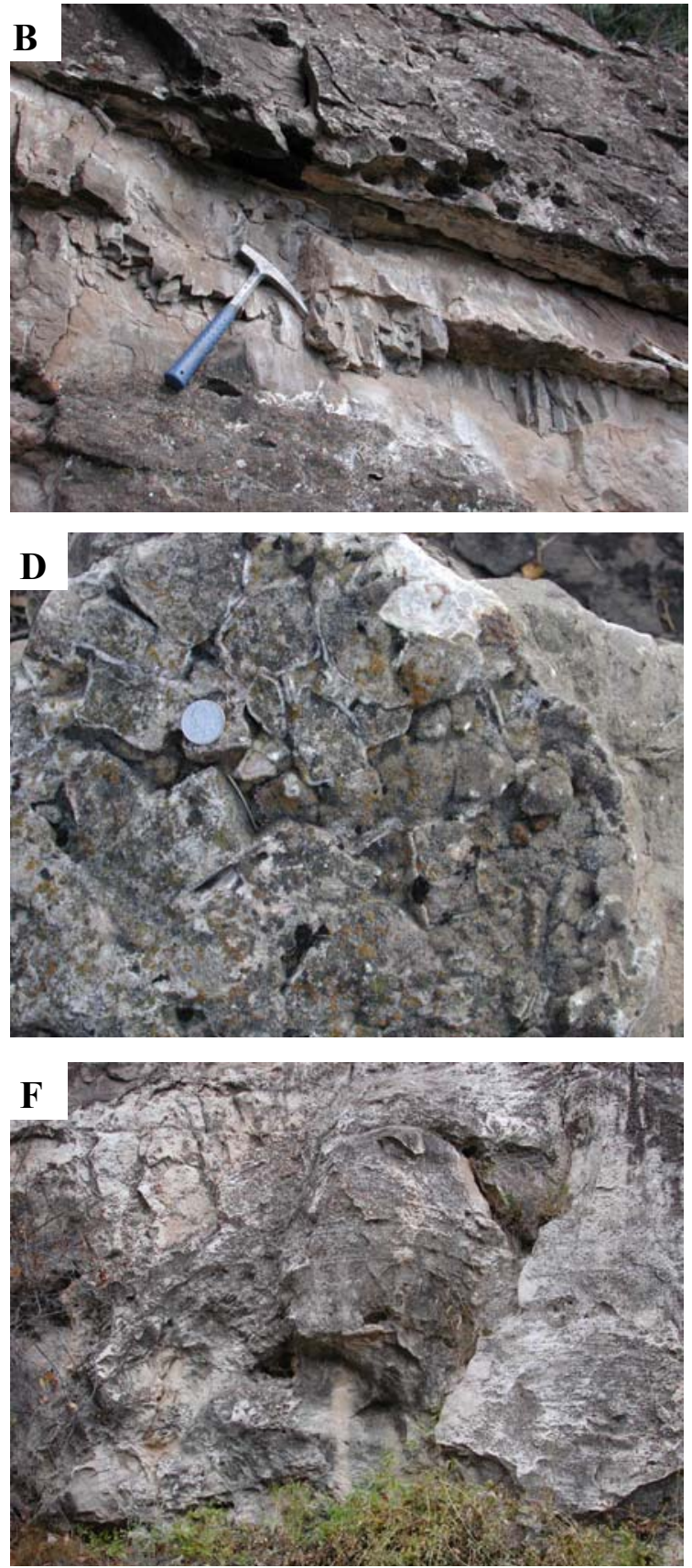

Figure 14. Characteristics of the Mississippian Madison Limestone along the south flank of the Uinta Mountains, Uintah County, Utah. A - Typical exposure of light to dark gray, medium bedded, fine to coarse crystalline, limestone and dolomite containing fractures, stylolites, and crinoid hash, Whiterocks Canyon. B - Vugs and fractures in limestone and dolomitic units, Whiterocks Canyon. C-Close-up of open and calcite-filled vugs in limestone matrix, Whiterocks Canyon. D-Close-up of small-scale, calcite-filled rectilinear fractures in limestone matrix, Whiterocks Canyon. $E-A$ combination of interbedded limestone and dolomite, containing fractures and zones of solution breccia and vugs, results in a heterogeneous stratigraphic section, Dry Fork Canyon. F-Possible small-scale carbonate buildup or mud mound (outcrop is approximately 10 feet [3 m] high), Dry Fork Canyon. See figure $12 A$ for locations of Whiterocks and Dry Fork Canyons. 


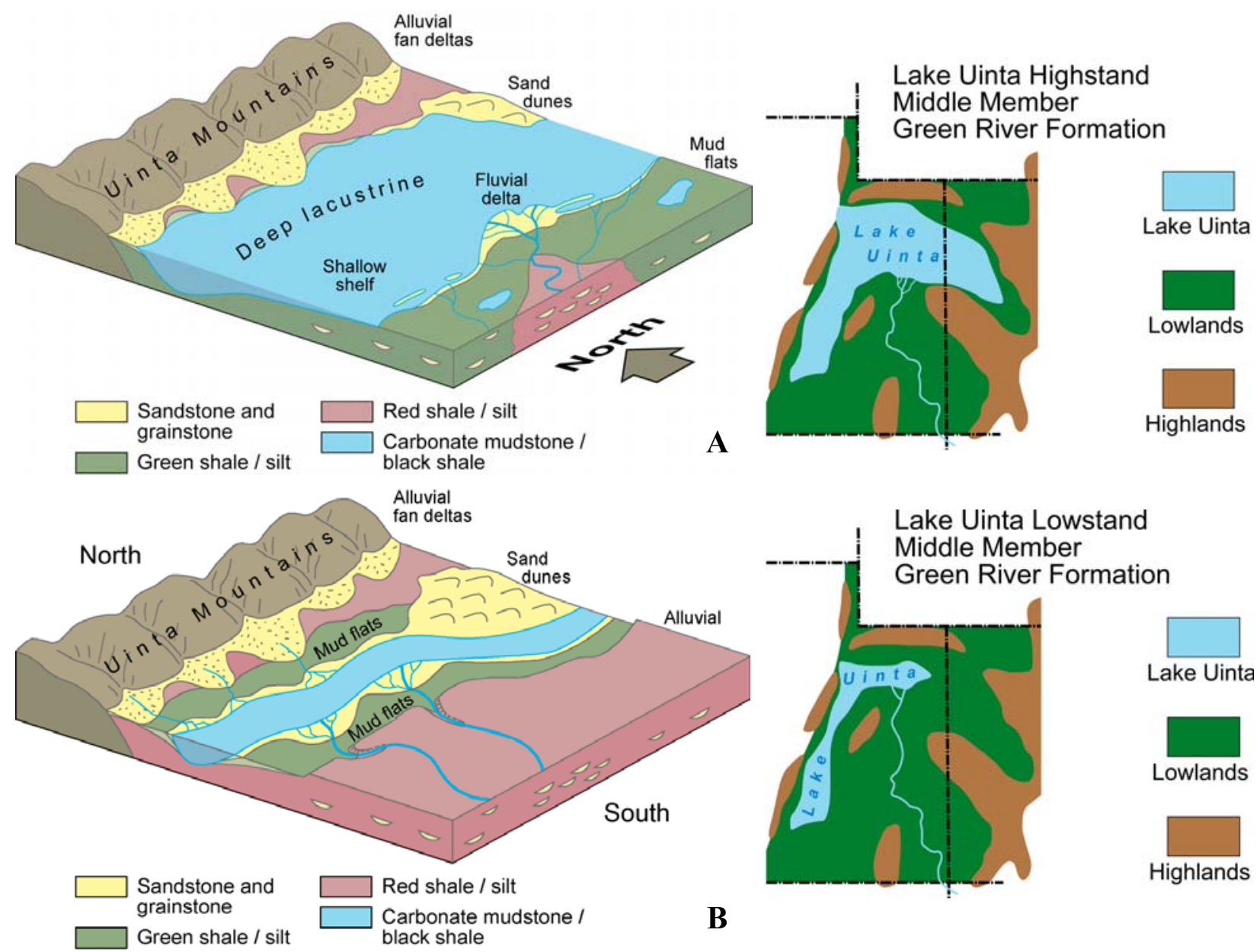

Figure 15. Diagrams showing the generalized depositional setting for Lake Uinta during high lake levels (A) and low lake levels (B). The Uinta Mountains were the source for the sediments in the northern portion of the lake while sediments in the southern portion of the lake were sourced from the much larger Four Corners area.

The U.S. Geological Survey (USGS) identifies two assessment units in the Green River Total Petroleum System within the Uinta Basin (Dubiel, 2003): (1) the deep Uinta Overpressured Continuous Oil Assessment Unit and (2) the Uinta Green River Conventional Oil and Gas Assessment Unit. The Uinta Green River Conventional Oil and Gas Assessment Unit is defined by the distribution of normally pressured oil and gas accumulations in the Green River Formation at depths less than 8500 feet (2600 m) (Dubiel, 2003).

The dominant sediment source for the Green River Formation in the Cedar Rim, Altamont, Bluebell, and Red Wash fields was to the north, while the sediment source for the greater Monument Butte area, Duchesne, Brundage Canyon, Sowers, Antelope Creek, and Uteland Butte fields was to the south (figures 1 and 15). As a result, the deposition and the resulting reservoir properties are significantly different between south-sourced and northsourced depositional systems. We divide the Uinta Green River Conventional Oil and Gas Assessment Unit into a Southern Green River Formation Uinta Basin Play and a Northern Green River Formation Uinta Basin Play. The greater Monument Butte field of the Southern Green River Formation Uinta Basin Play is discussed here. 
The southern shore of Lake Uinta was often very broad and flat, which resulted in laterally extensive transgressions and regressions of the shoreline in response to climatic and tectonic-induced rise and fall of the lake. The cyclic nature of Green River deposition in the central Uinta Basin resulted in numerous stacked deltaic deposits. Distributary-mouth bars, distributary channels, and nearshore bars are the primary producing reservoirs in the area.

\section{Monument Butte Field}

Monument Butte field, Duchesne County, Utah, is a stratigraphic updip pinchout along the gentle north-dipping flank of the Uinta Basin (figure 16) that produces from stacked, fluvial-deltaic channel and offshore bar sandstones in the Green River Formation (Lomax, 1993). The net reservoir thickness is 16 feet $(5 \mathrm{~m})$, which extends over a 21,000-acre ( $8500 \mathrm{ha})$ area. Porosity and permeability ranges from 10 to 20 percent and 25-30 millidarcies (md), respectively. The drive is solution gas and the initial water saturation was 30 to 35 percent (Lomax, 1993).

Monument Butte field was discovered in 1981, with the completion of the Lomax Exploration Company Monument Butte Federal No. 1-35 well, SE1/4SE1/4 section 25, T. 8 S., R. 16 E., Salt Lake Base Line and Meridian (SLBL\&M); initial flowing potential was 37 bbls of oil per day (BOPD) $\left(6 \mathrm{~m}^{3} / \mathrm{d}\right)$ and 19 thousand cubic feet of gas per day (MCFGPD) (0.5 MCMPD). The field currently has 456 producing (or shut-in) wells (Utah Division of Oil, Gas and Mining, 2003). The well spacing is 40 acres (16 ha). The original reservoir field pressure was 2150 pounds per square inch (psi) $(14,800 \mathrm{kpa})$; the present reservoir field pressure ranges from 600 to 1800 psi (4100-12,400 kpa) (Lomax, 1993).

Cumulative production as of November 1, 2003, was 22,030,880 bbls of oil $(3,502,909$ $\left.\mathrm{m}^{3}\right)$, 64 billion cubic feet of gas (BCFG) $(1.8 \mathrm{BCMG})$, and over 5 million bbls of water $(0.8$ million $\mathrm{m}^{3}$ ) (Utah Division of Oil, Gas and Mining, 2003). The original estimated primary recovery was 5 percent of the original oil in place (OOIP). With multiple waterflood projects the secondary recovery is expected to be 15 to 25 percent of the OOIP (Lomax, 1993).

\section{Optimal Drilling, Development, and Production Practices}

\section{Drilling Wells}

Development drilling in the greater Monument Butte area is relatively easy. Wells are typically drilled to a total depth of 6000 to 6500 feet $(2000-2200 \mathrm{~m})$ in the Green River Formation. Most wells take about six days to drill. Inland Production Company (Inland) currently operates about 750 wells and expects to drill 1200 more wells on 40 acre spacing over the next 20 years (60 wells per year). The development program has a very high success rate with approximately one well in 60 being plugged and abandoned during a year. Surface casing is set at about 300 feet $(100 \mathrm{~m})$ as per state requirement, and then the well is drilled to a total depth with a freshwater mud system. There are no high-pressure zones or significant lost circulation problems, even in the small, lenticular sandstone reservoirs. Eagle Services, a subsidiary of Inland, owns a drilling/workover rig and employs the drill crews. Having their own rig ensures availability when they need it and costs less than contracting (Michael Guinn, Inland Production Co., verbal communication, 2003). 


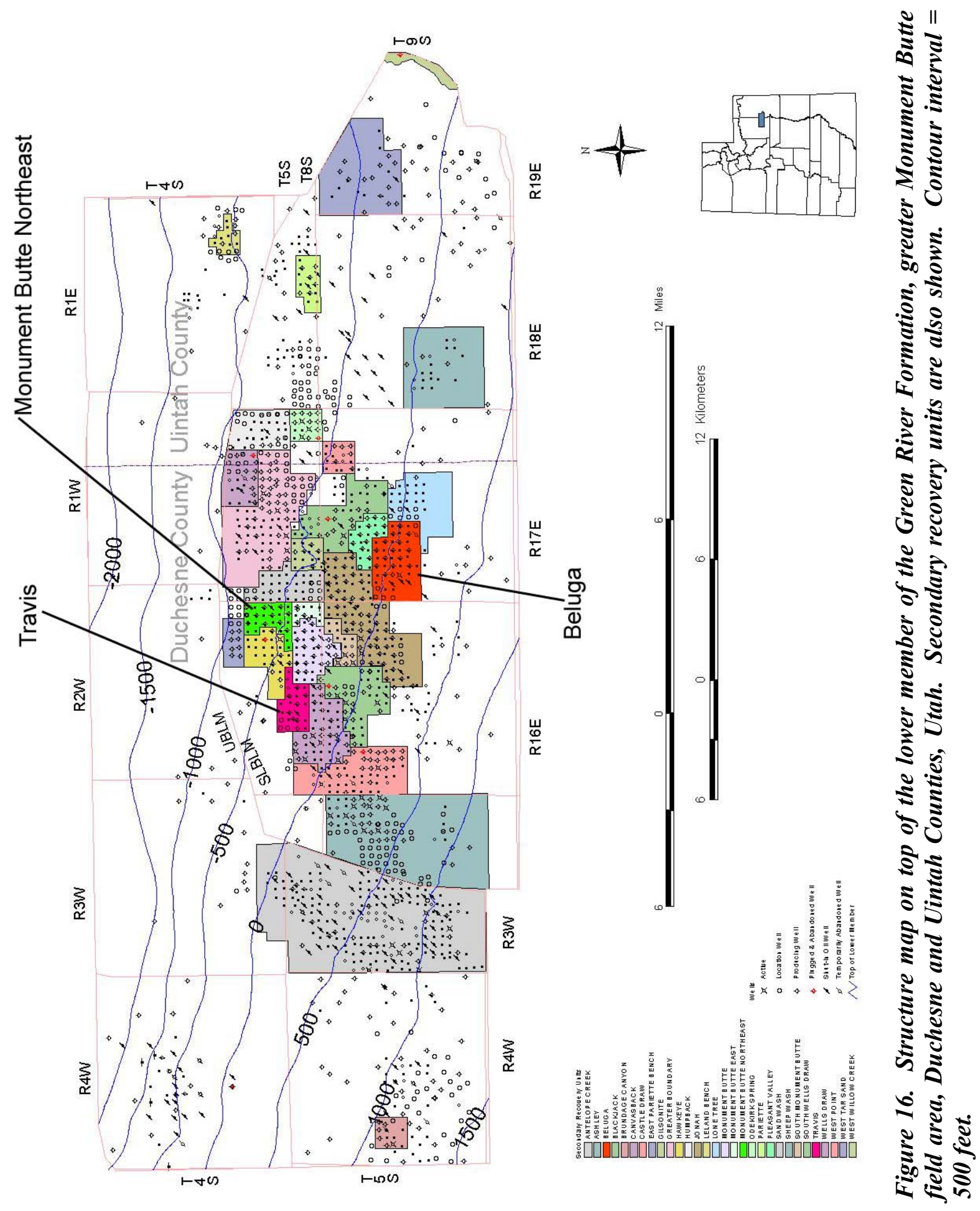




\section{Completing Wells}

The geophysical logging suite consists of: (1) gamma ray; (2) density and neutron porosity; and (3) resistivity. Mud-logging units were originally used while drilling, but are no longer required. Sandstone beds with more than 8 percent neutron porosity are selected for perforating with 40 shots per foot. The gross perforated interval can be as long as 2000 feet $(700 \mathrm{~m})$. Each bed, or closely spaced group of beds, are stimulated separately, resulting in four to five, but occasionally as many as nine, sand fracture treatments per well. The stimulation includes about 2500 to 4000 pounds (1100-1800 kg) of sand/perforated foot with an average of 80,000 pounds $(36,000 \mathrm{~kg})$ of sand per well. The typical treatment is pumped at a pressure of 1800 to 2000 psi $(12,000-14,000 \mathrm{kpa})$ with a maximum of $4200 \mathrm{psi}(29,000 \mathrm{kpa})$. The lowermost perforated bed or interval is treated first, then a composite bridge plug is set above the bed and the next bed is treated and a composite bridge plug is set above it. This procedure continues up the hole until all the perforated beds have been treated. The fracture fluids are then flowed back to the surface. The composite bridge plugs allow flow up the hole but not down. Most wells can be treated in a day.

Inland has their own frac (or holding) tanks, reducing the cost of the fracture treatments. Inland builds the battery (separator, lines, and storage tanks) before treating the well. As a result, the well can be placed on production as soon as the completion rig moves off location. Placing the well on production immediately ensures that the fracture treatment fluids that did not flow back are not left in the hole for an extended period where they can cause formation damage (Michael Guinn, Inland Production Co., verbal communication, 2003).

\section{Producing Wells and Waterflood Projects}

All completed wells are placed on primary production using artificial lift. The original reservoir pressure is near the bubble point pressure of the oil, therefore, the wells are converted relatively soon to secondary waterflooding to maintain reservoir pressure above bubble point, maximizing recovery. The waterflood uses an alternating injector - producer pattern on 40 -acre (16-ha) spacing. The size of waterflood units in the greater Monument Butte area varies, but most are about 1 to 2 square miles $\left(3-5 \mathrm{~km}^{2}\right)$ with 16 wells per section (a section is 1 square mile $\left.\left[2.6 \mathrm{~km}^{2}\right]\right)$. There are 1320 feet $(440 \mathrm{~m})$ between wells with one well drilled in the center of each 40-acre (16-ha) tract. A well that is scheduled to be an injector will be produced until the production rate drops to about 15 BOPD $\left(2 \mathrm{~m}^{3} / \mathrm{d}\right)$ and then is converted to injection. Most wells are on primary production for 1.5 years. Injection water is a combination of produced and culinary water with corrosion and scale inhibitors added. Currently, Inland is injecting about 3000 barrels of produced water/day $\left(500 \mathrm{~m}^{3} / \mathrm{d}\right)$ and 18,000 barrels $\left(3000 \mathrm{~m}^{3} / \mathrm{d}\right)$ of culinary water/day from Starvation Reservoir, about 18 miles $(29 \mathrm{~km})$ to the northwest. Typical injection pressure is from 1400 to 2000 psi (9700-14,000 kpa). The Inland waterflood program is in a relatively early stage and significant breakthrough of injected water has not occurred. As a result, the flood is monitored by well production rates, but there are no regular isolation tests conducted to monitor the flood at the bed scale (Michael Guinn, Inland Production Co., verbal communication, 2003). There are over 20 secondary recovery units in Monument Butte field. Three of these units (the Travis, Monument Butte Northeast, and Beluga) are discussed in the following sections. 
Travis waterflood unit: The Travis waterflood unit covers the southern half of section 28 and the northern half of section 33, T. 8 S., R. 16 E., SLBL\&M (figures 16 and 17). The major reservoirs in the Travis unit are sandstone beds of the Travis interval that were deposited in cutand-fill valleys on a gently northeast-dipping structure (figures 17 and 18). Secondary objectives are sandstone beds in the Castle Peak, Monument Butte, and Beluga intervals described in detail by Morgan and others (1999, 2003), Morgan and Bereskin (2003), and Morgan and Chidsey (2003). Thickness of the Travis sandstone can vary from more than 100 feet $(30 \mathrm{~m})$ to near zero in a neighboring well only 1320 feet $(400 \mathrm{~m})$ away (figures 17 and 18). In areas where cut-and-fill did not occur, less-productive marginal-lacustrine sandstone beds were deposited.

The Travis waterflood unit included nine active injection wells during 2002. The average daily injection of fresh/produced water was 444 barrels $\left(71 \mathrm{~m}^{3}\right)$ at an average injection pressure of 1505 psi (10,380 kpa) (Utah Division of Oil, Gas and Mining, 2002b). Water injection has increased oil production only moderately (figure 19). The complex internal heterogeneity of the Travis reservoir, such as turbidite channel, debris flow, and gravity-flow deposits, may result in poor injection efficiency and poor pressure communication between injector and producer wells (inadequate sweep efficiency).
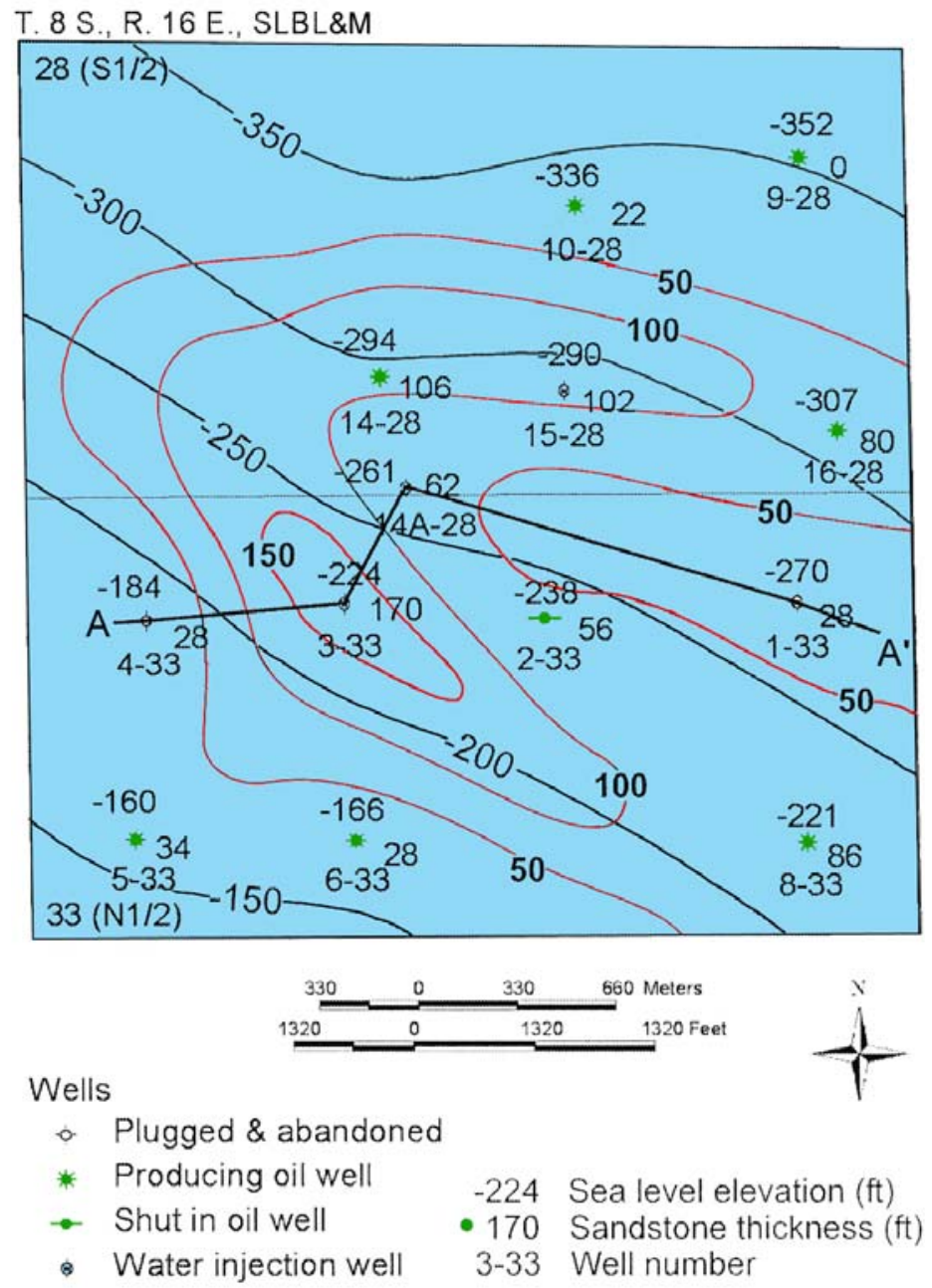

$-200-$ Structure contours $(\mathrm{Cl}=50 \mathrm{ft})$

-18- Isolith contours $(\mathrm{Cl}=50 \mathrm{ft})$
Figure 17. Structure map (black contours) on top of a log marker in the upper portion of the Travis reservoir (see figure 18), Travis waterflood unit; datum is sea level. Isopach map of sandstone in the Travis reservoir with $>10$ percent density log porosity is shown with red contours. Cross section $A-A$ ' is figure 18. 


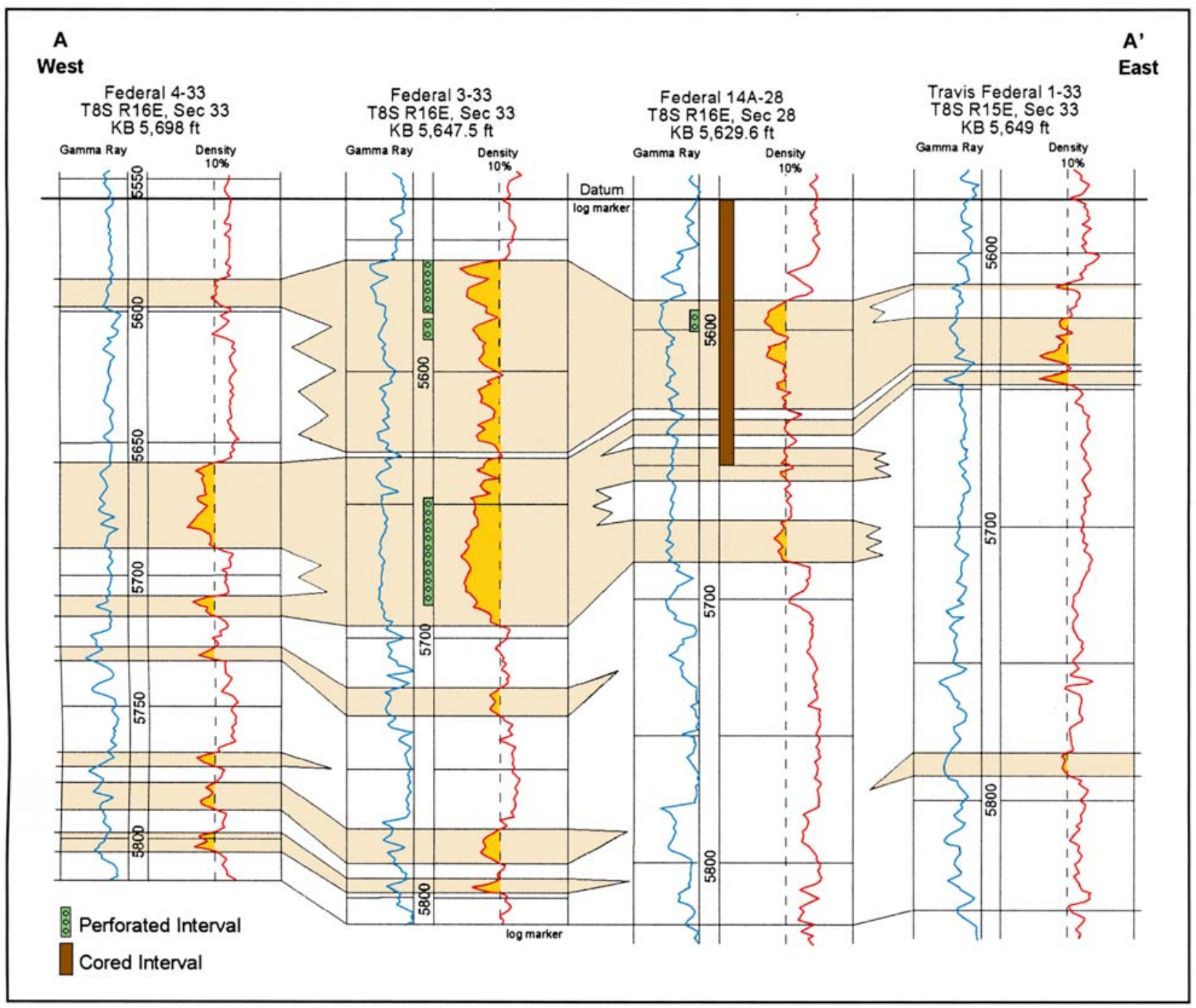

Figure 18. West-to-east cross section of the Travis interval in the Travis waterflood unit. Sandstone with $>10$ percent density log porosity is shaded orange. See figure 17 for location of cross section and an isopach map of the Travis sandstone beds.

Monument Butte Northeast waterflood unit: The Monument Butte Northeast waterflood unit covers all of section 25, and parts of sections 24 and 26, T. 8 S., R. 16 E., SLBL\&M (figures 16 and 20). The Monument Butte reservoir consists of amalgamated, stacked, channel-sandstone deposits on a gently northeast-dipping structure (figure 20 and 21). The MGR $7 \mathrm{~b}$ bed (described by Morgan and others, 1999, 2003; Morgan and Bereskin, 2003; and Morgan and Chidsey, 2003) is responsible for about 70 percent of the oil production from the Monument Butte Northeast unit (figure 21). However, there are 27 other beds that have been perforated in one or more wells in the unit (figure 21). Secondary objectives are sandstone beds in the Castle Peak, Travis, and Beluga intervals. Most wells are perforated in the Monument Butte reservoir, also known as the Douglas Creek B, C, and D sands (Morgan and Bereskin, 2003), which is the primary objective. 


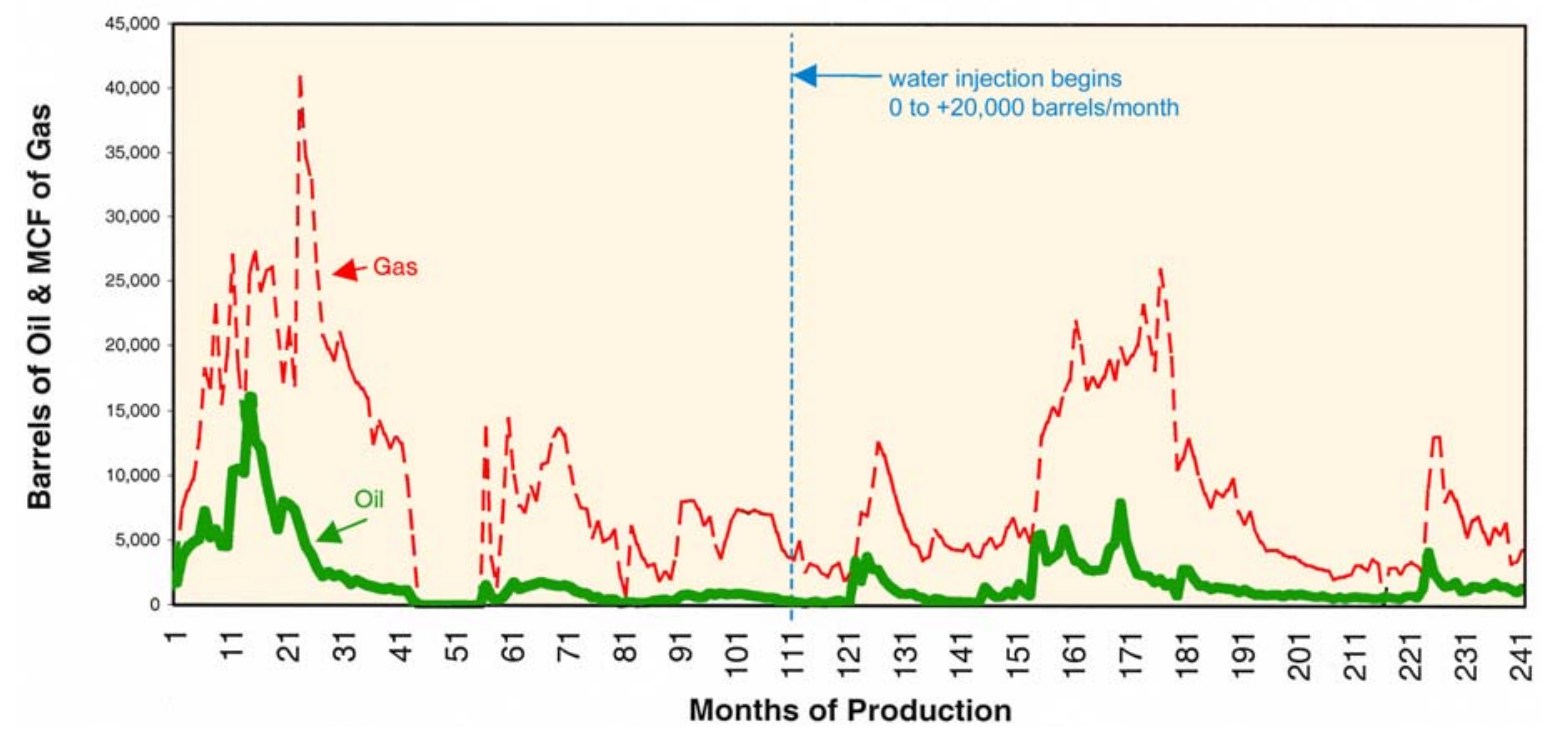

Figure 19. Monthly oil and gas produced in the Travis waterflood unit from December 31, 1982, through December 31, 2002. Data source: Inland Production Resources.

Figure 20. Structure map (black contours) on top of the MGR 7 marker (top of Monument Butte interval), Monument Butte Northeast waterflood unit; datum is sea level. Isopach map of the MGR $7 b$ sandstone bed, the most productive bed in the unit, is shown with red contours. Cross section B-B' is figure 21.

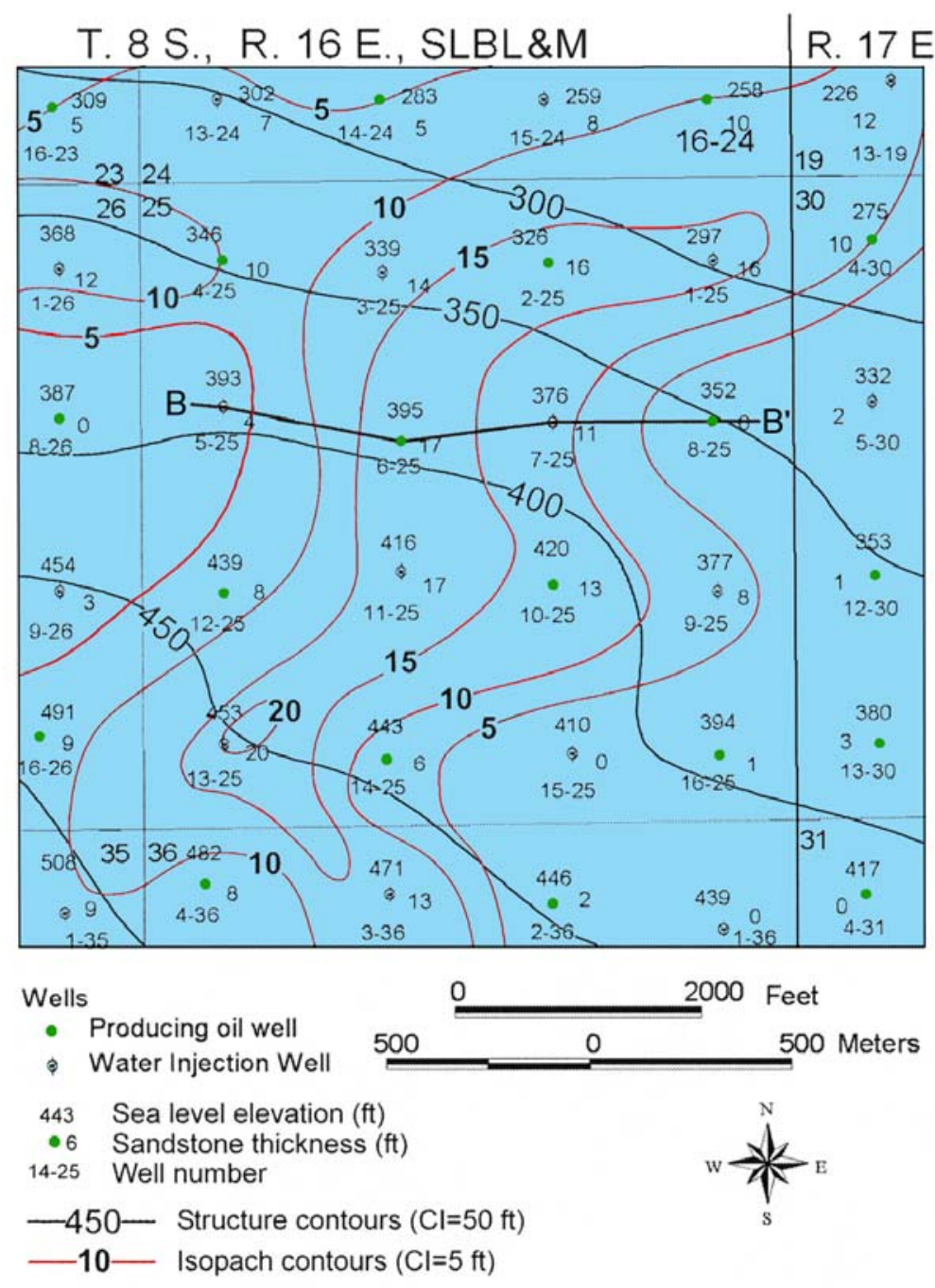




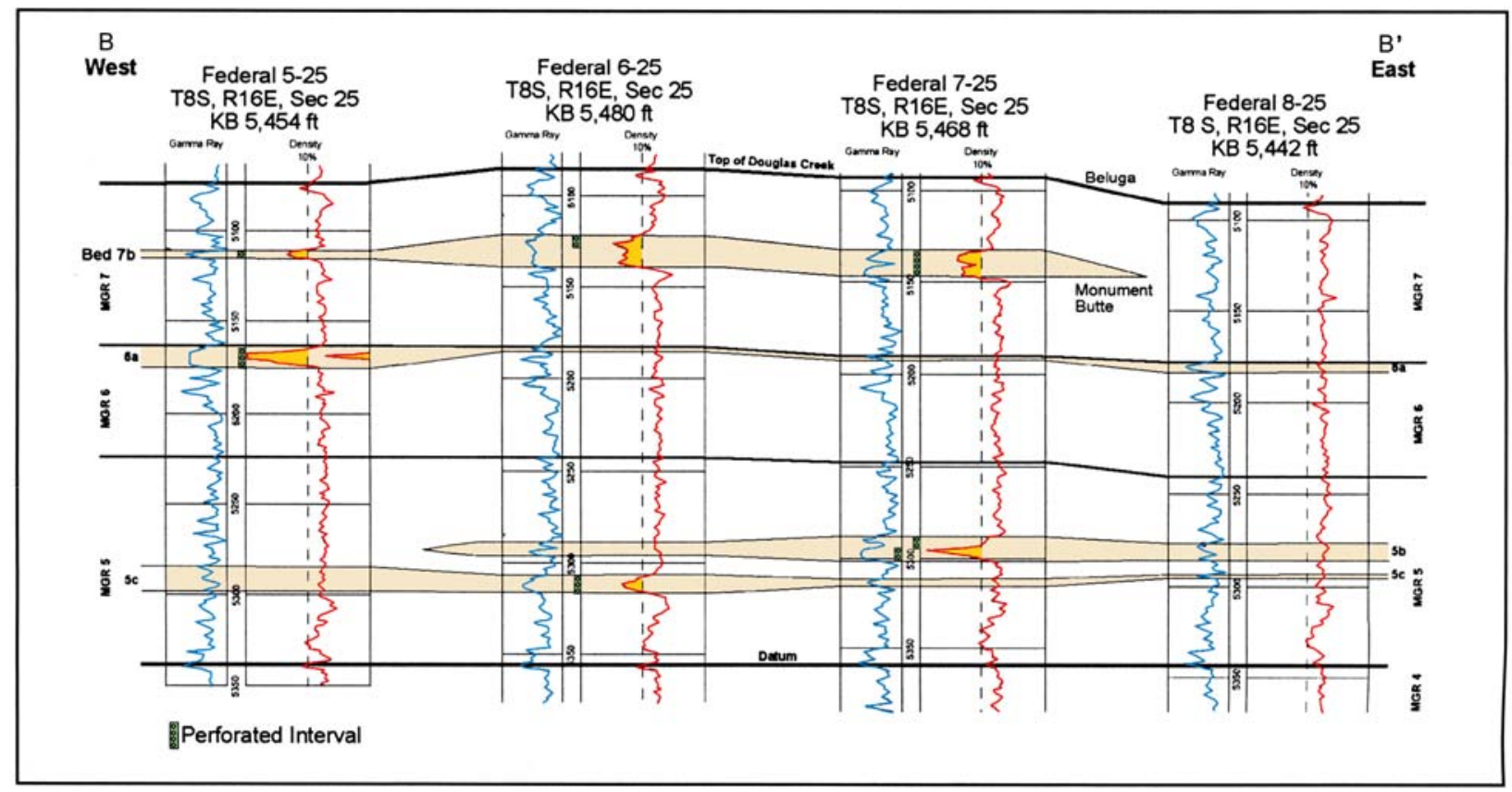

Figure 21. West-to-east cross section of a portion of the Monument Butte interval in the Monument Butte Northeast waterflood unit. Sandstone with $>10$ percent density log porosity is shaded orange. See figure 20 for location of the cross section and an isopach map of the MGR $7 b$ bed.

The Monument Butte Northeast waterflood unit included 11 active injection wells during 2002. The average daily injection of fresh/produced water was 651 barrels $\left(104 \mathrm{~m}^{3}\right)$ at an average injection pressure of 1339 psi (9232 kpa) (Utah Division of Oil, Gas and Mining, 2002 b). Initial water injection increased oil production significantly (figure 22). Eventually, as water injection occurred, the reservoir pressure was raised above the bubble point as indicated by the reduction in the gas-to-oil ratio.

Beluga waterflood unit: The Beluga waterflood unit covers the southern half of sections 7 and 8, and all of sections 17 and 18, T. 9 S., R. 17 E., SLBL\&M (figures 16 and 23). In the Beluga unit, the Monument Butte reservoir is the primary productive interval, but most wells in the unit also produce from sandstone beds in the MGR 13 log-cycle of the Beluga interval (described by Morgan and others, 1999, 2003; Morgan and Bereskin, 2003; and Morgan and Chidsey, 2003). The Beluga reservoir consists of lenticular channel sandstone beds on a gently north- to northeast-dipping structure (figures 23 and 24).

The Beluga waterflood unit included 15 active injection wells during 2002. The average daily injection of fresh/produced water was 806 barrels $\left(104 \mathrm{~m}^{3}\right)$ at an average injection pressure of 1791 psi (12,350 kpa) (Utah Division of Oil, Gas and Mining, 2002b). After 15 months, water injection increased oil production significantly (figure 25). Once injection began, the reservoir pressure was raised above the bubble point as indicated by the reduction in the gas-to-oil ratio. 


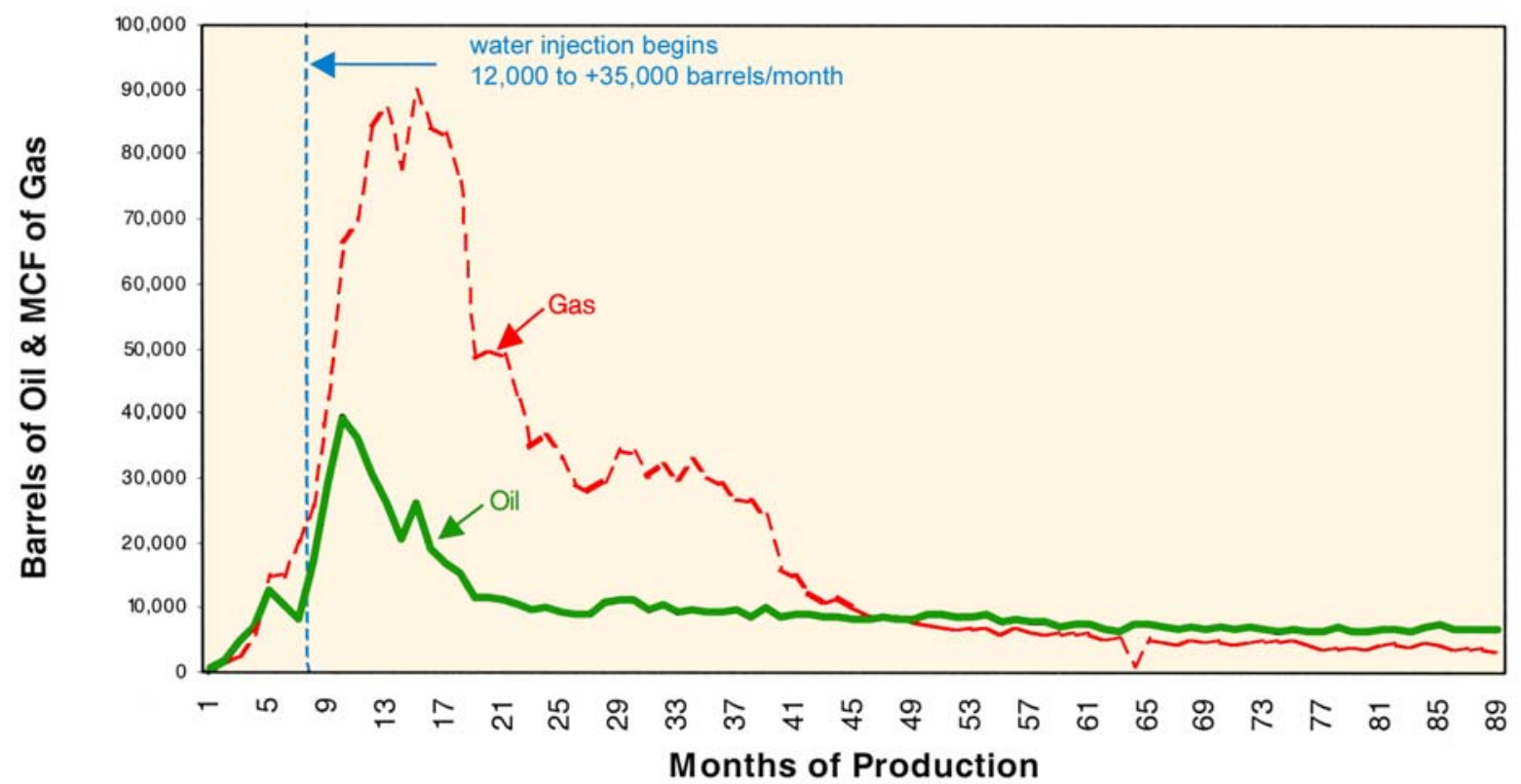

Figure 22. Monthly oil and gas produced in the Monument Butte Northeast waterflood unit from August 31, 1995, through December 31, 2002. Data source: Inland Production Resources.

Figure 23. Structure map (black contours) on top of the MGR 12 marker, Beluga waterflood unit; datum is sea level. Isopach map of sandstone with $>10$ percent density log porosity in the MGR 13 log cycle in the Beluga interval is shown with red contours. Cross section $C-C$ ' is figure 24.

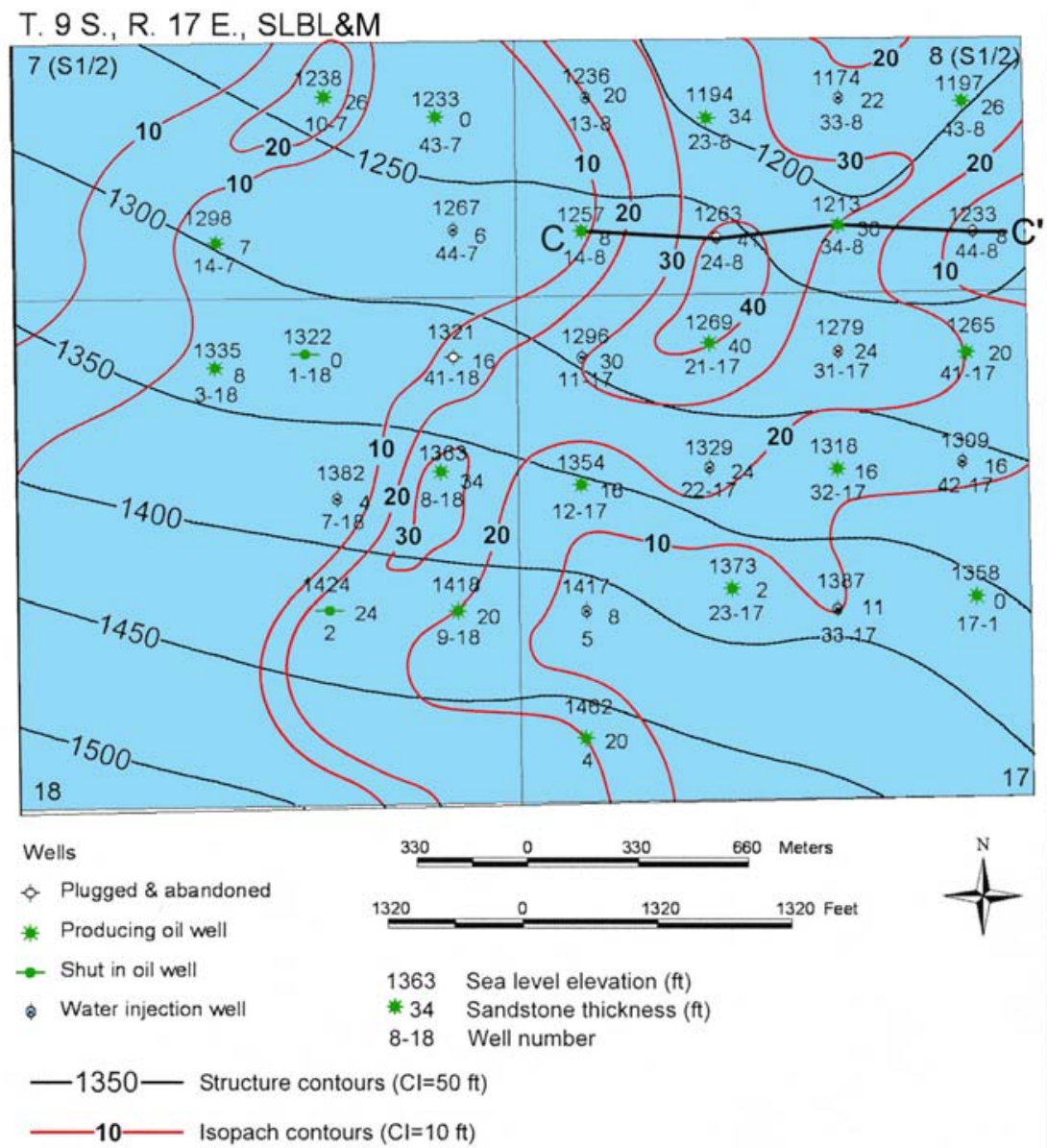




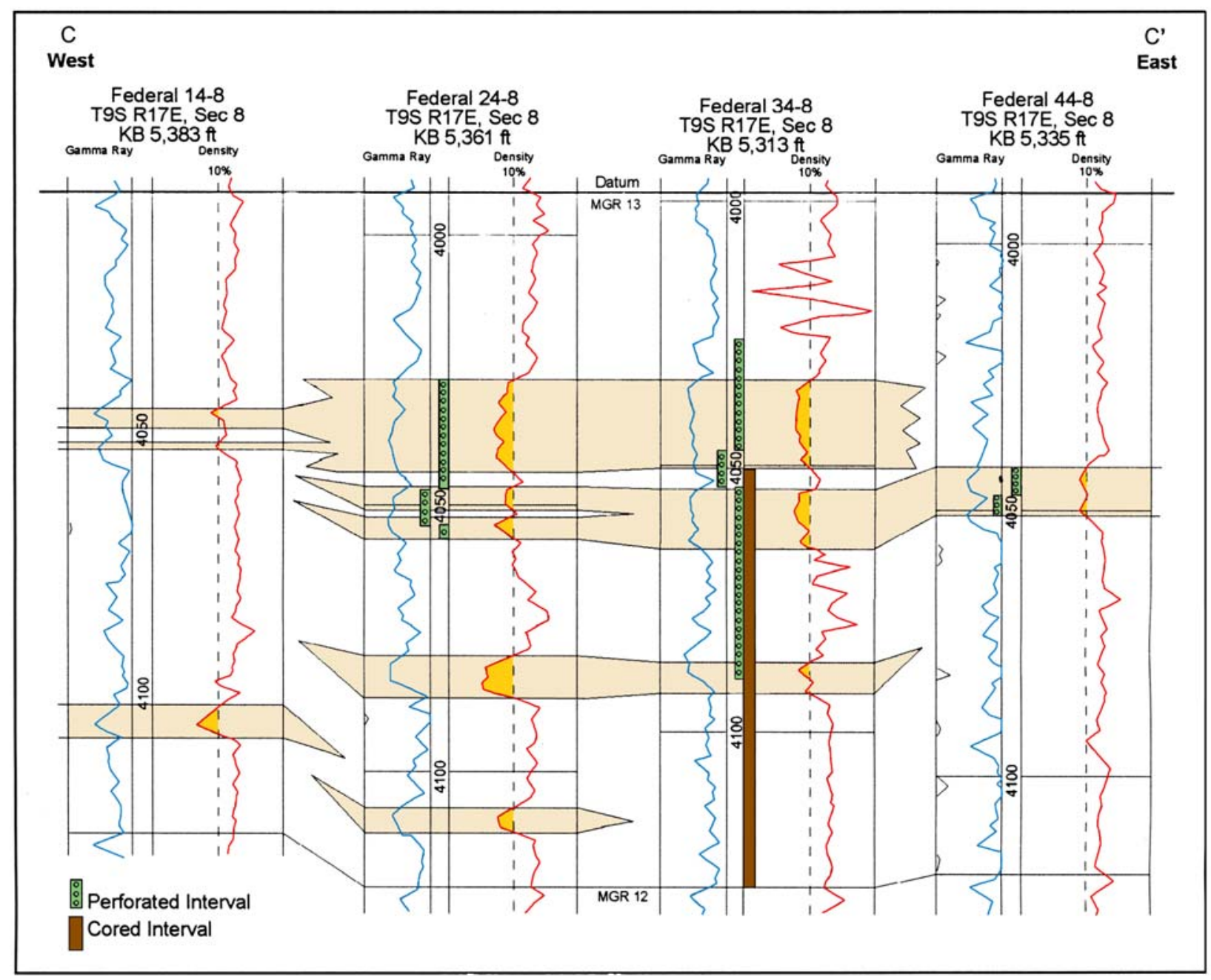

Figure 24. West-to-east cross section of the MGR 13 log-cycle in the Beluga interval in the Beluga waterflood unit. Sandstone with $>10$ percent density log porosity is shaded orange. See figure 23 for location of cross section and an isopach map of the MGR 13 sandstone with $>10$ percent density log porosity.

\section{Recompleting Wells}

The original completion technique involved selecting beds to be perforated in each well based on the well logs, but without regard for plans for the longer-term waterflood. As a result, some producing wells were perforated in beds that were not perforated in the injection wells, and some injection wells were perforated in beds that were not open in the neighboring producing wells. During 2003, Inland recompleted the producing wells, perforating all beds that are productive in the waterflood unit. In 2004, Inland plans to recomplete the injection wells and perforate all beds that are productive within the unit (Michael Guinn, Inland Production Co., verbal communication, 2003). 


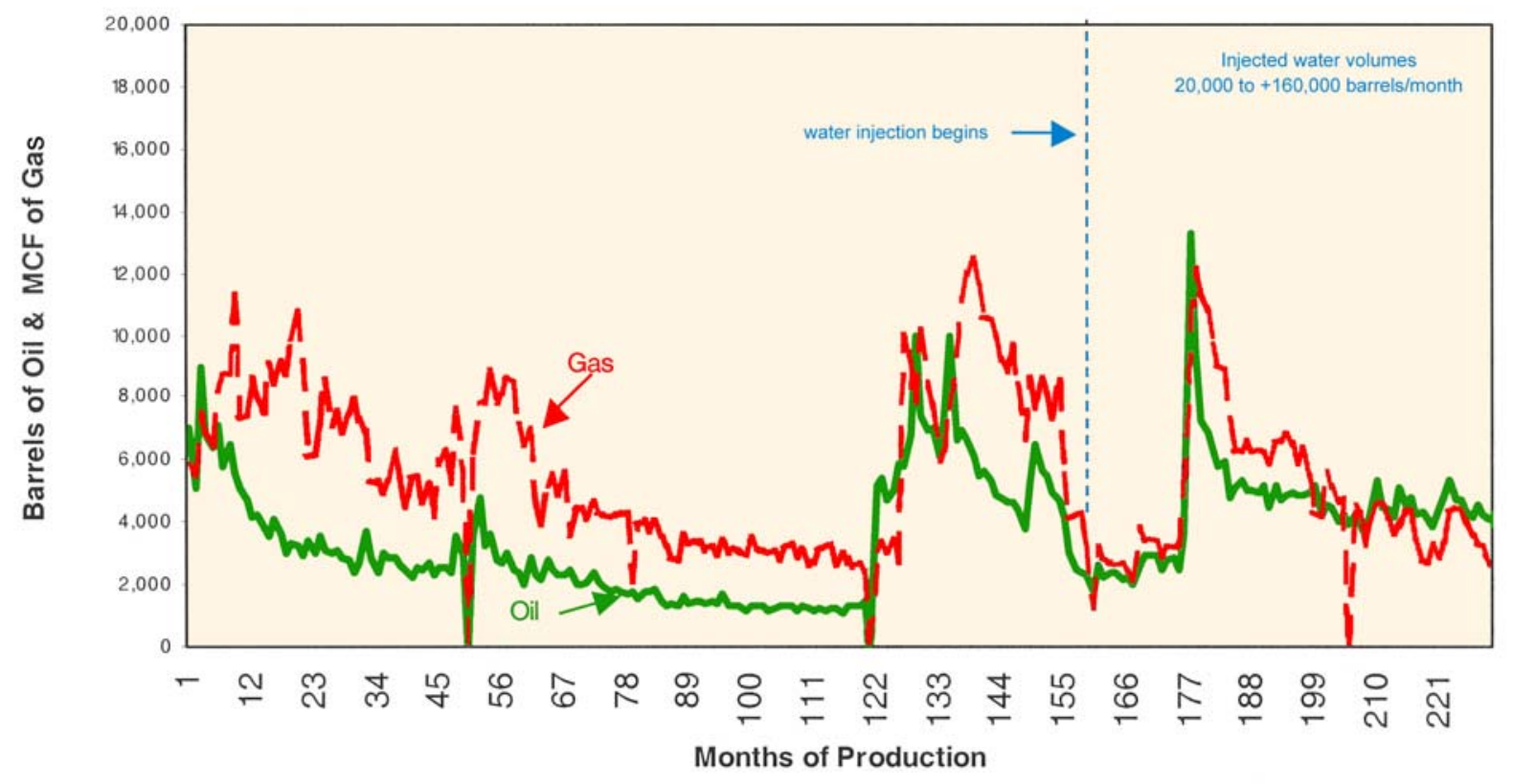

Figure 25. Monthly oil and gas produced in the Beluga waterflood unit from January 31, 1984, through December 31, 2002. Data source: Inland Production Resources.

\section{Environmental Issues}

The greater Monument Butte field area has several environmental issues, such as Mountain Plovers and raptor nests, which cannot be avoided. A field operator should hire people who can work closely with the regulatory agencies involved. In order to keep crews and rigs busy and ensure the development program is progressing, it is important to have several drilling options available so if environmental issues delay some plans there are still other activities that can be pursued.

Inland and other operators in the Uinta Basin have expressed concern over a conflict of interest that can arise in dealing with wildlife issues. For example, while studying raptors in an area, an operator along with Utah Division of Wildlife Resources personnel might work to improve the habitat, such as building artificial raptor nests, but if the work is successful and more raptors are attracted to the area, then the operator's activity near those nests can be greatly restricted (Michael Guinn, Inland Production Co., verbal communication, 2003).

\section{TECHNOLOGY TRANSFER}

The Utah Geological Survey (UGS) is the Principal Investigator and prime contractor for the PUMPII project. All play maps, reports, databases, and other deliverables produced for the PUMPII project will be published as interactive, menu-driven digital (web-based and compact disc) and hard-copy formats by the UGS for presentation to the petroleum industry. Syntheses and highlights will be submitted to refereed journals, as appropriate, such as the American Association of Petroleum Geologists (AAPG) Bulletin and Journal of Petroleum Technology, and to trade publications such as the Oil and Gas Journal. 
Survey Notes provides non-technical information on contemporary geologic topics, issues, events, and ongoing UGS projects to Utah's geologic community, educators, state and local officials and other decision makers, and the public. Survey Notes is published three times yearly. Single copies are distributed free of charge and reproduction (with recognition of source) is encouraged. The UGS maintains a web site on the Internet, http://geology.utah.gov. The UGS site includes a page under the heading Utah Geology/Oil and Energy, which describes the UGS/DOE cooperative studies (PUMPII, Paradox Basin [two projects], Ferron Sandstone, Bluebell field, Green River Formation), and has a link to the DOE web site. Each UGS/DOE cooperative study also has its own separate page on the UGS web site. The PUMPII project page, http://geology.utah.gov/emp/pump/index.htm, contains: (1) a project location map; (2) a description of the project; (3) a reference list of all publications that are a direct result of the project; and (4) quarterly technical progress reports.

The technology-transfer plan included the formation of a Technical Advisory Board and a Stake Holders Board. The Technical Advisory Board advises the technical team on the direction of study, reviews technical progress, recommends changes and additions to the study, and provides data. The Technical Advisory Board is composed of field operators from the oilproducing provinces of Utah that may also extend into Wyoming or Colorado. This board ensures direct communication of the study methods and results to the operators. The Stake Holders Board is composed of groups that have a financial interest in the study area including representatives from the State of Utah (School and Institutional Trust Lands Administration and Utah Division of Oil, Gas and Mining) and the Federal Government (Bureau of Land Management and Bureau of Indian Affairs). The members of the Technical Advisory and Stake Holders Boards receive all quarterly technical reports and copies of all publications, and other material resulting from the study. Board members will also provide field and reservoir data, especially data pertaining to best practices.

An abstract was submitted to the AAPG on basin-wide correlation of Green River Formation plays and subplays in the Uinta Basin in Utah. If the paper is accepted, it will be presented during the 2004 AAPG Rocky Mountain Section Meeting in Denver, Colorado. Another abstract submitted to the AAPG on outcrop analogs for major oil reservoirs in Utah has been accepted; the paper will be presented at a poster session on April 20 during the 2004 AAPG annual meeting in Dallas, Texas. This information will also be released on the UGS project Internet web page.

\section{CONCLUSIONS}

A combination of depositional and structural events created the right conditions for oil generation and trapping in the major oil-producing provinces (Paradox Basin, Uinta Basin, and thrust belt) in Utah and adjacent areas in Colorado and Wyoming. Oil plays are specific geographic areas with petroleum potential due to favorable source rock, migration paths, reservoir characteristics, and other factors.

Utah is fortunate in that representative outcrop analogs for each major oil play are present in or near the thrust belt, Uinta Basin, and Paradox Basin. Production-scale analogs provide an excellent view, often in 3D, of reservoir-facies characteristics (geometry, distribution, and so forth) and the nature of boundaries contributing to the overall heterogeneity of reservoir rocks. Outcrop analogs can be used as a "template" for evaluation of data from 
conventional core, geophysical and petrophysical logs, and seismic surveys. When combined with subsurface geological and production data, analog models improve development drilling and production strategies, reservoir-simulation models, reserve calculations, and design and implementation of secondary/tertiary oil recovery programs and other best practices used in the oil fields of Utah and vicinity.

One of the most prolific oil reservoirs in the Utah/Wyoming thrust belt province is the Jurassic Twin Creek Limestone that was deposited in a shallow-water embayment south of the main body of a Middle Jurassic sea that extended from Canada to southern Utah. Traps form on discrete subsidiary closures along major ramp anticlines where the low-porosity Twin Creek is extensively fractured. The seals for the producing horizons are the overlying argillaceous and clastic beds, and non-fractured units within the Twin Creek Limestone. Most oil and gas production is from perforated intervals in the Watton Canyon, upper Rich, and Sliderock Members. These members have little to no primary porosity in the producing horizons but exhibit secondary porosity in the form of fracturing.

The best outcrop analogs for the Twin Creek Limestone are found west of Anschutz Ranch field at Devils Slide on the Crawford thrust plate and southwest of Lodgepole field near the town of Peoa, Utah, on the Absaroka thrust plate (?). Closely spaced rhombic and rectilinear fracture patterns developed on bedding planes and within dense, homogeneous nonporous (in terms of primary porosity) limestone beds of the Rich and Watton Canyon Members. The contact with the basal siltstone units (where fractures are sealed) of the overlying members set up the Rich and Watton Canyon for hydrocarbon trapping and production. Thin-bedded siltstone within the Rich and Watton Canyon Members, also observed in outcrop, creates additional reservoir heterogeneity. Identification and correlation of these barriers and baffles to fluid flow, and recognizing fracture set orientations in individual Twin Creek reservoirs in the thrust belt is critical to understanding their effects on production rates, petroleum movement pathways, and horizontal well plans.

The Mississippian Leadville Limestone is a major oil and gas reservoir in the Paradox Basin of Utah and Colorado. The Leadville was deposited on a shallow, open-marine, carbonate-shelf which, during Late Mississippian time, was subjected to subaerial erosion resulting in formation of a lateritic regolith. This regolith and associated carbonate dissolution are important factors in Leadville reservoir potential. Hydrocarbons are produced from basement-involved, northwest-trending structural traps with closure on both anticlines and faults. Three factors create reservoir heterogeneity within productive zones: (1) variations in carbonate fabrics and facies; (2) diagenesis (including karstification); and (3) fracturing.

Excellent outcrops of Leadville-equivalent rocks are found along the south flank of the Uinta Mountains, Utah. They provide production-scale analogs of facies characteristics, geometry, distribution, and the nature of boundaries contributing to the overall heterogeneity of Leadville reservoir rocks. For example, the Madison Limestone is a fine- to coarse-crystalline, cherty limestone with some dolomite. Limestone units commonly contain numerous caverns, sinkholes, and local zones of solution breccia and vugs. Sections can have high heterogeneity due to stylolites, jointing, and fractures. Possible buildups or mud mounds comparable to Waulsortian facies are also found in the Madison.

To reduce operating costs, enhance production, and increase ultimate recovery from greater Monument Butte field of the Southern Green River Formation Uinta Basin Play, the following completion and reservoir management practices should be employed: (1) the operators should own the drilling rigs ensuring availability and that costs are less than 
contracting; (2) the operators should purchase frac tanks to reduce the cost of the fracture treatments; (3) sandstone beds with more than 8 percent neutron porosity should be selected for perforation, and stimulation of individual beds should begin with the lowermost perforated bed; (4) completed wells should be placed on primary production using artificial lift; (5) wells should be converted relatively soon to secondary waterflooding to maintain reservoir pressure above the bubble point in order to maximize oil recovery; (6) waterflood units should be developed using an alternating injector - producer pattern on 40-acre (16-ha) spacing; (7) producing wells should be recompleted by perforating all beds that are productive in the waterflood unit; (8) operators should hire people who can work closely with the regulatory agencies involved; and (9) several drilling options should be available so if environmental issues delay some parts, there are other drilling activities that can be pursued.

\section{ACKNOWLEDGMENTS}

Funding for this ongoing research was provided as part of the DOE Preferred Upstream Management Program (PUMP II) of the U.S. Department of Energy, National Petroleum Technology Office, Tulsa, Oklahoma, contract number DE-FC26-02NT15133. The Contracting Officer's Representative is Rhonda Jacobs.

Michael Guinn, Vice President of Operations, Inland Production Company, Myton, Utah, provided excellent information on best practices used in the greater Monument Butte field area.

Jim Parker and Vicky Clarke of the UGS prepared the figures. This report was reviewed by Dave Tabet and Mike Hylland of the UGS. Cheryl Gustin, UGS, formatted the manuscript.

\section{REFERENCES}

Ahr, W.M., 1989, Mississippian reef facies in the Southwest - a spectrum of variations in depositional style and reservoir characteristics: Ft. Worth Geological Society and Texas Christian University, Symposium on the Petroleum Geology of Mississippian Carbonates in North Central Texas, p. 1-19.

Baars, D.L., 1966, Pre-Pennsylvanian paleotectonics - key to basin evolution and petroleum occurrences in the Paradox Basin, Utah and Colorado: American Association of Petroleum Geologists Bulletin, v. 50, no. 10, p. 2082-2111.

Bruce, C.L., 1988, Jurassic Twin Creek Formation - a fractured limestone reservoir in the overthrust belt, Wyoming and Utah, in Goolsby, S.M., and Longman, M.W., editors, Occurrence and petrophysical properties of carbonate reservoirs in the Rocky Mountain region: Rocky Mountain Association of Geologists, p. 105-120.

Bryant, Bruce, 1990, Geologic map of the Salt Lake City 30' x 60' quadrangle, north-central Utah, and Uinta County, Wyoming: U.S. Geological Survey Miscellaneous Investigation Series Map I-1944, 1:100,000. 
Conner, D.C., and Covlin, R.J., 1977, Development geology of Pineview field, Summit County Utah: Wyoming Geological Association, $29^{\text {th }}$ Annual Field Conference, p. 639-650.

Coogan, J.C., 1999, Progress report geologic map of the Devils Slide quadrangle, Morgan and Summit Counties, Utah: unpublished 1:24,000 map used to compile the Ogden 30' x 60' quadrangle, Utah Geological Survey Open-file Report 380, 1:100,000.

Dixon, J.S., 1982, Regional structural synthesis, Wyoming salient of western overthrust belt: American Association of Petroleum Geologists Bulletin, v. 66, no. 10, p. 1560-1580.

Doelling, H.H., 2000, Geology of Arches National Park, Grand County, Utah, in Sprinkel, D. A., Chidsey, T.C., Jr., and Anderson, P.B., editors, Geology of Utah's parks and monuments: Utah Geological Association Publication 28, p. 11-36.

Dubiel, R.F., 2003, Geology, depositional models, and oil and gas assessment of the Green River total petroleum system, Uinta-Piceance province, eastern Utah and western Colorado, in U.S. Geological Survey Uinta-Piceance Assessment Team, compilers, Petroleum Systems and Geologic Assessment of Oil and Gas in the Uinta-Piceance province, Utah and Colorado: U.S. Geological Survey Digital Data Series DDS-69-B.

Energy Information Administration, 2001, U.S. crude oil, natural gas, and natural gas liquids reserves - 2000 annual report: U.S. Department of Energy DOE/EIA-0216 (2000), p. 20.

Fouret, K.L., 1996, Depositional and diagnetic environment of the Mississippian Leadville Limestone at Lisbon field, Utah, in Huffman, A.C., Jr., Lund, W.R., and Godwin, L.H., editors, Geology and resources of the Paradox Basin: Utah Geological Association Publication 25, p. 129-138.

Harry, D.L., and Mickus, K.L., 1998, Gravity constraints on lithopheric flexure and the structure of the late Paleozoic Ouachita orogen in Arkansas and Oklahoma south-central North America: Tectonics, v. 17, no. 2, p. 187-202.

Hintze, L.F., 1993, Geologic history of Utah: Brigham Young University Studies Special Publication 7, 202 p.

Imlay, R.W., 1967, Twin Creek Limestone (Jurassic) in the Western Interior of the United States: U.S. Geological Survey Professional Paper 540, 105 p.

---1980, Jurassic paleobiogeography of the conterminous United States in its continental setting: U.S. Geological Survey Professional Paper 1062, 134 p.

Kinney, D.M., 1955, Geology of the Uinta River-Brush Creek area, Duchesne and Uintah Counties, Utah: U.S. Geological Survey Bulletin 1007, 185 p. 
Kluth, C.F., 1986, Plate tectonics of the Ancestral Rocky Mountains: American Association of Petroleum Geologists Memoir 41, p. 353-369.

Kluth, C.F., and Coney, P.J., 1981, Plate tectonics of the Ancestral Rocky Mountains: Geology, v. 9 , p. 10-15.

Kocurek, G., and Dott, R.H., Jr., 1983, Jurassic paleogeography and paleoclimate of the central and southern Rocky Mountains region, in Reynolds, M.W., and Dolly, E.D., editors, Symposium on Mesozoic paleogeography of west-central U.S.: Society for Sedimentary Geology (SEPM), Rocky Mountain Section, p. 101-116.

Lamerson, P.R., 1982, The Fossil Basin area and its relationship to the Absaroka thrust fault system, in Powers, R.B., editor, Geologic studies of the Cordilleran thrust belt: Rocky Mountain Association of Geologists, v. 1, p. 279-340.

Lomax, J.D., 1993, Monument Butte, in Hill, B.G., and Bereskin, S.R., editors, Oil and gas fields of Utah: Utah Geological Association Publication 22, non-paginated.

Morgan, C.D., 1993, Mississippian Leadville Limestone, in Hjellming, C.A., editor, Atlas of major Rocky Mountain gas reservoirs: New Mexico Bureau of Mines and Mineral Resources, p. 94.

Morgan, C.D., and Bereskin, S.R., 2003, Characterization of petroleum reservoirs in the Eocene Green River Formation, central Uinta Basin, Utah: The Mountain Geologist, v. 40, no. 4, p. 111-127.

Morgan, C.D., and Chidsey, T.C., Jr., 2003, Major oil plays in Utah and vicinity: Utah Geological Survey, unpublished quarterly technical progress report to the U.S. Department of Energy for the period 7/1/03 through 9/30/03, $42 \mathrm{p}$.

Morgan, C.D., Chidsey, T.C., Jr., Hanson, J.A., McClure, K.P., Weller, K., Bereskin, S.R., Deo, M.D., and Yeager, R., 1999, Reservoir characterization of the lower Green River Formation, southwest Uinta Basin, Utah: Utah Geological Survey, unpublished biannual technical progress report to the U.S. Department of Energy for the period 10/1/98 through 3/31/99, $11 \mathrm{p}$.

Morgan, C.D., Chidsey, T.C., Jr., McClure, K.P., Bereskin, S.R., and Deo, M.D., 2003, Reservoir characterization of the lower Green River Formation, southwest Uinta Basin, Utah: Utah Geological Survey Open-File Report 411, CD-ROM, 140 p.

Parker, J.W., and Roberts, J.W., 1963, Devonian and Mississippian stratigraphy of the central part of the Colorado Plateau: Four Corners Geological Society, $4^{\text {th }}$ Field Conference Guidebook, p. 31-60.

Parra, J.O., and Collier, H.A., 2000, Characterization of fractured zones in the Twin Creek reservoir, Lodgepole field, Utah-Wyoming overthrust belt: Petrophysics, v. 41, no. 5, p. 
$351-362$.

Rowley, P.D., and Hansen, W.R., 1979, Geologic map of the Split Mountain quadrangle, Uintah County, Utah: U.S. Geological Survey Map GQ-1515, scale 1:24,000.

Royse, Frank, Jr., Warner, M.A., and Reese, D.L., 1975, Thrust belt structural geometry and related stratigraphic problems, Wyoming-Idaho-Northern Utah, in Bolyard, D.W., editor, Symposium on deep drilling frontiers of the central Rocky Mountains: Denver, Colorado, Rocky Mountain Association of Geologists, p. 41-54.

Smouse, DeForrest, 1993, Lisbon, in Hill, B.G., and Bereskin, S.R., editors, Oil and gas fields of Utah: Utah Geological Association Publication 22, non-paginated.

Sprinkel, D.A., and Chidsey, T.C., Jr., 1993, Jurassic Twin Creek Limestone, in Hjellming, C. A., editor, Atlas of major Rocky Mountain gas reservoirs: New Mexico Bureau of Mines and Mineral Resources, p. 76.

Stearns, D.W., 1984, Fractured reservoir analysis school: American Association of Petroleum Geologists, Course Notes, non-paginated.

Stevenson, G.M., and Baars, D.L., 1987, The Paradox - a pull-apart basin of Pennsylvanian age, in Campbell, J.A., editor, Geology of Cataract Canyon and vicinity: Four Corners Geological Society, $10^{\text {th }}$ Field Conference, p. 31-55.

Utah Division of Oil, Gas and Mining, 2002a, Oil and gas production report, December 2002: non-paginated.

---2002b, Utah annual injection report, 2002: 5 p.

---2003, Oil and gas production report, October 2003: non-paginated.

Welsh, J.E., and Bissell, H.J., 1979, The Mississippian and Pennsylvanian (Carboniferous) Systems in the United States-Utah: U.S. Geological Survey Professional Paper 1110Y, $35 \mathrm{p}$.

Wilson, J.L., 1975, Carbonate facies in geologic history: New York, Springer-Verlag, 471 p. 


\section{APPENDIX A}

Twin Creek Limestone, Devils Slide Measured Section, Section 24, T. 4 N., R. 3 E. and Section 19, T. 4 N., R. 4 E., SLBL\&M, Morgan County, Utah 


\section{Devils Slide Section}

Date Logged: October 23, 2003

Logged by: Doug Sprinkel, Tom Chidsey

EXPLANATION

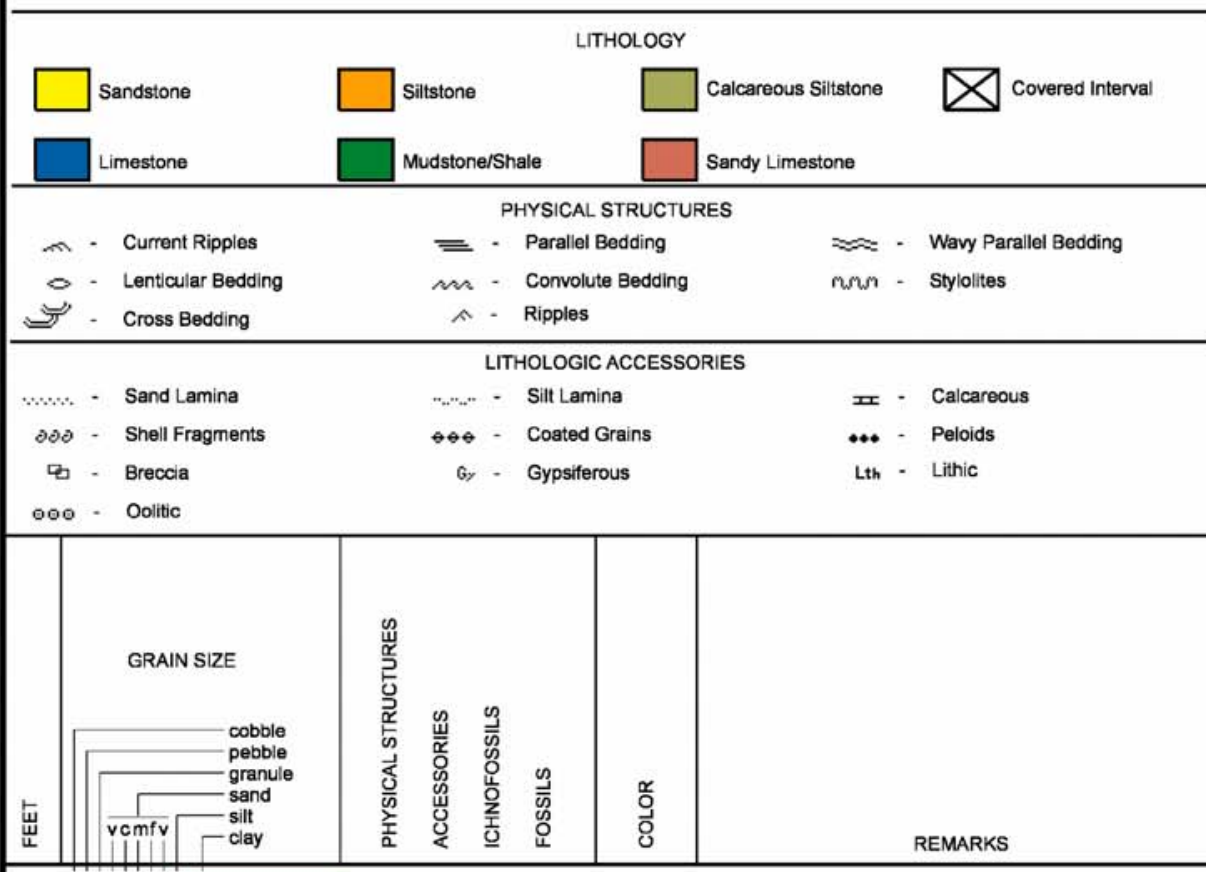

Giraffe Creek Leeds Creek

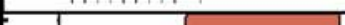
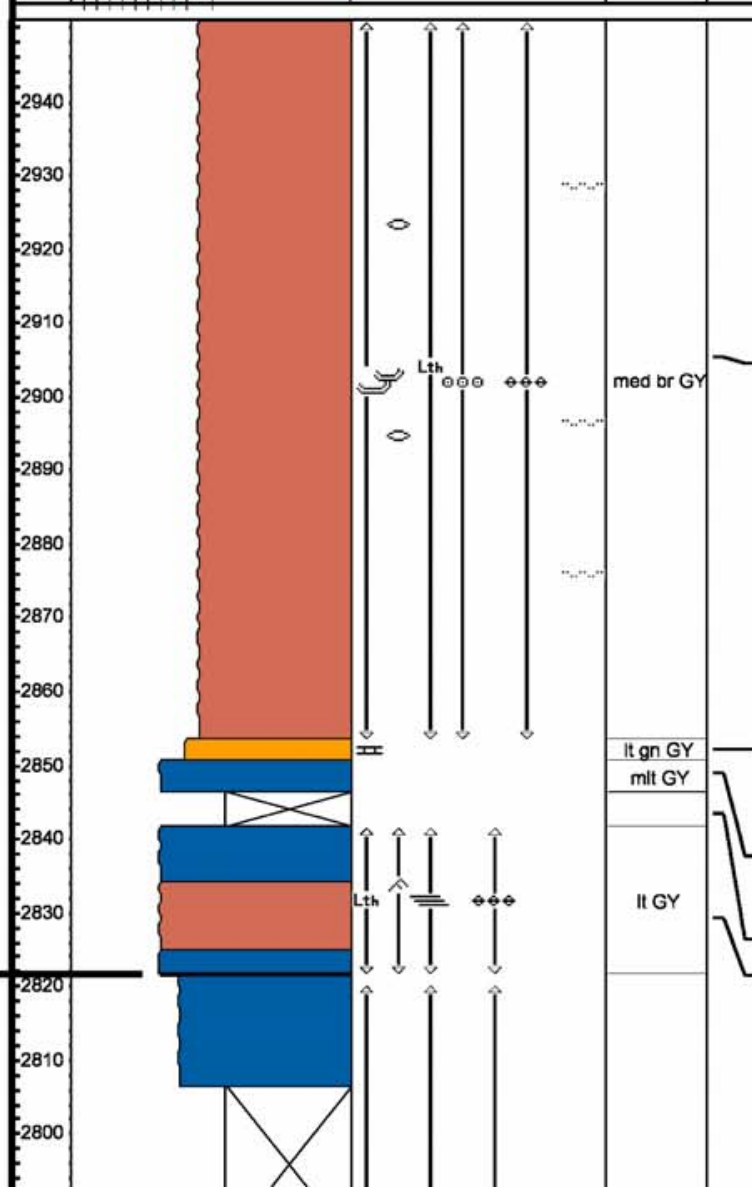

Unit 37: Calcarenite, medium brown gray, weathers light yellow-brown gray, finely crystalline with scattered dark lithic grains, hard, dense, resistant, medium to thick bedded, forms resistant ledges, coated grains, oolites ?, some cross-beds, a few -foot thick silty beds that pinch out (lensoid). rectilinear fracture pattern, top of Giraffe Creek is marked by a bedding-parallel back thrust that places the Boundary Ridge Member on top of the Giraffe Creek Member. End of Section.

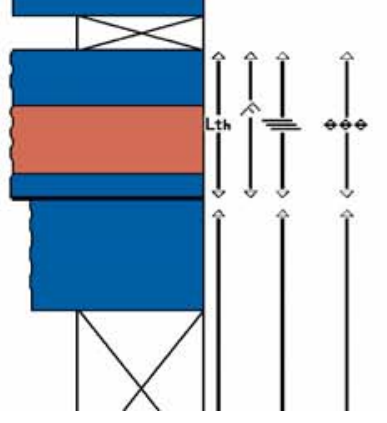

Unit 36: Siltstone, light green gray, calcareous, contains a little clay, very thin bedded, firm but non resistant with thin interbeds of more resistant limestone similar to unit 35 limestone.

Unit 35: Limestone, light to medium gray, fine to medium crystalline, sandy, thin bedded with thin interbeds of fissle siltstone, moderately resistan

- Unit 34: Covered interval, but similar to unit 36

Unit 33: Base of Giraffe Creek Member, contact with Leeds Creek Member is sharp at base of first thick limestone bed, calcarenite, light gray on fresh surfaces, yellow-brown on weathered surfaces, fine to medium grained, a few scattered lithic grains, quartz and iron-coated quartz grains, dense, hard, forms resistant ledges, medium to thick bedded, current npples some vugs, flat and parallel to bedding, top has interference ripples. 

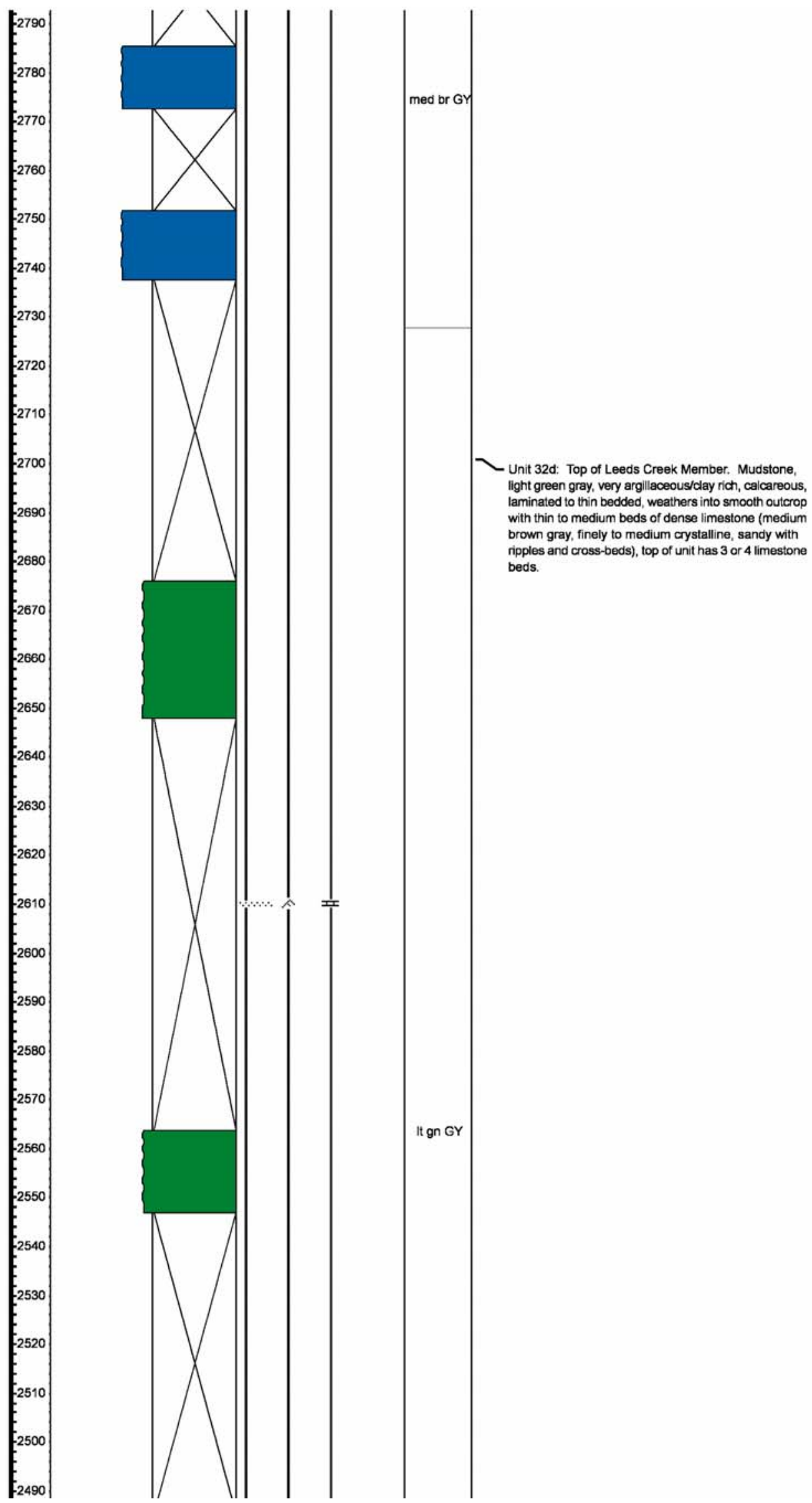
beds. 


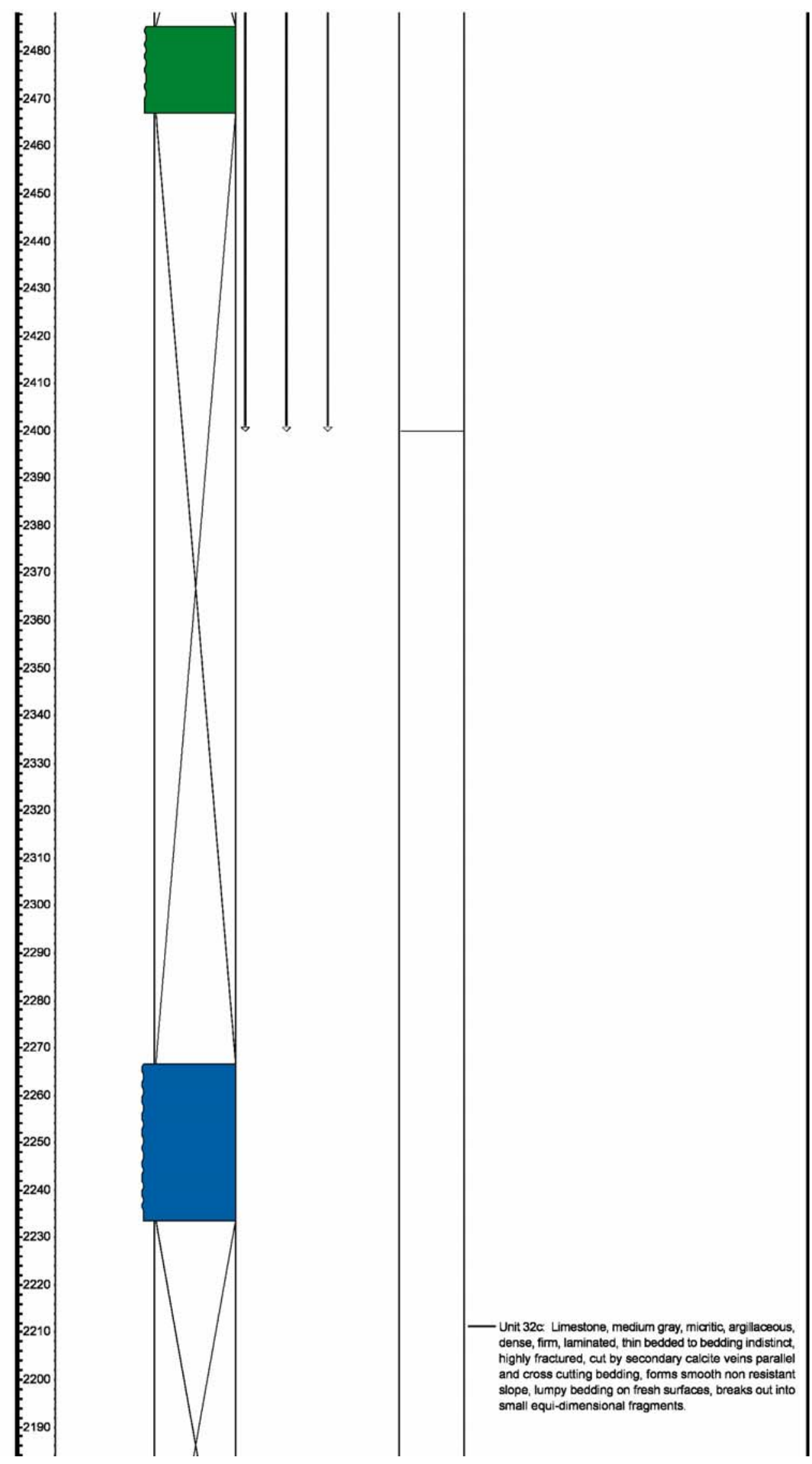




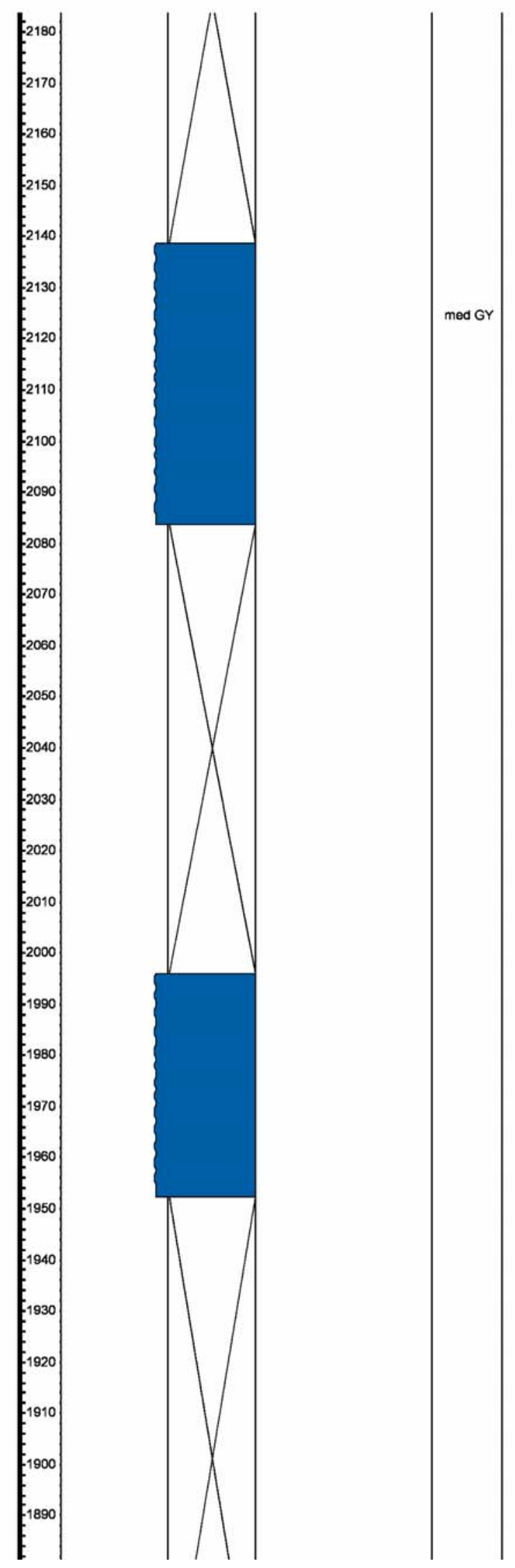



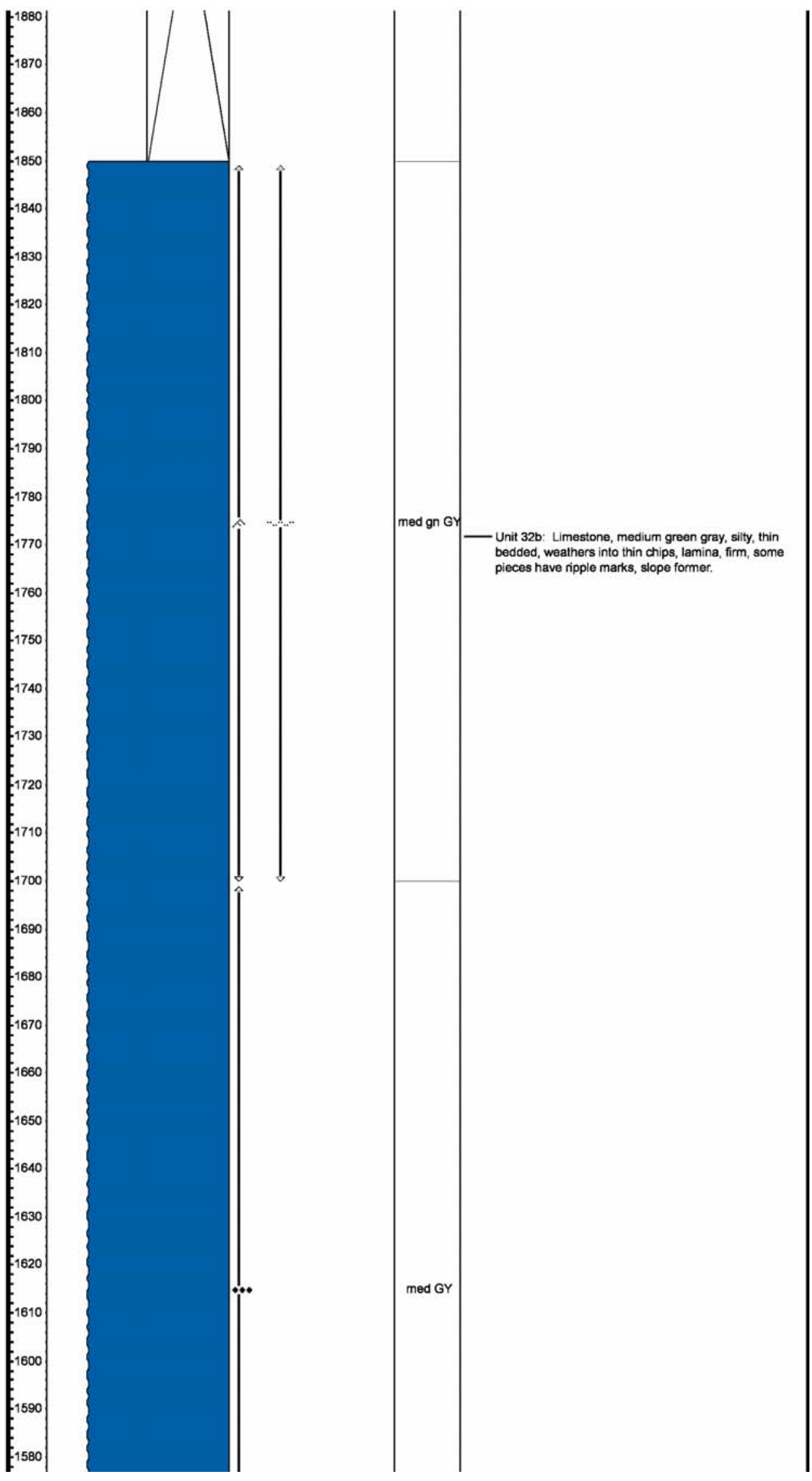

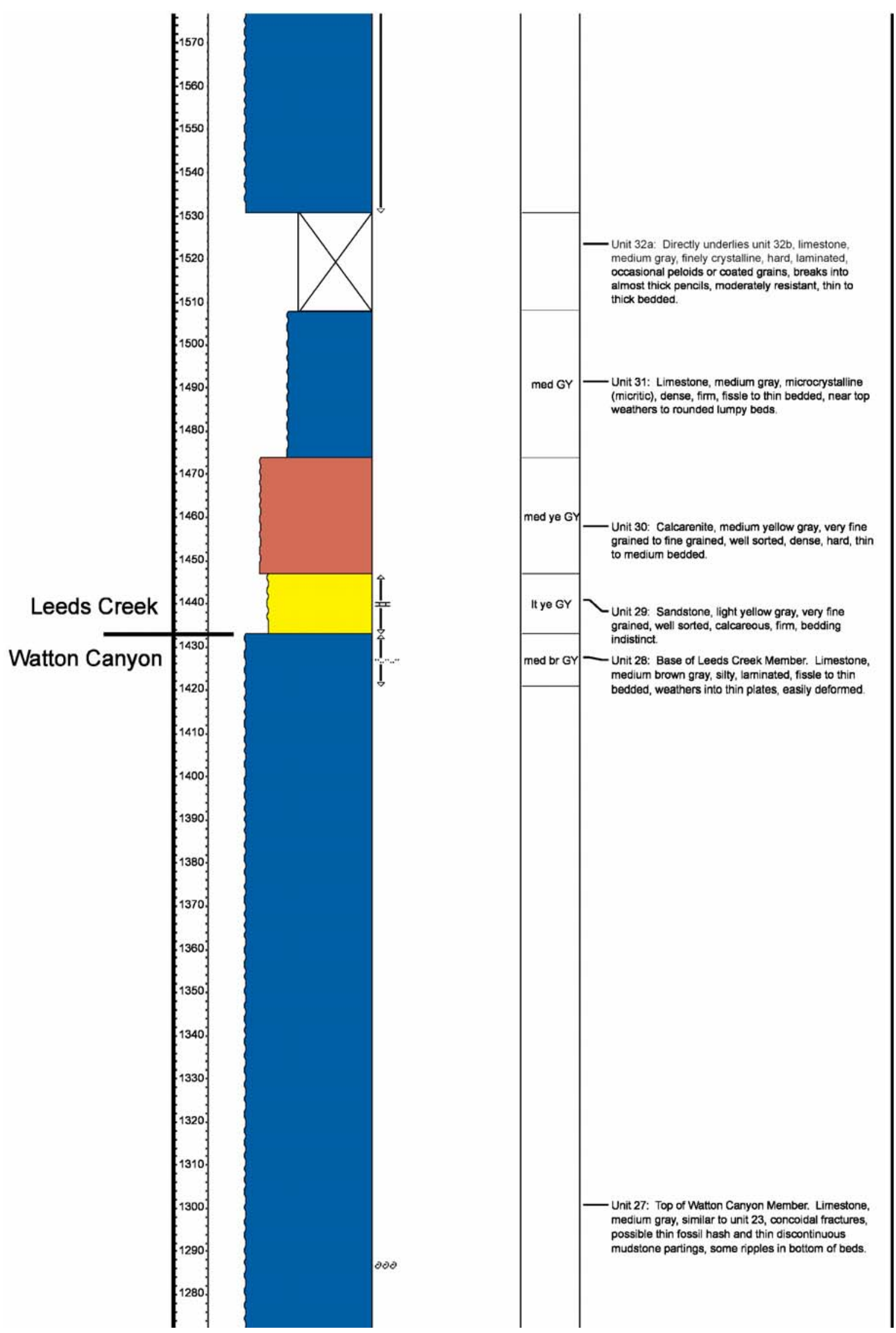

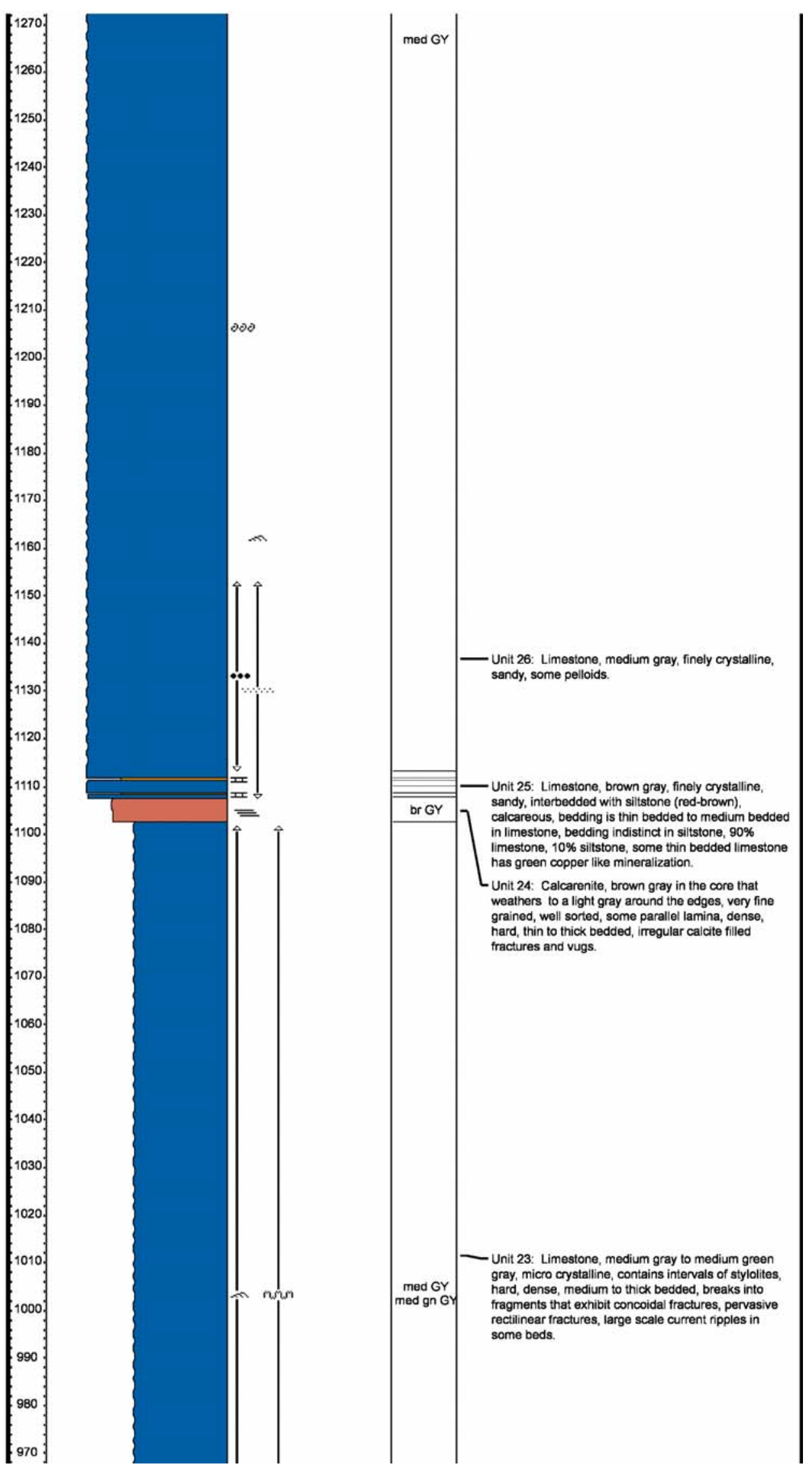


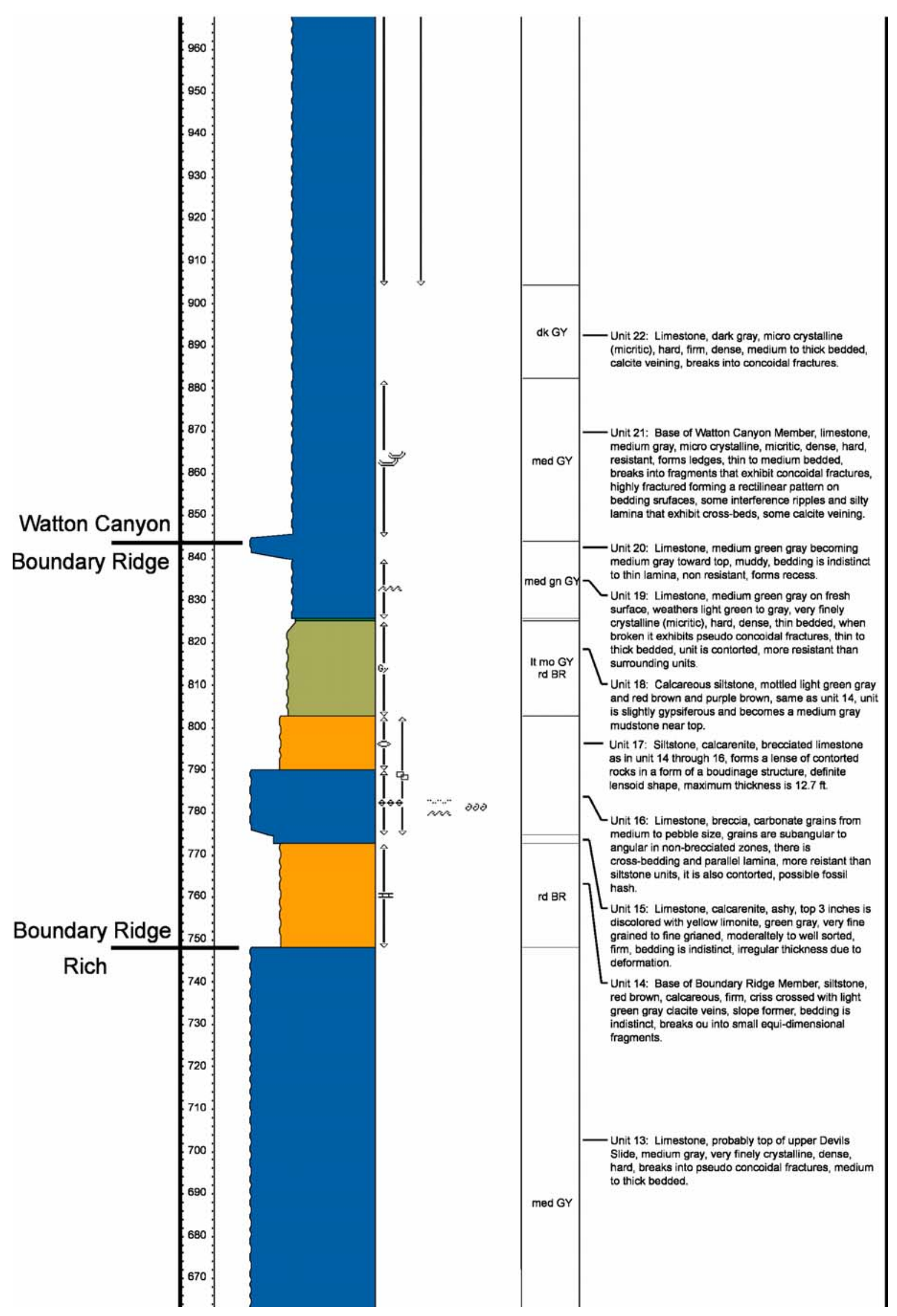



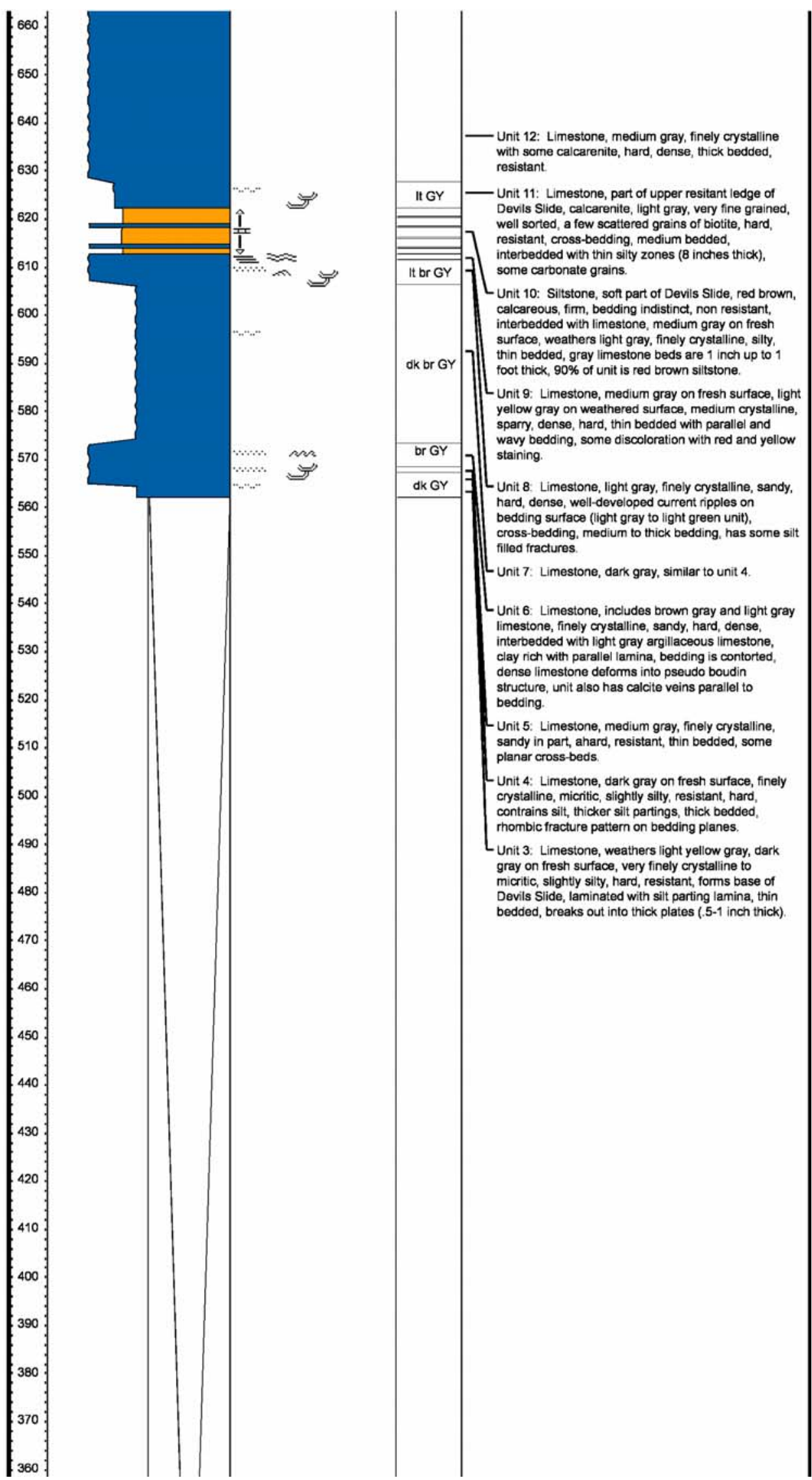

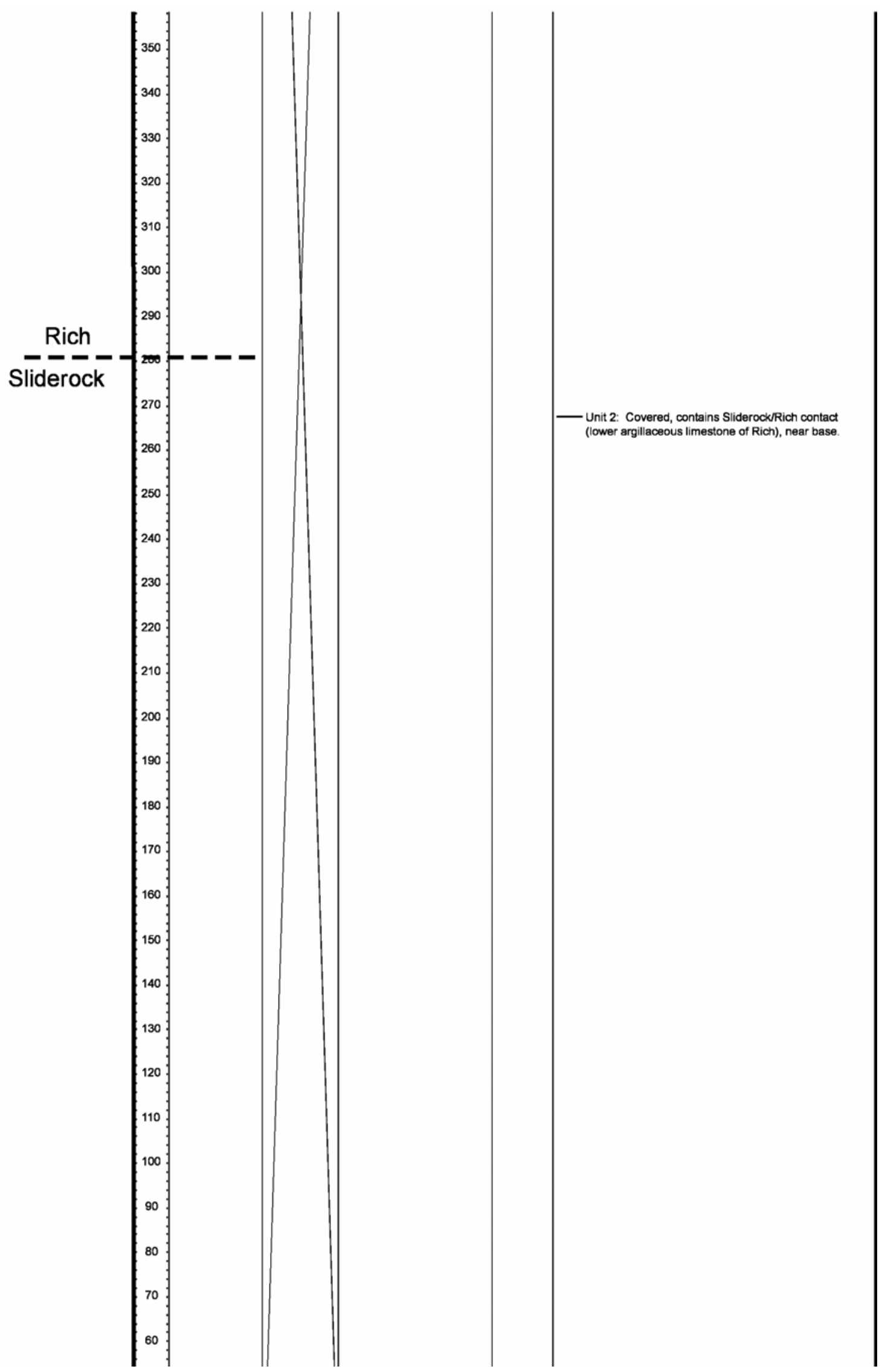


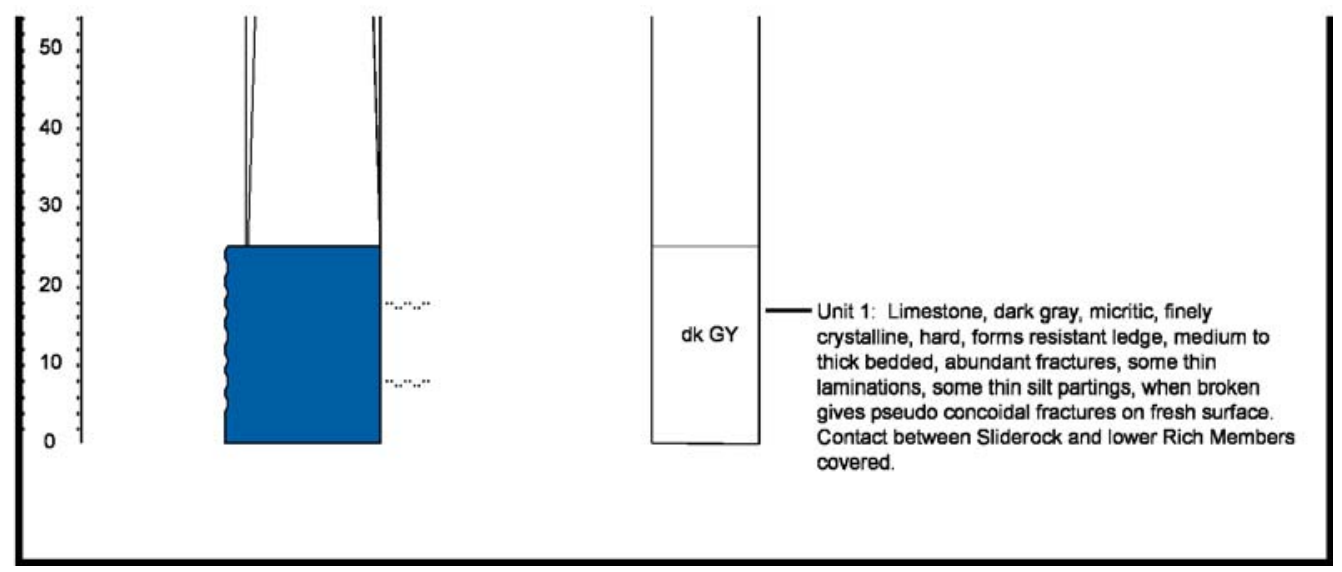




\section{APPENDIX B}

\section{Twin Creek Limestone, Peoa Measured Section, Section 14, T. 1 S., R. 5 E., SLBL\&M, Summit County, Utah}




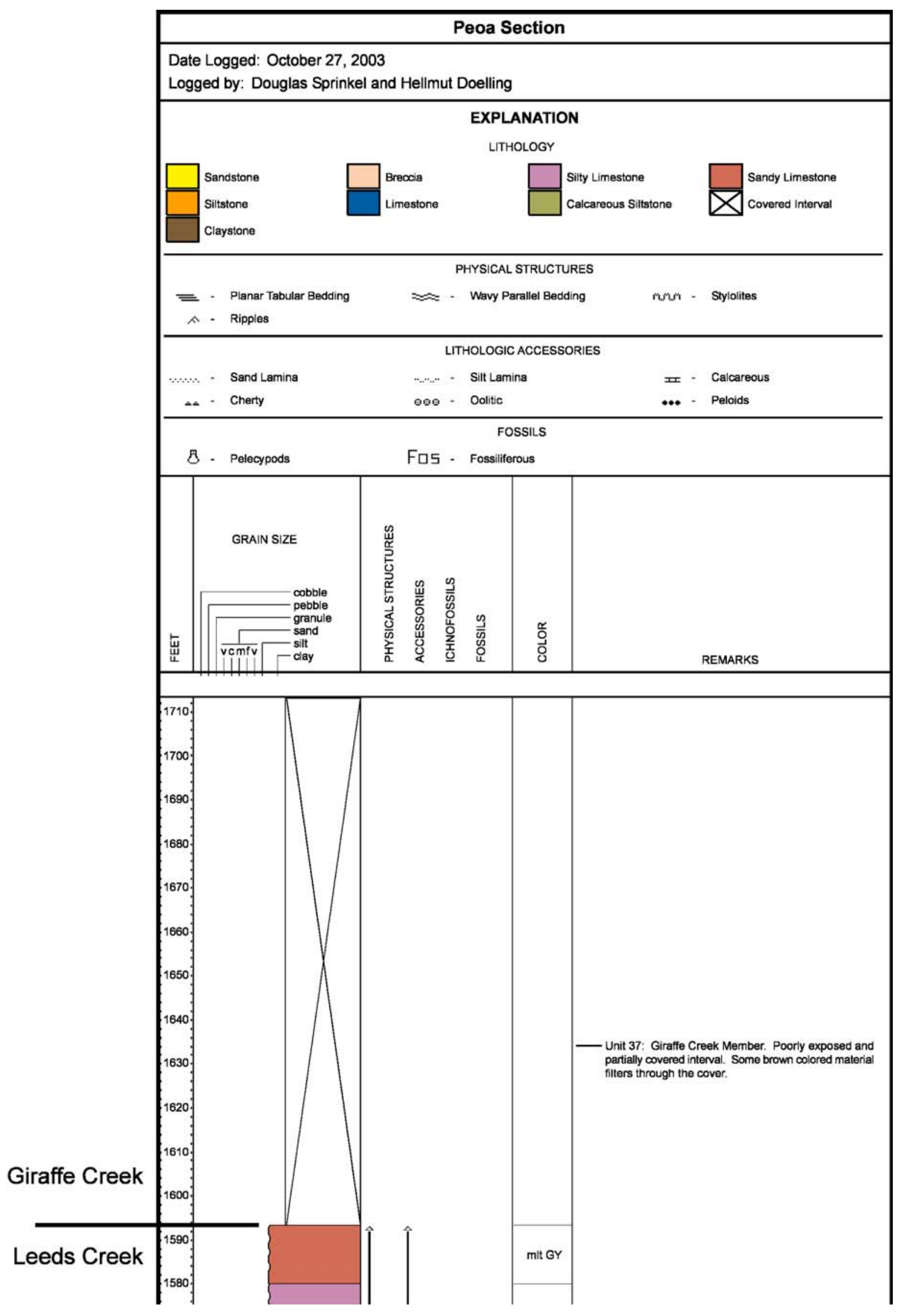



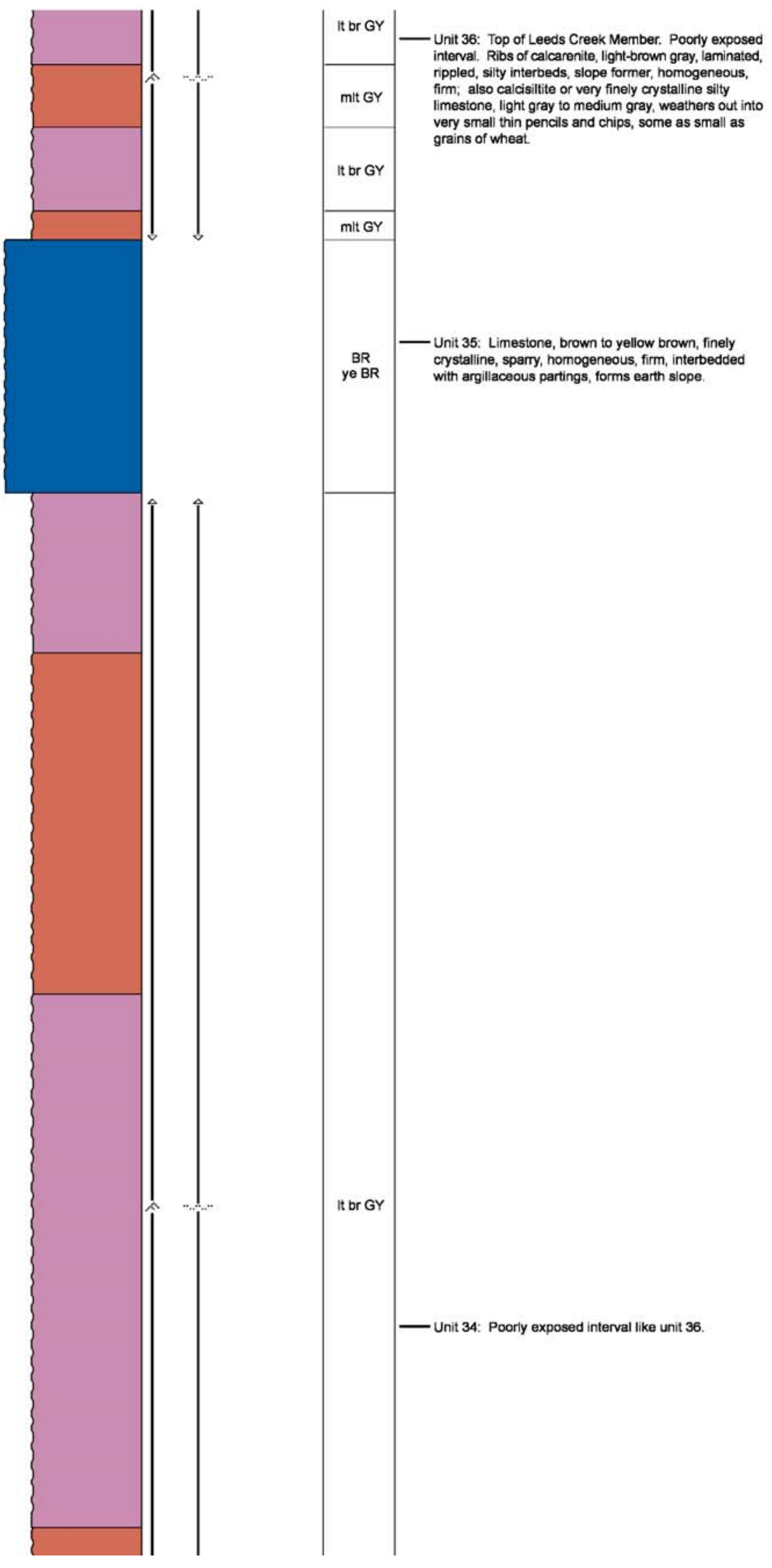
with argillaceous partings, forms earth slope.

- Unit 34: Poorly exposed interval like unit 36. 


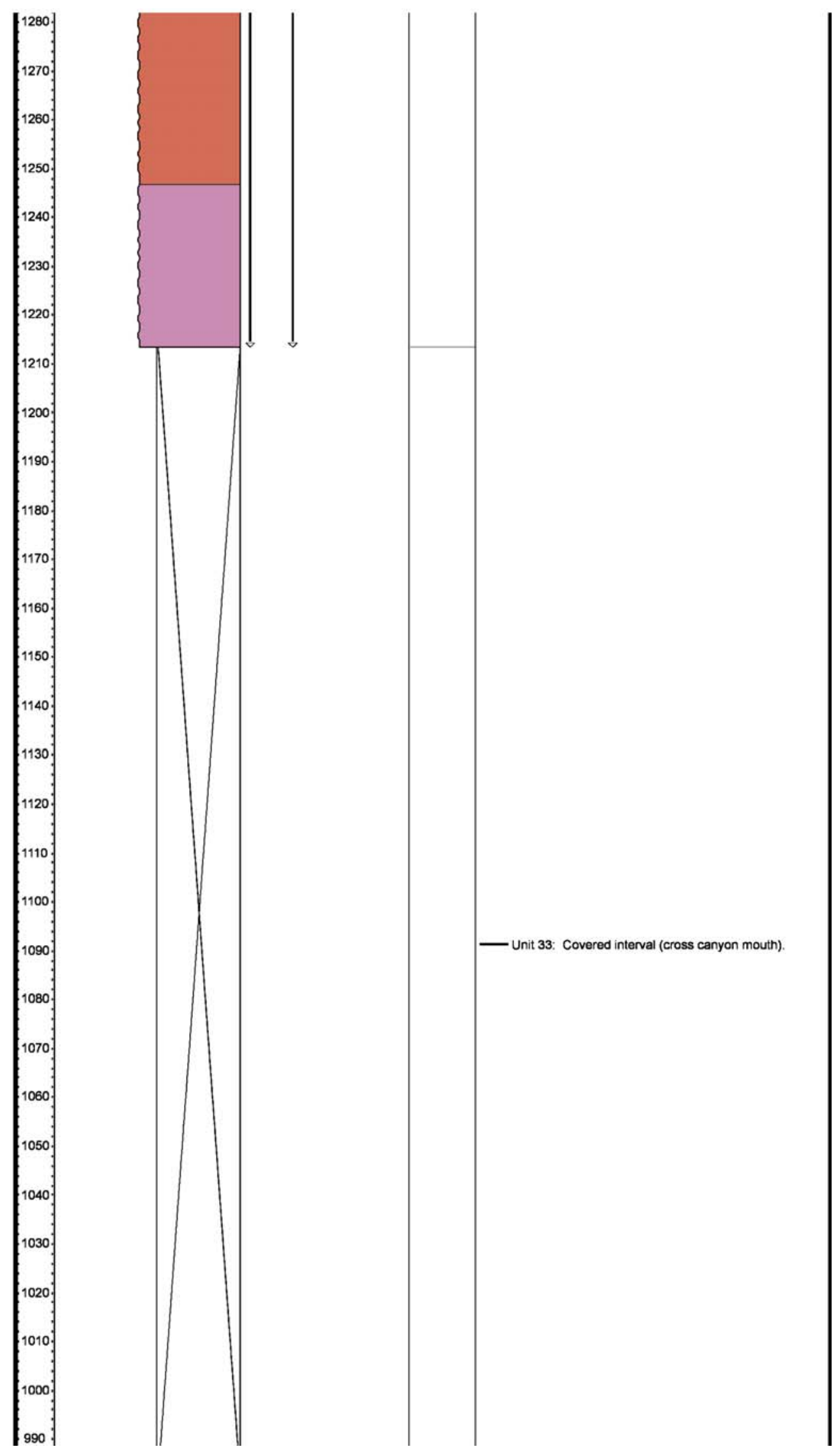




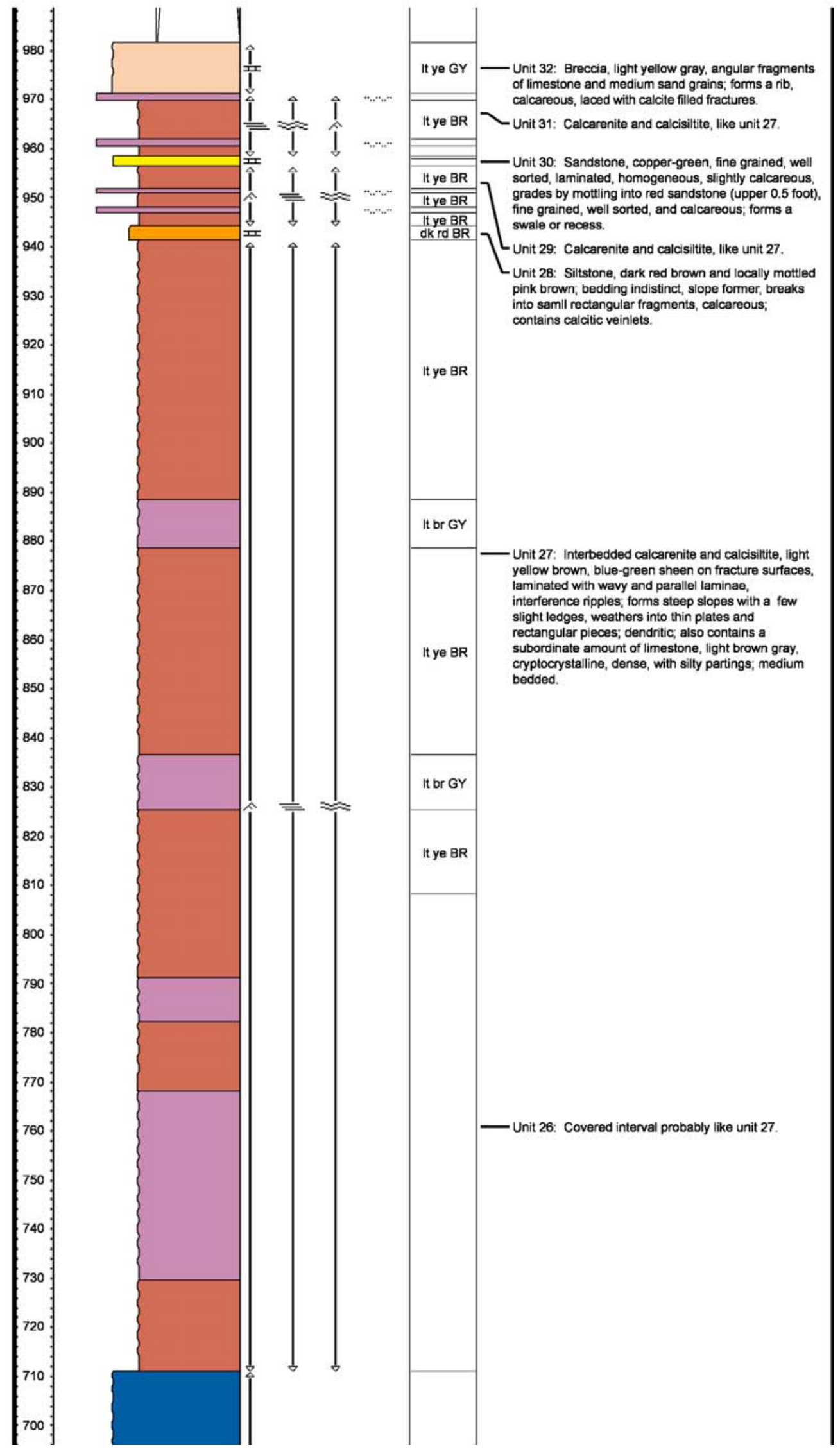



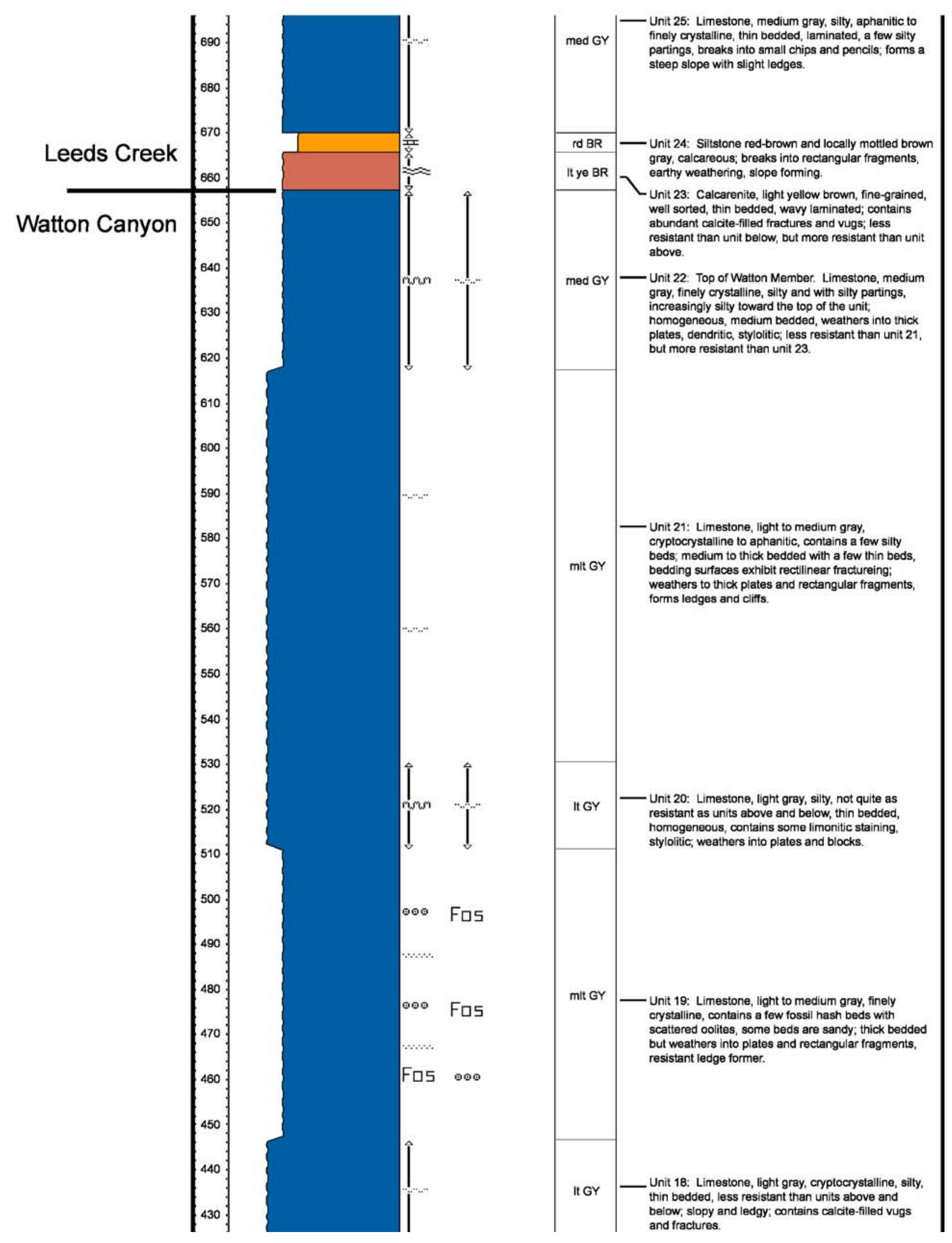


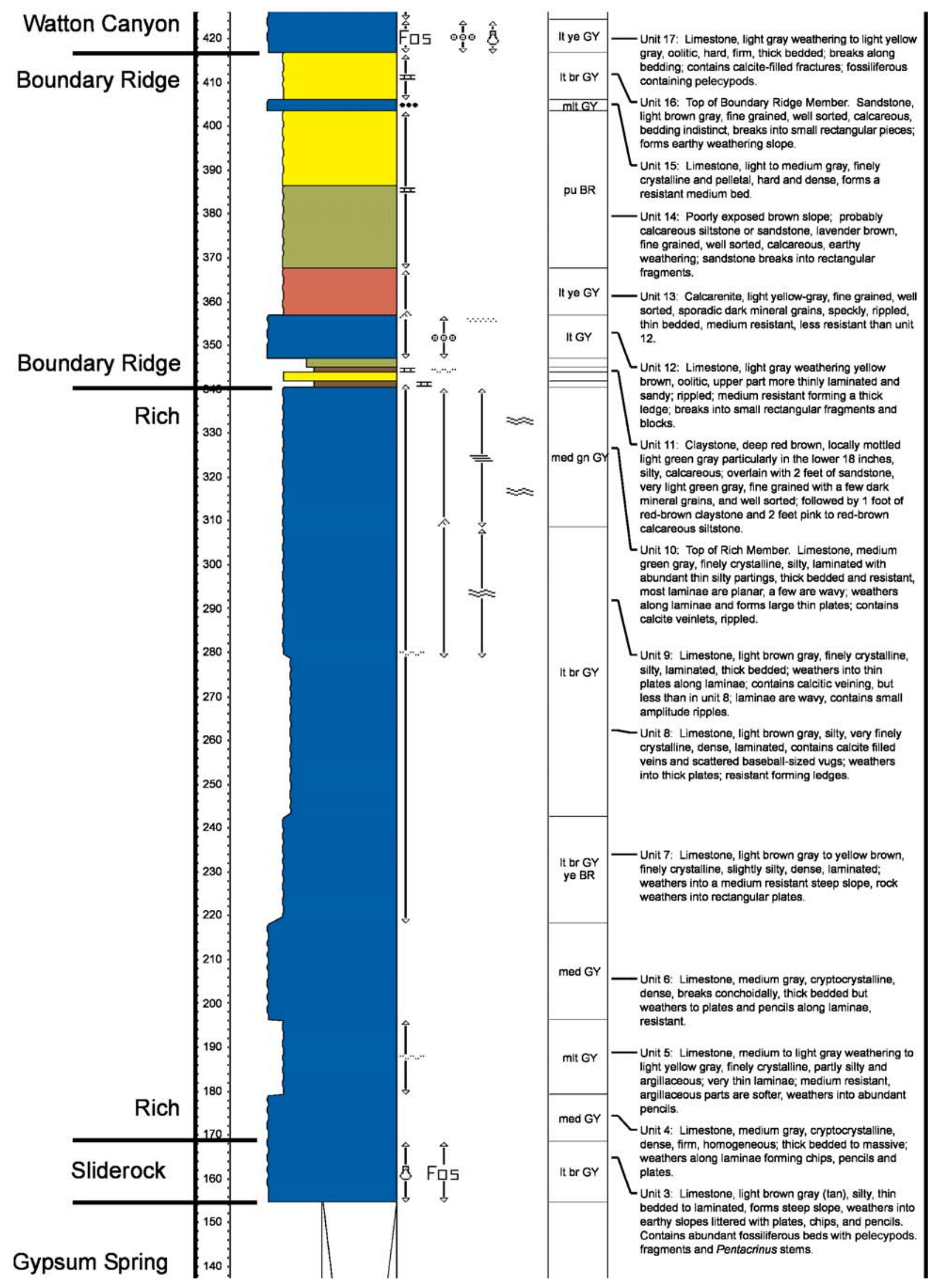



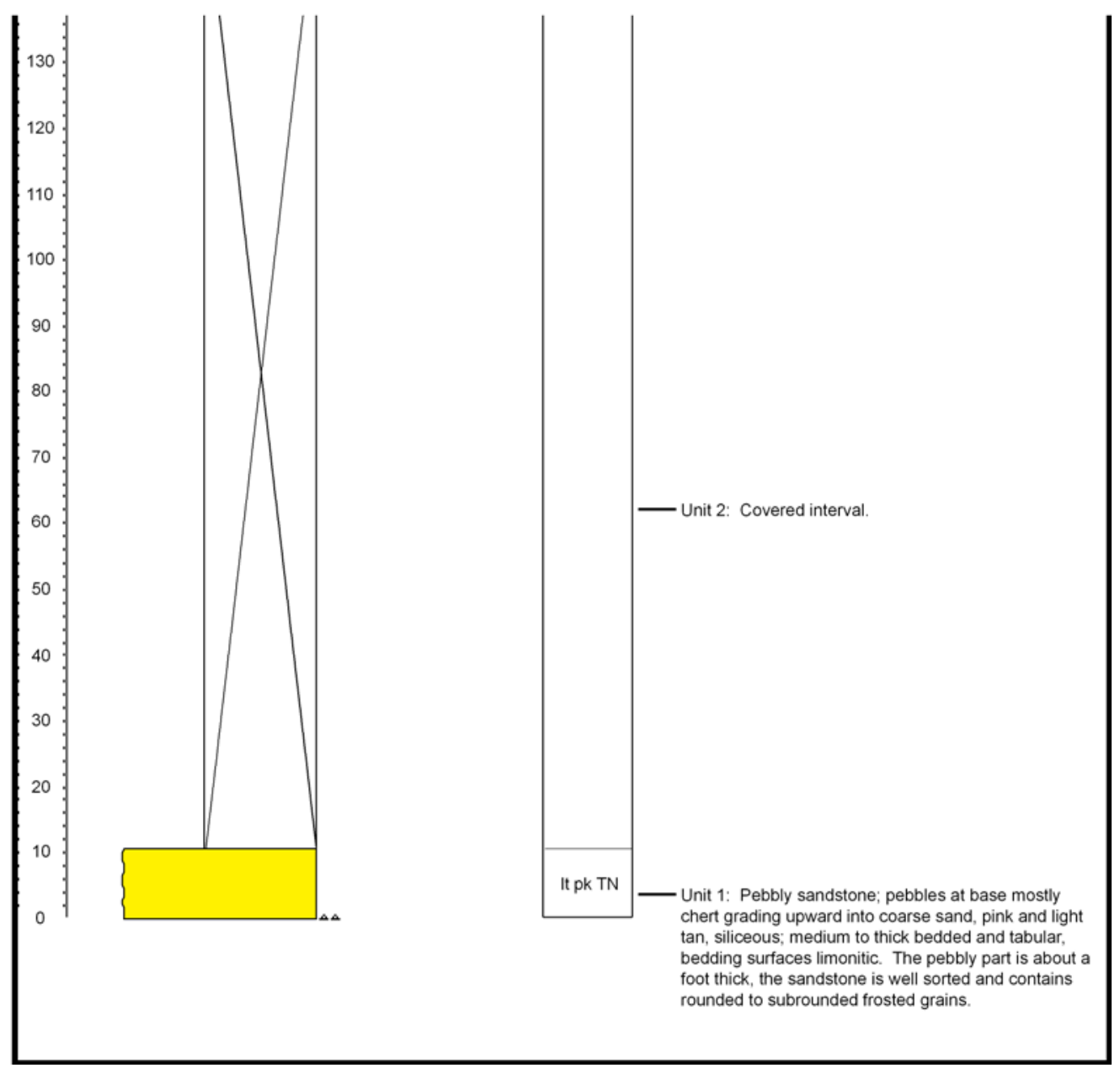